\title{
Reproductive effects of lumpy skin disease virus in cattle
}

Henry (C H) Annandale

2020 


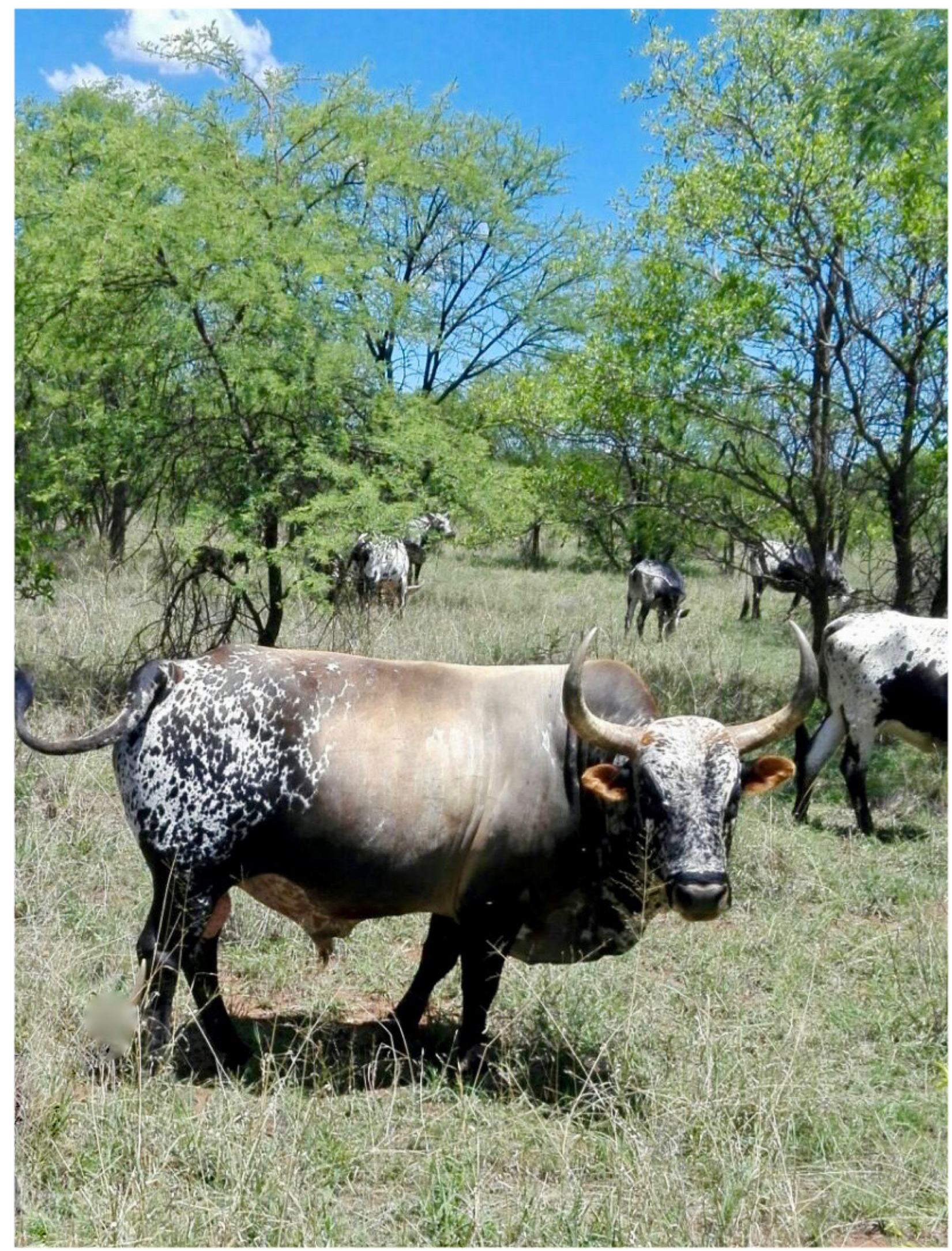


Reproductive effects of lumpy skin disease virus in cattle

Henry (C H) Annandale, 2020

Thesis - Universiteit Utrecht

ISBN: 978-94-640-2362-6 


\title{
Reproductive effects of lumpy skin disease virus in cattle
}

\section{De effecten van lumpy skin disease virus op de voortplanting bij runderen}

\author{
(met een samenvatting in het Nederlands)
}

\section{Proefschrift}

\author{
ter verkrijging van de graad van doctor aan de \\ Universiteit Utrecht \\ op gezag van de \\ rector magnificus, prof.dr. H.R.B.M. Kummeling, \\ ingevolge het besluit van het college voor promoties \\ in het openbaar te verdedigen op
}

maandag 6 juli 2020 des middags te 4.15 uur

door

\section{Cornelius Henry Annandale}

geboren op 23 november 1974

te Pretoria, Zuid-Afrika 


\section{Promotoren:}

Prof. dr. T.A.E. Stout

Prof. dr. E.H. Venter 


\section{Contents}

Chapter 1 General introduction...................................................11

1.1 Historical perspective..................................................................................... 12

1.2 The importance of Lumpy skin disease virus in cattle production .................. 12

1.3 Personal perspective and research goals .................................................... 14

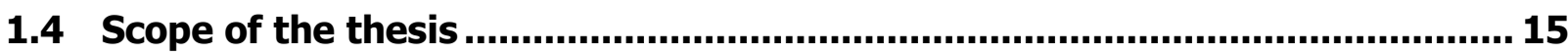

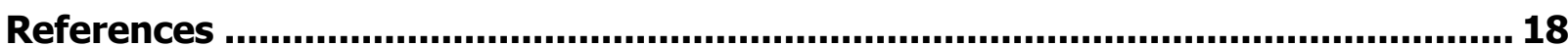

Chapter 2 Sites of persistence of lumpy skin disease virus in the genital tract of experimentally infected bulls..........................20

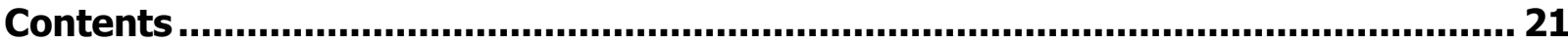

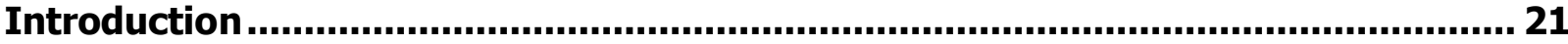

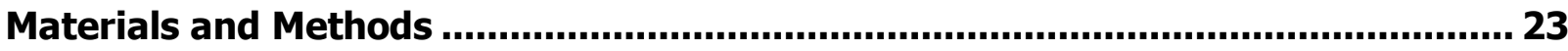

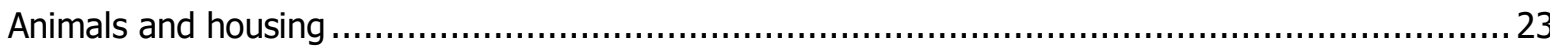

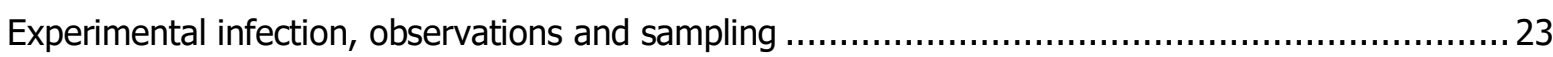

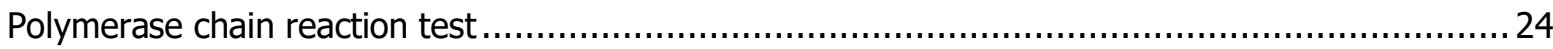

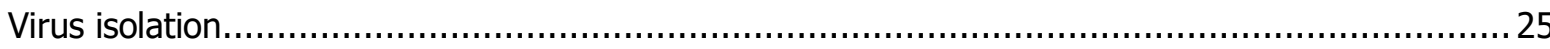

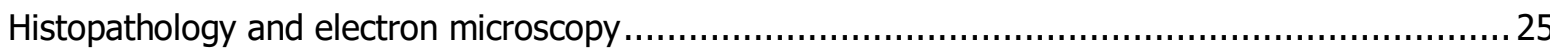

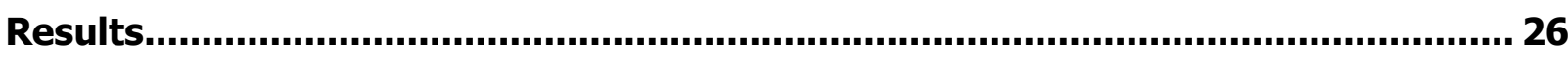

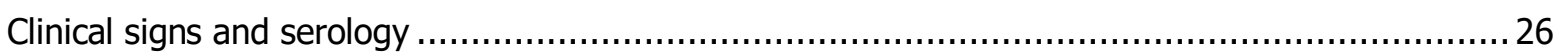

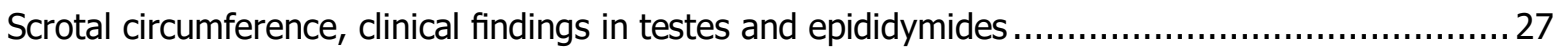

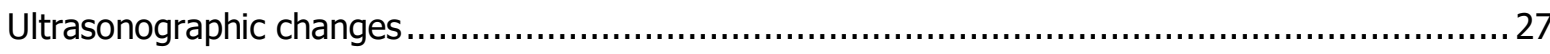

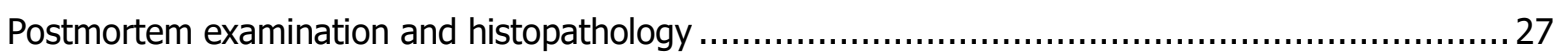

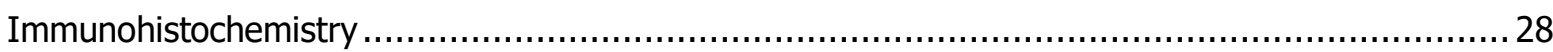

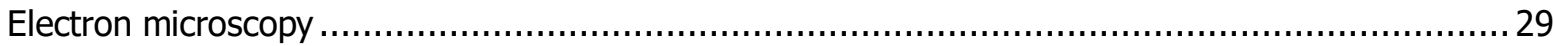

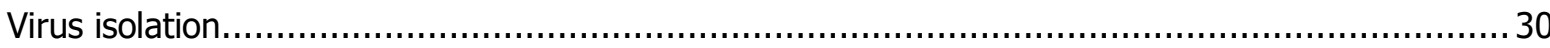

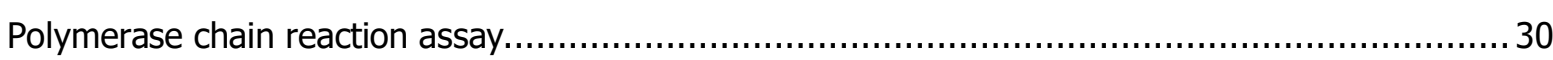

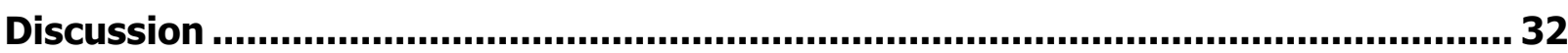

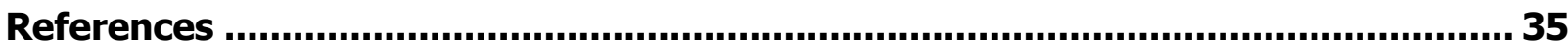

Chapter 3 Seminal transmission of lumpy skin disease virus in heifers ....................................................................................37

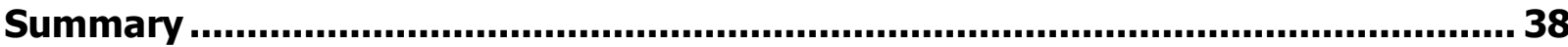

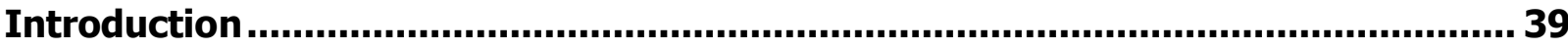

Materials and Methods .................................................................................. 41 


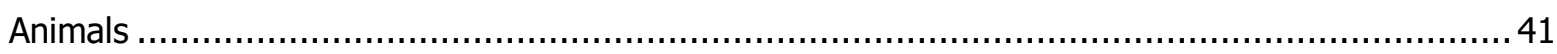

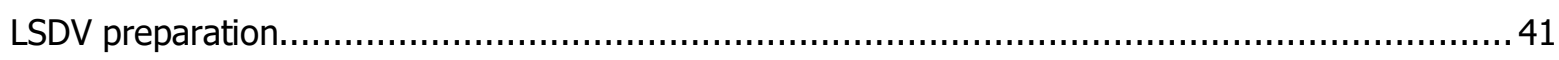

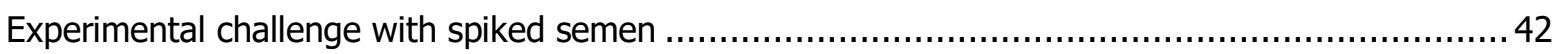

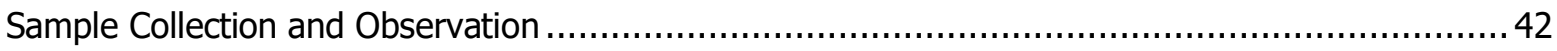

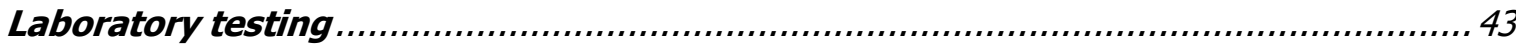

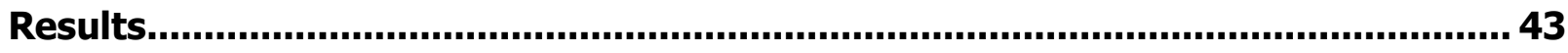

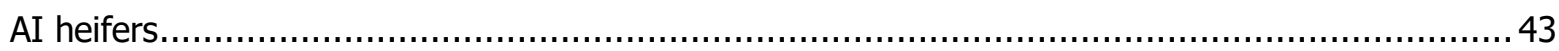

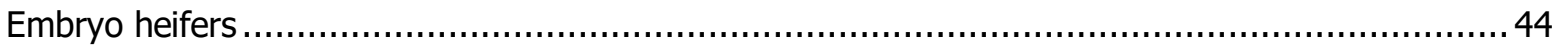

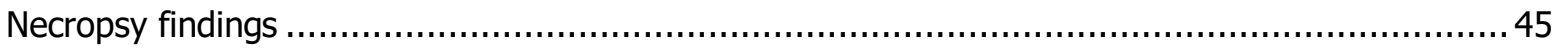

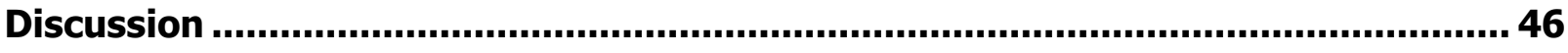

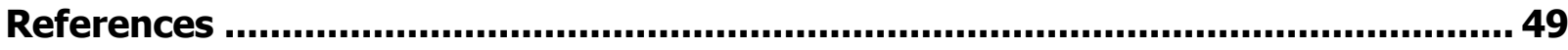

Chapter 4 Effect of using frozen-thawed bovine semen contaminated with lumpy skin disease virus on in vitro embryo production...53

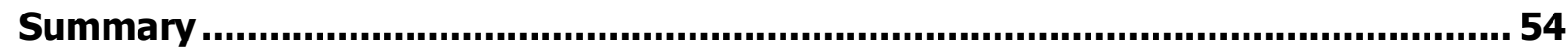

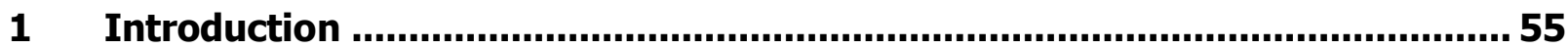

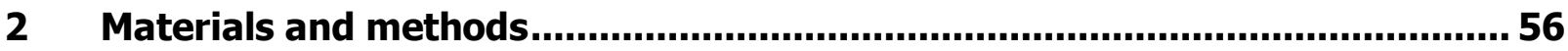

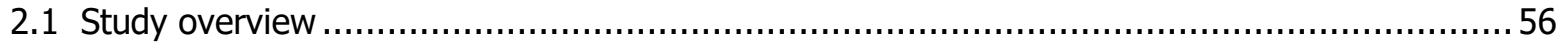

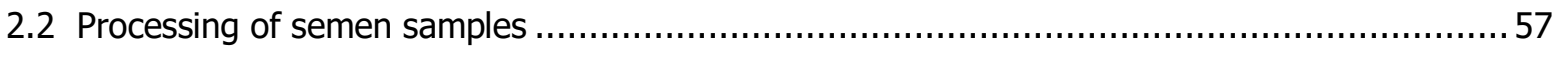

2.3 Semen preparation for in vitro fertilization......................................................... 58

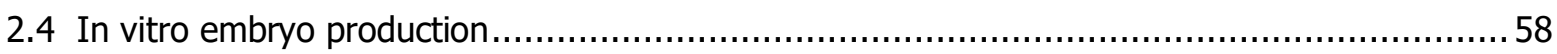

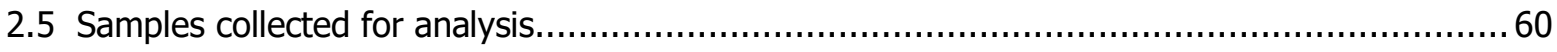

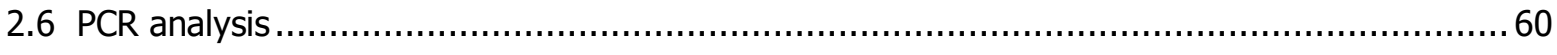

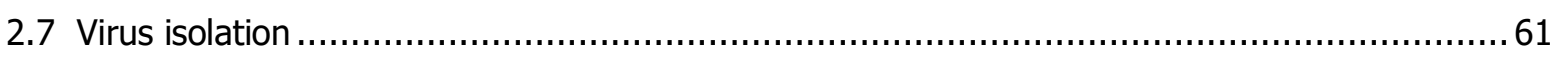

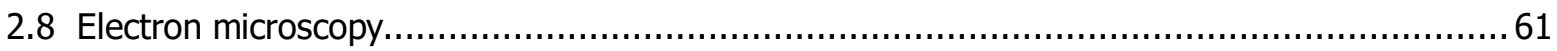

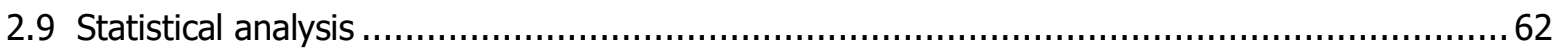

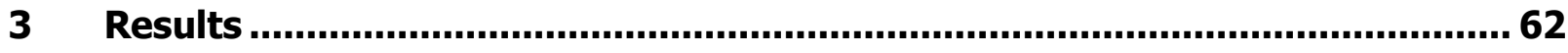

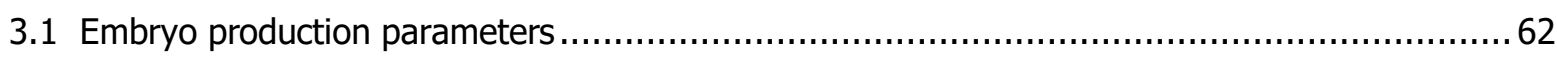

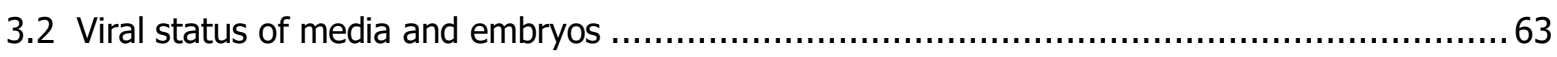

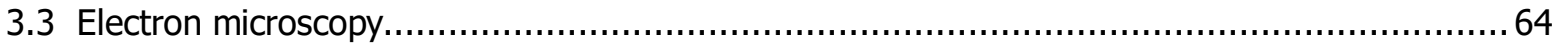

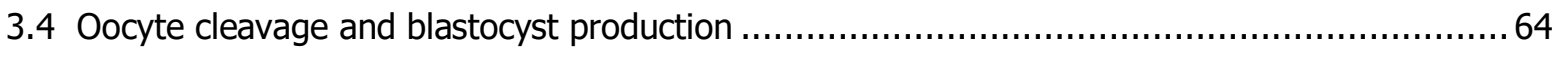

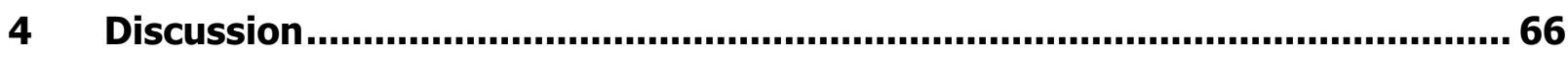

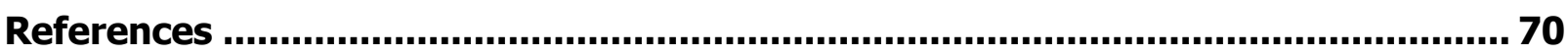

Chapter 5 Effect of semen processing methods on lumpy skin disease virus status in cryopreserved bull semen ................................74

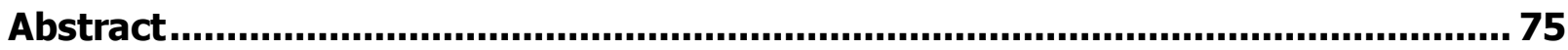

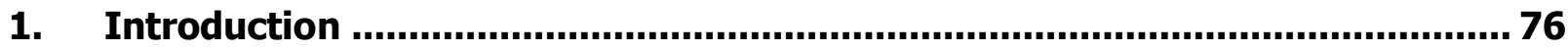

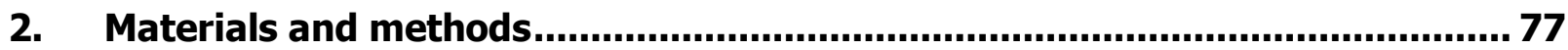

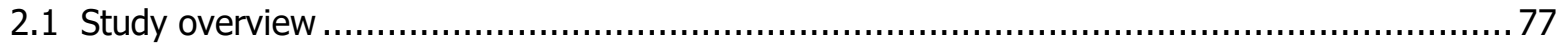

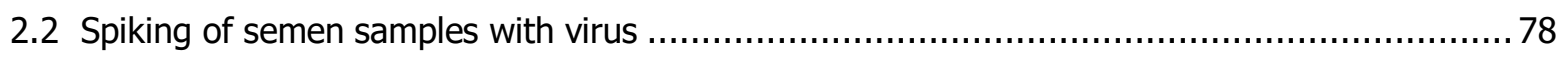




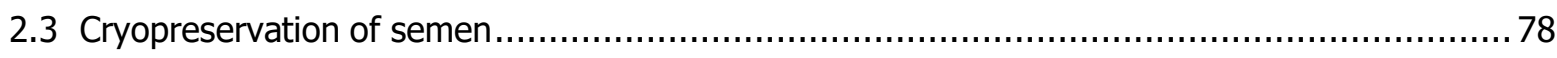

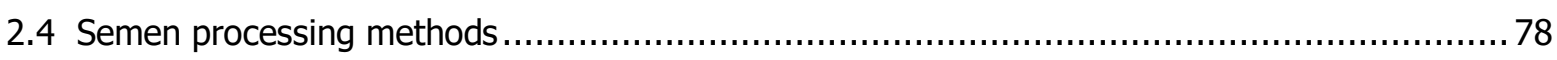

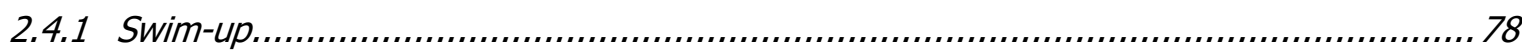

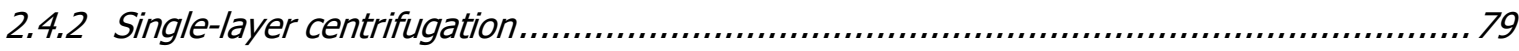

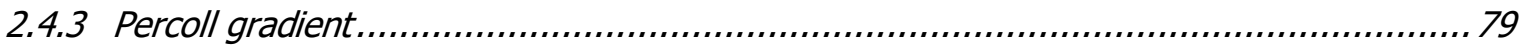

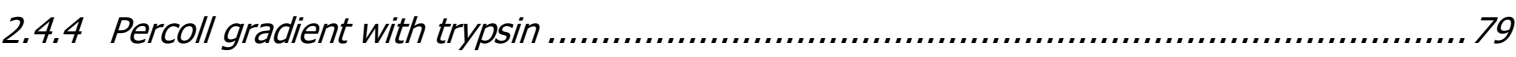

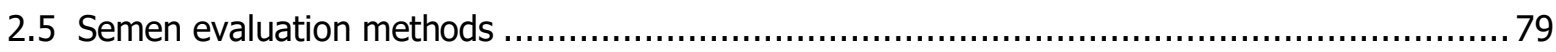

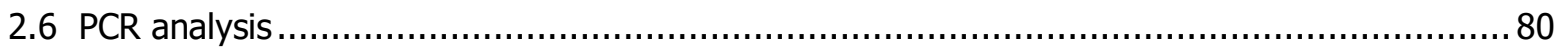

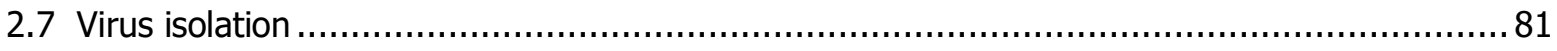

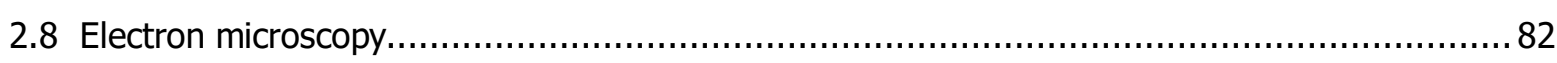

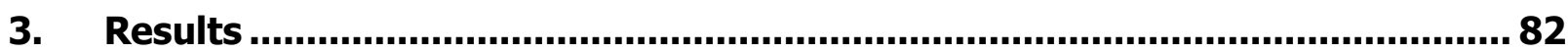

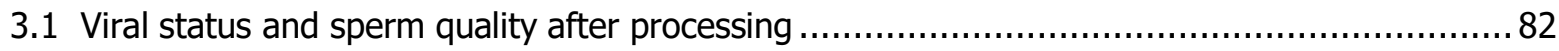

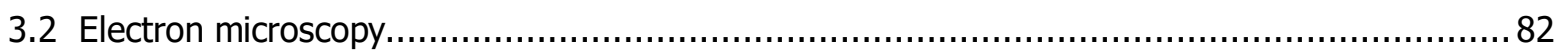

4. Discussion................................................................................................ 83

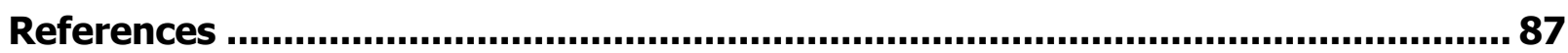

Chapter 6 Absence of lumpy skin disease virus in semen of vaccinated bulls following vaccination and subsequent experimental infection ...........................................................91

Abstract....................................................................................................... 92

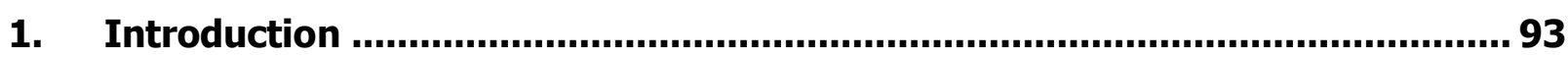

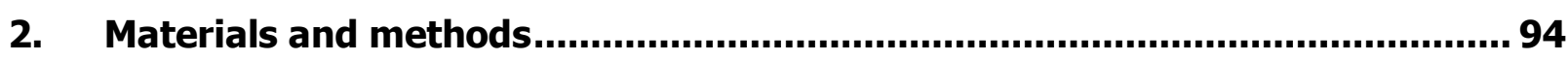

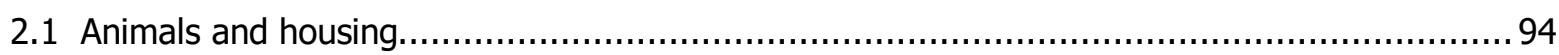

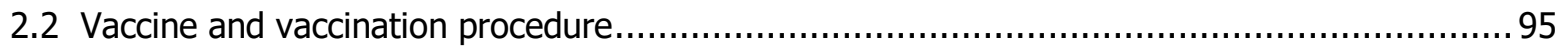

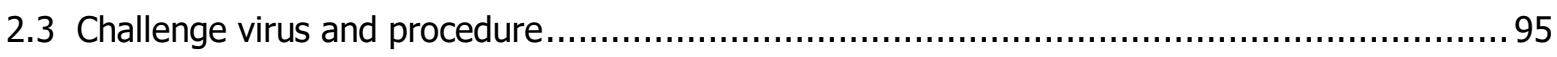

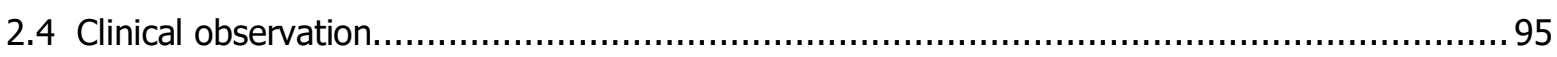

2.5 Blood sampling and semen collection................................................................... 95

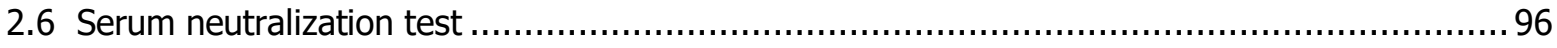

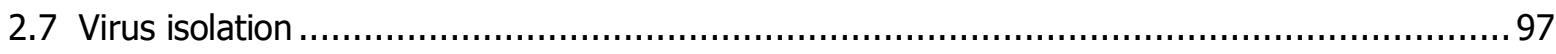

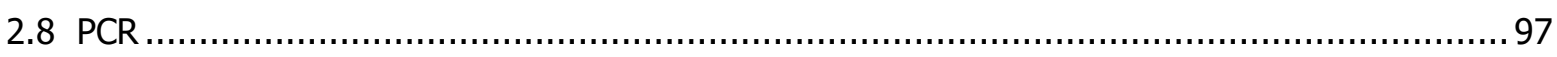

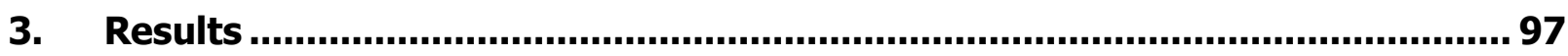

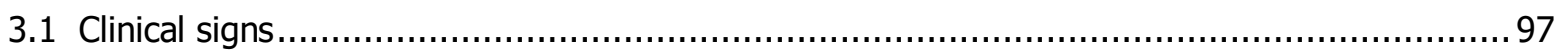

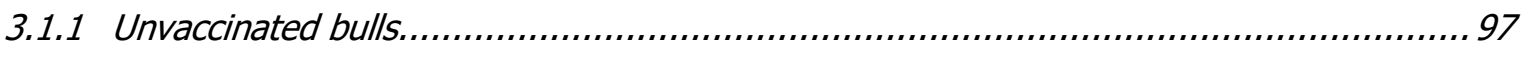

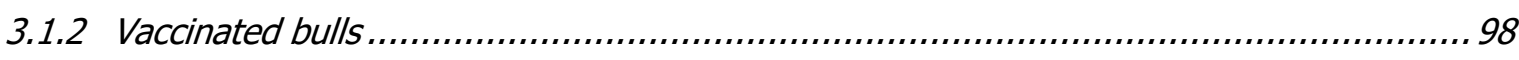

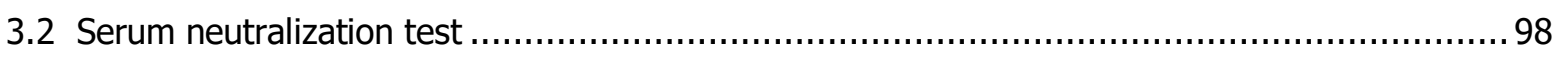

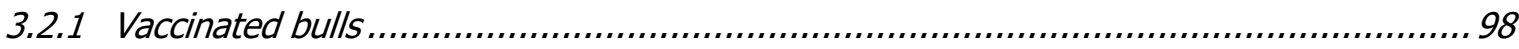

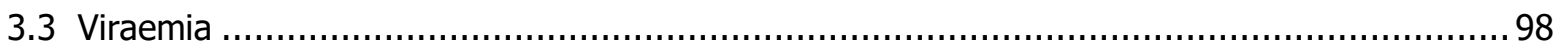

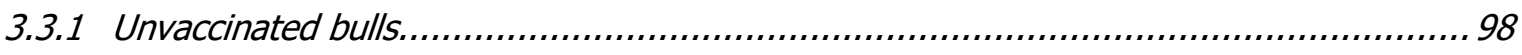

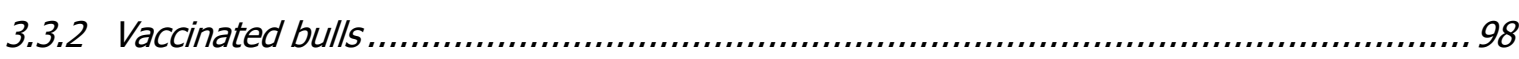

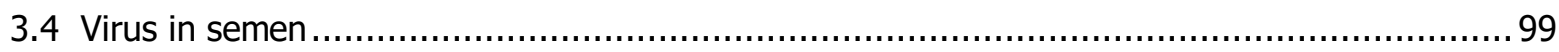

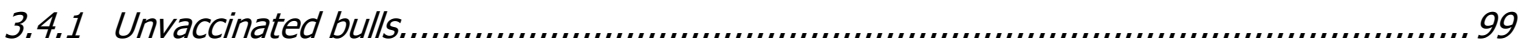


4. Discussion .......................................................................................... 100

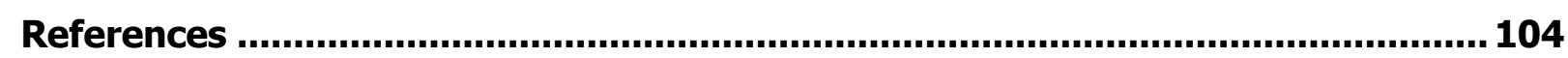

Chapter 7 Summarising discussion ..........................................107

7.1. Importance of LSD in cattle health, reproduction and trade...................... 108

7.2. The effect of LSDV viral dose............................................................ 112

7.3. Clinical syndromes associated with LSDV infection ................................113

7.4. Limitations and future research areas................................................ 115

7.5. Recommendations...................................................................................... 116

7.6 References ..................................................................................... 118

Chapter $8 \quad$ Nederlandse samevatting ........................................120

8.1 Het belang van LSD in de gezondheid, reproductie en handel van runderen ....

8.2 Het effect van de virale dosis LSDV ..................................................... 125

8.3 Klinische syndromen geassocieerd met LSDV-infectie ................................ 126

8.4 Beperkingen en toekomstige onderzoeksgebieden ................................ 128

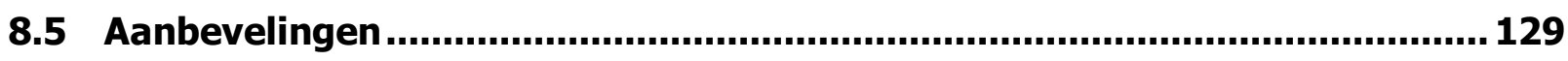

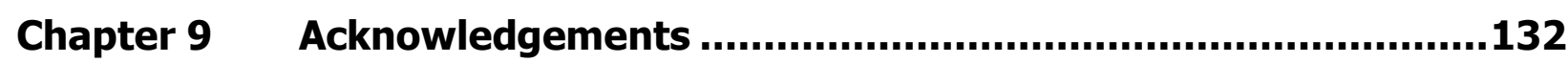

Chapter 10 Curriculum vitae...........................................................136 


$$
1
$$




\section{Chapter 1}

General introduction 


\subsection{Historical perspective}

In many respects, the end of the $19^{\text {th }}$ and early parts of the $20^{\text {th }}$ century, represented a golden age for veterinary science in southern Africa. The iconic picture of Sir Arnold Theiler surrounded by cattle carcasses during a Rinderpest epidemic, conjured up the idea of exotic diseases plaguing man and beast in Africa, and with African Horse Sickness, Bluetongue, Rift Valley Fever and African Swine Fever becoming identified and described, this reputation solidified. The presence of these diseases, along with the many poisonous plants that were found in the region, led to sustained scientific efforts that made significant inroads into our understanding of animal pathogens, how they interact with their hosts and what methods of control can be applied to ensure an environment in which livestock farming could be pursued productively and profitably.

Another typical African animal disease, characterised by lameness, leg swelling, extensive skin nodules and lymphadenopathy with severe loss of condition and common secondary complications, was first described during an outbreak in Zambia in 1929, and the causative agent, lumpy skin disease virus (LSDV), a Capripoxvirus, was isolated for the first time in 1944, in South Africa [1, 2]. The disease, originally known as Ngamiland cattle disease when identified in the Bechuanaland protectorate, later became known as Lumpy skin disease (Afr. Knopvelsiekte). It spread through South Africa at a rapid rate, despite the application of control measures [3]. Over approximately the next 75 years, it spread northwards to Central and East Africa to appear sporadically in Egypt and then Israel in the 1980 's. The $21^{\text {st }}$ century however, saw a massive spread of Lumpy skin disease (LSD) into the European Union and as far east as the Balkans and the Russian Federation. This spread and its implication for cattle populations, community livelihoods and economies, has sparked renewed interest in this "neglected disease" [4].

\subsection{The importance of Lumpy skin disease virus in cattle production}

Lumpy skin disease is reported to have a morbidity rate of $5 \%-45 \%$ on affected farms and mortality rates of up to $10 \%$. Its potential for rapid spread was first reported in Bechuanaland and South Africa, and more recently, experienced in the Balkans [5]. It 
has a profound impact especially on resource-poor communities that depend on cattle for their livelihoods to a greater degree than developed communities. This impact is realised through the prolonged debilitation and recovery period, reduced or absent milk production, temporary or permanent infertility, especially of bulls, and extensive hide damage. It may also cause abortion in up to $10 \%$ of pregnant cows that become infected. Within an African context, cattle still serve as important cultural symbols and Lumpy skin disease therefore can also result in social and cultural disruption.

Developed farming systems, on the other hand, are affected by market exclusion as a consequence of movement control and trade restrictions, since Lumpy skin disease is an OIE-listed disease recognised for its ability to cross boundaries. The market exclusion applies to live cattle exports, hides, milk, embryos and semen, but sometimes the OIE regulations are applied indiscriminately to further include meat, gelatin, hooves, horns and casings.

South Africa is an example of a mixed economy, with elements of subsistence, developing and developed market segments. It can therefore experience the full spectrum of deleterious effects of Lumpy skin disease, ranging from lowered production, social and cultural disruption, to trade restrictions on the export of cattle germplasm. In 2018, agriculture accounted for between $2.5 \%-3 \%$ of South Africa's gross domestic product (GDP) of approximately 350 billion USD, and animal products (red meat, poultry and milk being the main contributors) represented $45 \%-50 \%$ of agricultural income. It is therefore clear that animal diseases and their control are of economic importance to South Africa. Moreover, the economic impact of Lumpy skin disease spreading in areas where it was previously thought to be exotic, has been devastating. Veterinary authorities have spent millions of Euro's in control campaigns involving mass vaccination, animal movement control, surveillance systems, treatment costs, compensation for slaughter and enhanced laboratory diagnostic capabilities. Trade restrictions have further contributed to reduced income within the food production sector and, in some cases, have necessitated food import and concomitant costs.

With a projected world population of 10 billion by 2050, food production will need to adapt to be more efficient, while also taking into account consumer concerns about ethics, 
animal welfare and mitigating the environmental impact. A better understanding of animal diseases such as Lumpy skin disease would allow the veterinary team to assist farmers and producers in meeting some of these goals.

\subsection{Personal perspective and research goals}

I was fortunate in that the work presented in this thesis allowed me to combine two enduring passions, theriogenology and infectious diseases. To have been able to do so within the context of the varying socio-economic realities that I faced as a clinician in the Veterinary Academic Hospital of the Faculty of Veterinary Science of the University of Pretoria, enabled tremendous personal growth. It also brought about a profound realisation of the importance of the roles of livestock and livestock diseases in the livelihoods of people.

Weiss [6] first reported that LSDV was excreted in semen for a period of 22 days following experimental infection. Later, Irons [7] found a much longer excretion period of 42 days (as determined by virus isolation) while LSDV DNA could be detected by conventional PCR for up to 159 days. The latter finding initiated this research, with a focus on the nature of the persistent shedding state of LSDV in the semen of bulls. During this time, it became evident that LSDV had become established in Egypt and Israel, with reports of spread to the Middle East. At the time, as is still the case, the exact nature of transmission of LSDV, was undetermined, with conflicting reports about inter alia the role of different insect vectors [8] and climatic conditions [9]. Furthermore, the epidemiological implications of the seminal shedding of LSDV were not known and it therefore followed that further research could benefit the cattle industry by investigating the reproductive effects of LSDV, the potential role of semen and embryos in transmission thereof, and helping to design prudent control measures to mitigate the associated risks.

The format of this thesis largely mirrors the evolution of the research project from an initial focus on the persistent shedding of LSDV in semen, to evaluating the effect of using infected semen to inseminate heifers or produce embryos in vitro and subsequently, to develop methods that could be employed to reduce or eliminate the presence of the virus in semen. The sequence of the chapters that compose this thesis therefore follows the 
steps of the research process, with findings of earlier chapters incorporated in the research questions investigated in subsequent chapters. The final chapter is a reflection of the work presented, with an analysis of the implications for the management and prevention of the reproductive effects and reproductive transmission of LSDV.

\subsection{Scope of the thesis}

Current research on Lumpy skin disease is primarily focussed on aspects of the immunity following vaccination with attenuated live vaccines and the improvement of diagnostic screening tests such as enzyme-linked immunosorbent assays (ELISA). This is understandable given the rapid spread of the disease in recent years and the control efforts of government veterinary authorities aimed at preventing further spread and thereby protecting national herds and trade. Despite the increased research activity in recent years, clear gaps in our understanding of Lumpy skin disease remain. This applies especially to epidemiological features of the disease, and includes the role of fomites in disease transmission, the level and duration of virus shedding in various bodily fluids, including semen, and the role of subclinically infected animals in disease transmission and as virus reservoirs for infecting potential vectors. From a reproductive perspective, the biosecurity risk associated with the use of LSDV-infected semen and embryos in natural and assisted breeding systems remain undetermined.

The objectives of this work are therefore to define the reproductive effects of LSDV infection in cattle, demonstrate the associated biosecurity risks of semen and embryos and investigate applicable control measures to reduce any proven risks.

Chapter 2 presents experimental results from a study designed to identify and localise the sites of LSDV persistence in the genital tract of bulls, to determine if the virus is present in all fractions of semen and to study the lesions that develop in the genital tract. It therefore describes the experimental infection of bulls with LSDV and the subsequent longitudinal study to observe the general and genitally-specific clinical signs, semen quality parameters and virus shedding in blood, sheath washes, vesicular fluid, supernatant and cell-rich fractions of semen for a period of 28 days post-infection. Bulls still shedding LSDV in semen at this time were deemed to be persistent shedders, and 
euthanised humanely. Studies on euthanised bulls includes necropsy, histopathology (including immunoperoxidase staining of sections), electron microscopy, virus isolation and PCR amplification of viral DNA in affected tissues, in order to localise the virus to specific tissues. The study sheds light on the mechanisms by which LSDV is shed in bull semen and identifies methods for reducing viral contamination of ejaculates at the time of collection. It should also provide valuable information to assist in predicting the likelihood of semen quality recovery in severely affected bulls.

Chapter 3 describes the use of semen spiked with LSDV for artificial insemination (AI) of heifers. This study investigates the biosecurity risk of using LSDV infected semen for AI by studying the clinical signs, virus shedding and immune reaction of inseminated heifers, as well as the viral status of resulting embryos, over a period of approximately 4-weeks.

Chapter 4 investigates the effect of LSDV dose in semen on in vitro embryo production (IVEP) parameters, and the biosecurity risk posed by IVP embryos produced using frozenthawed semen contaminated with LSDV. Frozen-thawed semen spiked with low or high doses of LSDV is used to fertilize over 1,000 oocytes and the two groups are compared with a control group with regard to oocyte cleavage, blastocyst formation, and the viral status of media and embryos. Finally, electron microscopy is utilised to establish how the virus associates with embryos.

Chapter $\mathbf{5}$ is an experimental study aimed at evaluating the effects of four different semen processing methods on lumpy skin disease virus status in cryopreserved semen. In this study, semen processing methods that have been used to render semen free from other infectious agents, were evaluated to determine whether they have a similar effect on LSDV introduced at different viral doses to semen, while also evaluating the effects of the processing method on semen quality parameters. Electron microscopy is used to examine the ultrastructural association of virions with spermatozoa.

Chapter 6 evaluates the ability of vaccination with a modified live (Neethling type) vaccine to prevent seminal shedding of LSDV and vaccine virus following experimental infection of bulls, and to determine whether vaccine virus is shed in semen. This study 
also follows the clinical course of Lumpy skin disease in vaccinated bulls as compared to unvaccinated bulls.

Chapter 7 aims to consolidate and discuss the findings of the preceding chapters. It highlights the limitations of the series of studies and identifies areas for future research focus. The chapter concludes with practical recommendations for the control and prevention of the reproductive risks associated with LSDV infection in natural and assisted cattle breeding systems. 


\section{References}

[1] Alexander R A, Plowright W, Haig D A. Cytopathic agents associated with lumpy skin disease of cattle. Bulletin of Epizootic Diseases of Africa. 1957. 489-92.

[2] Babiuk S, Bowden T R, Parkyn G, Dalman B, Manning L, Neufeld J, et al. Quantification of lumpy skin disease virus following experimental infection in cattle. Transboundary and Emerging Diseases. 2008. 55:299-307.

[3] Thomas A D, Mare C V E. Knopvelsiekte. Journal of the South African Veterinary Medical Association. 1945. 16:36-43.

[4] Coetzer J A W, Tuppurainen E, Babiuk S, Wallace D B. Lumpy Skin Disease. In: Coetzer J A W, Thomson G R, MacLachlan N J, Penrith M-L (Eds.), Infectious Diseases of Livestock. www.anipedia.org. Anipedia. 2018.

[5] Zeynalova S, Asadov K, Guliyev F, Vatani M, Aliyev V. Epizootology and molecular diagnosis of lumpy skin disease among livestock in Azerbaijan. Frontiers in Microbiology. 2016. 7.

[6] Weiss K E. Lumpy Skin Disease Virus. Virology Monographs. 1968. 111-31.

[7] Irons P C, Tuppurainen E S M, Venter E H. Excretion of lumpy skin disease virus in bull semen. Theriogenology. 2005. 63:1290-7.

[8] Carn V M, Kitching R P. An investigation of possible routes of transmission of lumpy skin disease virus (Neethling). Epidemiology and Infection. 1995. 114:219-26.

[9] Magori-Cohen R, Louzoun $Y$, Herziger $Y$, Oron E, Arazi A, Tuppurainen E, et al. Mathematical modelling and evaluation of the different routes of transmission of lumpy skin disease virus. Veterinary Research. 2012. 43. 


$$
2
$$




\section{Chapter 2}

\section{Sites of persistence of lumpy skin disease virus in the genital tract of experimentally infected bulls}

\section{H Annandale ${ }^{1}$, P C Irons ${ }^{1}$, V P Bagla ${ }^{2}$, U I Osuagwuh ${ }^{1}$ and E H Venter ${ }^{2}$}

${ }^{1}$ Section Reproduction, Department of Production Animal Studies

${ }^{2}$ Department of Veterinary Tropical Diseases, Faculty of Veterinary Science, University of Pretoria, Onderstepoort, South Africa 


\section{Contents}

The objectives of this work were to determine the site of persistence of lumpy skin disease virus (LSDV) in bulls shedding the virus in semen for a period longer than 28 days, to determine if the virus is present in all fractions of semen and to study lesions that developed in the genital tract. Six serologically negative postpubertal bulls were experimentally infected with a virulent field isolate of LSDV. The polymerase chain reaction (PCR) was performed on sheath washes, vesicular fluid, supernatant and cellrich fractions of semen from day 10 to day 26 postinfection (p.i.). Bulls that were positive by PCR on the whole semen sample collected on day 28 p.i. were slaughtered and tissue samples from their genital tracts submitted for histopathological evaluation, immunoperoxidase staining, virus isolation and PCR. Two of the bulls developed severe lumpy skin disease (LSD) and were found to be shedding viral DNA in their semen on day 28 p.i. Viral DNA was identified in all semen fractions from all bulls, but mostly from the cell-rich fraction and from the severely affected bulls. The PCR assay was positive on postmortem samples of testes and epididymides from the two severely affected bulls. Virus could be recovered from the testes of these two bulls and from the epididymis of one of them. Immunoperoxidase staining was positive for LSDV staining in sections of testes and epididymides exhibiting necrosis. This study suggests that the testis and epididymis are sites of persistence of LSDV in bulls shedding virus in semen for prolonged periods and revealed that viral DNA is present in all fractions of the ejaculate.

\section{Introduction}

Lumpy skin disease virus (LSDV), a member of the genus Capripoxvirus, causes an acute, subacute or chronic disease of cattle, characterized by fever and the formation of multiple firm, circumscribed nodules in the skin of affected animals and necrotic plaques in the mucous membranes, as well as generalized lymphadenopathy (Coetzer, 2004). The disease has significant economic implications not only in Sub-Saharan Africa and Egypt, where it is endemic, but also internationally (Agag et al., 1992; OIE 2001). It is therefore classified as a disease that is notifiable to the OIE (2001). Economic losses are incurred because of damage to hides, reduced feed intake, pneumonia, mastitis and infertility. 
Although mortality rarely exceeds $3 \%$, it can be as high as $40 \%$ (Coetzer, 2004). The deleterious effect that the disease has in affected bulls on their ability to mate and to produce fertile sperm is often not appreciated, but has important economic implications, especially in the context of subsistence farming and in farming systems where single sires are used. A recent review article (Hunter $\&$ Wallace 2001) has identified the need for research into the epidemiology and transmission of lumpy skin disease (LSD) in South Africa because of its resurgence over the last decade of the $20^{\text {th }}$ century.

The exact method of transmission of LSDV remains unknown, but circumstantial evidence suggests that biting flies play a role as vectors (Woods, 1988). Direct or fomite-mediated transmission of LSDV between animals is inefficient (Carn \& Kitching, 1995b). The potential for transmission via semen has serious implications, particularly for the international movement of bovine semen (Hentzen, 2000). The presence of LSDV in semen can be detected by virus isolation (VI) and by polymerase chain reaction (PCR), and recently several methods of improving the diagnostic sensitivity of these methods have been published (Tuppurainen et al., 2005; Bagla et al., 2006). Although Weiss (1968) stated that LSDV is shed in semen for 22 days after the fever reaction, Irons (2005) isolated viable virus in semen 42 days after infection and identified viral DNA up to five months after infection. The risk of the presence of LSDV in semen poses a potential threat to movement of semen from countries where LSD is endemic (Hentzen, 2000). There is currently no information on the ability of semen infected with LSDV to establish clinical disease in cows inseminated with it, nor is there any data available as to the pathobiological mechanisms involved in the shedding of virus and viral particles into the ejaculate.

The objectives of this work were to determine the site of virus persistence in bulls shedding virus in semen for a period longer than 28 days, to determine if the virus is present in all fractions of the semen, to study the development of lesions in the genital tract and to compare presence of virus in such lesions with different fractions of the semen. 


\section{Materials and Methods}

\section{Animals and housing}

Six healthy Dexter bulls, which had not been vaccinated for LSD, and with no detectable neutralizing serum antibodies to LSDV were selected. All bulls were reared in semiextensive conditions on a commercial farm and were between 13 and 17 months of age. Semen containing motile spermatozoa was collected from them by electrical stimulation prior to their selection for the trial. They were housed in vector-protected stalls at the University of Pretoria's Biomedical Research Centre for the duration of the experiment. The experiment was approved by the University of Pretoria Animal Use and Care Committee (V37/04).

\section{Experimental infection, observations and sampling}

After an acclimatization period of 14 days, the bulls were artificially infected by intravenous injection of $2 \mathrm{ml}$ of a $10^{5} \mathrm{TCID}_{50} / \mathrm{ml}$ virus suspension. Virus was prepared by culture of a pathogenic field isolate of LSDV of known history (strain V248/93) on bovine dermis $(\mathrm{BD})$ cell monolayers. After harvesting the virus, infectivity was determined by titration and adjusting the infective dose to a titre of $10^{5} \mathrm{TCID}_{50} / \mathrm{ml}$. From the day of infection (day 0 ), the animals were observed daily for the development of clinical signs. Rectal temperatures were measured twice daily. A reproductive examination was performed every other day, which comprised measuring the scrotal circumference, palpation of the testes and epididymides, and an ultrasound examination of the testes and accessory sex glands using an Aloka SSD-500 ultrasound machine [Axim (Pty) Ltd, Midrand, South Africa] and $5 \mathrm{MHz}$ linear probe. A rigid $15 \mathrm{~mm}$ Perspex tube, cut longitudinally along its $40 \mathrm{~cm}$ length, was attached to the ultrasound probe and enabled evaluation of the accessory sex glands without introduction of the arm of the operator into the rectum of the animal. Blood samples were collected every other day for the duration of the trial and were subjected to VI from day 6 p.i. On day 28 , serum samples were collected and subjected to a serum neutralization test to confirm whether or not seroconversion had occurred. 
After infection of the bulls, preputial washes were performed every other day for the duration of the trial by infusing $50 \mathrm{ml}$ phosphate buffered saline (PBS) into the preputial cavity and then massaging the preputium vigorously for $1 \mathrm{~min}$ before collecting the samples. The vesicular glands were massaged per rectum prior to insertion of the probe of the electro-ejaculator and the fluid emanating from the preputial opening was collected. Semen was collected by electrical stimulation into new graduated collection tubes to which latex cones were attached. It was then centrifuged at $250 \mathrm{~g}$ for $10 \mathrm{~min}$ for separation into cell-rich and supernatant fractions. Each bull was assigned a collection cone that was used only for that bull for the duration of the trial and the collection cones were washed, scrubbed and rinsed with distilled water between uses to prevent crosscontamination of samples. Unfractionated semen samples were collected on the last day of the trial and subjected to PCR to identify the bulls that were still shedding viral DNA in their semen at that stage. A PCR was performed on the sheath washes, vesicular fluid, supernatant and cell-rich fractions of the semen from day 10 to day 26 p.i. Virus isolation was not performed on semen samples, as it has previously been determined that this method has a low sensitivity for the detection of LSDV in semen (Irons et al., 2005). The presence of blood in the semen was assessed by microscopy of semen smears stained with Diff-Quick ${ }^{\circledR}$.

Bulls that were positive by PCR on the whole semen sample collected on day 28 were slaughtered and a diagnostic postmortem was performed. The genital tracts and tissue samples from them were taken and treated accordingly for histopathological evaluation, VI and PCR. Tissue samples that showed evidence of viral-induced damage, from which virus could be isolated or in which viral DNA could be detected, were then subjected to immunoperoxidase staining and transmission electron microscopy (TEM).

\section{Polymerase chain reaction test}

The PCR was performed using a QIAmp ${ }^{\circledR}$ DNA extraction kit (QIAGEN, Southern Cross, Pretoria, South Africa) with commercially available primers for LSDV. The forward and reverse primers had the sequences $5^{\prime}$-TTTCCTGATTITTCTTACTAT- $3^{\prime}$ and $5^{\prime}$ AAATTATATACGTAAATAAC-3', respectively, rendering an expected amplicon of $192 \mathrm{bp}$ (Ireland \& Binepal, 1998). A positive control consisting of bovine semen spiked with LSDV and a negative bovine semen control as well as a water control were included in 
the PCR. Amplified products were analysed using a 100 bp DNA ladder (Whitehead Scientific (Pty) Ltd, Inqaba Biotech, Pretoria, South Africa) as a molecular marker on $1.5 \%$ agarose gels. Amplicons were visualized using an UV transilluminator at a wavelength of $590 \mathrm{~nm}$ and positive reactions were confirmed according to size.

\section{Virus isolation}

Virus isolation was performed on heparinized blood samples from day 6 p.i. and on tissue samples collected at necropsy. The cell cultures used comprised BD cells, maintained in minimum essential media containing $4 \%$ foetal calf serum and $1 \mathrm{ml}$ gentamycin $(0.1 \mathrm{mg} / \mathrm{ml})$. Flasks were incubated at $37^{\circ} \mathrm{C}$ in an atmosphere of $5 \% \mathrm{CO}_{2}$. Virus isolation from the blood samples was performed by inoculation of $0.5 \mathrm{ml}$ from each sample into the cell cultures. The cell cultures were observed daily for cytopathic effects. After 14 days, negative cultures were frozen briefly at $-70{ }^{\circ} \mathrm{C}$ and then thawed. A second passage was performed and each culture was observed for a further 14 days. Virus isolation from tissue samples was accomplished by mincing the tissue with sterile scissors and then grinding it with a pestle in a mortar containing sterile sand. Ten millilitres of PBS containing gentamycin $(0.1 \mathrm{mg} / \mathrm{ml})$, ampicillin $(0.05 \mathrm{mg} / \mathrm{ml})$ and amphotericin $B$ $(5 \mu \mathrm{g} / \mathrm{ml})$ were added to the ground-up tissue and the resulting suspension was left to stand overnight at $4^{\circ} \mathrm{C}$. The following day, suspensions were partially clarified by centrifugation at $250 \mathrm{~g}$ for 3-5 min to remove gross particles and $0.5 \mathrm{ml}$ of them was then inoculated into the BD cell cultures in $25 \mathrm{~cm}^{2}$ flasks. Negative controls were included in each batch of specimens tested. These consisted of a cell monolayer without any virus and a positive control comprising a cell monolayer inoculated with 0.2-0.5 ml LSDV (strain V248/93) suspension at a titre of $4 \log \mathrm{TCID}_{50} / \mathrm{ml}$.

\section{Histopathology and electron microscopy}

Tissue sections for histopathology were prepared using routine procedures and were stained with haematoxylin and eosin (H\&E). Immunohistochemistry, using immunoperoxidase staining, was performed on tissue sections prepared from parts of the genital tract that, on microscopic examination of $\mathrm{H} \& \mathrm{E}$ stained sections, revealed evidence of viral-induced damage. The primary antibody used for immunohistochemistry was developed in New Zealand White rabbits, following two subcutaneous inoculations of the South African Onderstepoort vaccine strain of LSDV, 21 days apart. The rabbits were 
then inoculated with gamma radiation-inactivated virus on day 31 and euthanased and exsanguinated on day 41 post-inoculation. The serum was prepared using standard procedures and stored at $-20^{\circ} \mathrm{C}$. A section from a skin nodule of a bovine with LSD (that was verified via electron microscopy) was used as the positive control section. The third series of $4 \mu \mathrm{m}$ thick sections were submitted for immunostaining with an irrelevant antibody of the same clonality as the primary antibody. In this case, a polyclonal rabies virus antiserum that had been raised in rabbits was applied to sections for staining. $A$ proven rabies-positive control section was used to ensure that the rabies antibody was functioning. The results of immunoperoxidase staining were validated against samples from the testes of bulls known to be free of LSD. Transmission electron microscopy was performed on negatively stained preparations of testis samples.

\section{Results}

\section{Clinical signs and serology}

Fever appeared on day 5 or 6 in all the animals, whereas skin lesions became apparent on day 7 in the animals that did develop them. After an incubation period of six days, two of the bulls, bull S1 and bull S2, developed severe clinical signs of LSD. They became depressed, were inappetant and remained febrile for 15 and 22 days, respectively. Generalized lymphadenopathy of the superficial lymph nodes developed in both of them from 10 days p.i. and was still present at the day of their slaughter. Multiple skin lesions consisting of raised nodules of 5-20 mm in diameter, typical of LSD, appeared mainly on the flanks, paralumbar fossae, ventrum and scrotum. These lesions became ulcerated and healed, leaving areas of scarring towards the latter part of the experiment. These two bulls also developed corneal opacities in the last two weeks of the trial and showed some respiratory distress during this period. They were treated with anti-inflammatory drugs and antimicrobials for pneumonia. Semen from these bulls was PCR positive for LSDV viral DNA on day 28 and they were subsequently slaughtered.

Bull M1 and bull M2 showed mild clinical signs of LSD consisting of fever for 4-7 days, a small number of skin lesions and mild enlargement of superficial lymph nodes, whereas infection in the remaining two bulls (I1 \& I2) was inapparent with the exception of a transient fever. 
All the bulls were serologically positive at the end of the experiment as determined by the serum neutralization test.

\section{Scrotal circumference, clinical findings in testes and epididymides}

The two bulls that showed severe clinical signs of LSD (bull S1 \& bull S2) showed pronounced changes in their scrotal circumference measurements. Their scrotal circumferences initially increased, but in bull S2 this was followed by a decline to below pre-infection values, whereas the scrotal circumference of bull S1 returned to its pre-trial value. The scrotal circumference measurements for the other four bulls showed far less variation, but it increased progressively during the trial period. Abnormalities were only detected in the scrotums, epididymides and testes of the two severely affected bulls: these included LSD nodules in the skin of the scrotums, scrotal oedema and the presence of nodules that could be palpated predominantly in the tails of the epididymides. The consistency of the testes of these two bulls decreased progressively from day 10 p.i. and was very soft by the time they were slaughtered.

\section{Ultrasonographic changes}

Ultrasonographic changes in the reproductive organs were limited to the two severely affected bulls. A transient decreased echogenicity of the parenchyma of the vesicular glands and oedema of the mucosa of the glands could be demonstrated from day 10 to day 18 p.i. In bull S1, a focal hyperechoic area of $8 \mathrm{~mm}$ in diameter could be demonstrated in the left ampulla ductus deferens from day 22 to day 28 p.i. Ultrasonographic changes of the scrotum and scrotal contents included a thickened scrotal skin, scattered hyperechoic foci in the testes (corresponding to areas of infarction seen on postmortem examination) and anechoic foci in the epididymides (subsequently found to be epididymal granulomas). These changes were first visible on day 10 p.i. and persisted for the remainder of the experiment.

\section{Postmortem examination and histopathology}

The macroscopic pathology of bulls S1 and S2 was typical for severe LSD and included multiple nodular skin lesions, corneal opacities, generalized lymphadenopathy and chronic-active interstitial pneumonia. Areas of fibrosis, necrosis and infarction could be 
visualized in the testes and epididymides.

Microscopically, in the testes of both bulls, a mild diffuse orchitis accompanied by a segmental necrosis of seminiferous tubules was visualized. The germinal compartment of the testes of bull S1 revealed the presence of normal Sertoli cells, but very few spermatogonia and spermatocytes. Some tubules in sections of the testes of this bull were totally devoid of spermatogenic cells. In contrast, sections of the testes of bull S2 showed relatively more seminiferous tubules in which spermatogonia still in contact with the basement membrane were retained. Multifocal to coalescing granulomatous epididymitis could be demonstrated in sections of the epididymides from bulls S1 and S2. In some of the more severe lesions, the entire epididymal ductule was obliterated by granulomas containing necrotic tissue.

Microscopic pathology of the accessory sex glands was restricted to the ampullae ductus deferentes in both bulls and was characterized by chronic inflammation, obstruction and secondary dilation of glandular lumina by casts of necrotic spermatids, spermatozoa and neutrophils.

\section{Immunohistochemistry}

Necrotic tissue in the testes of bulls S1 and S2 stained a pale diffuse to dark granular orange indicating the presence of LSDV antigen (Figure 1). The granulomas containing necrotic tissue in the epididymides of both bulls showed similar positive staining, some pigmented granules occurring in the cytoplasm of necrotic cells. 


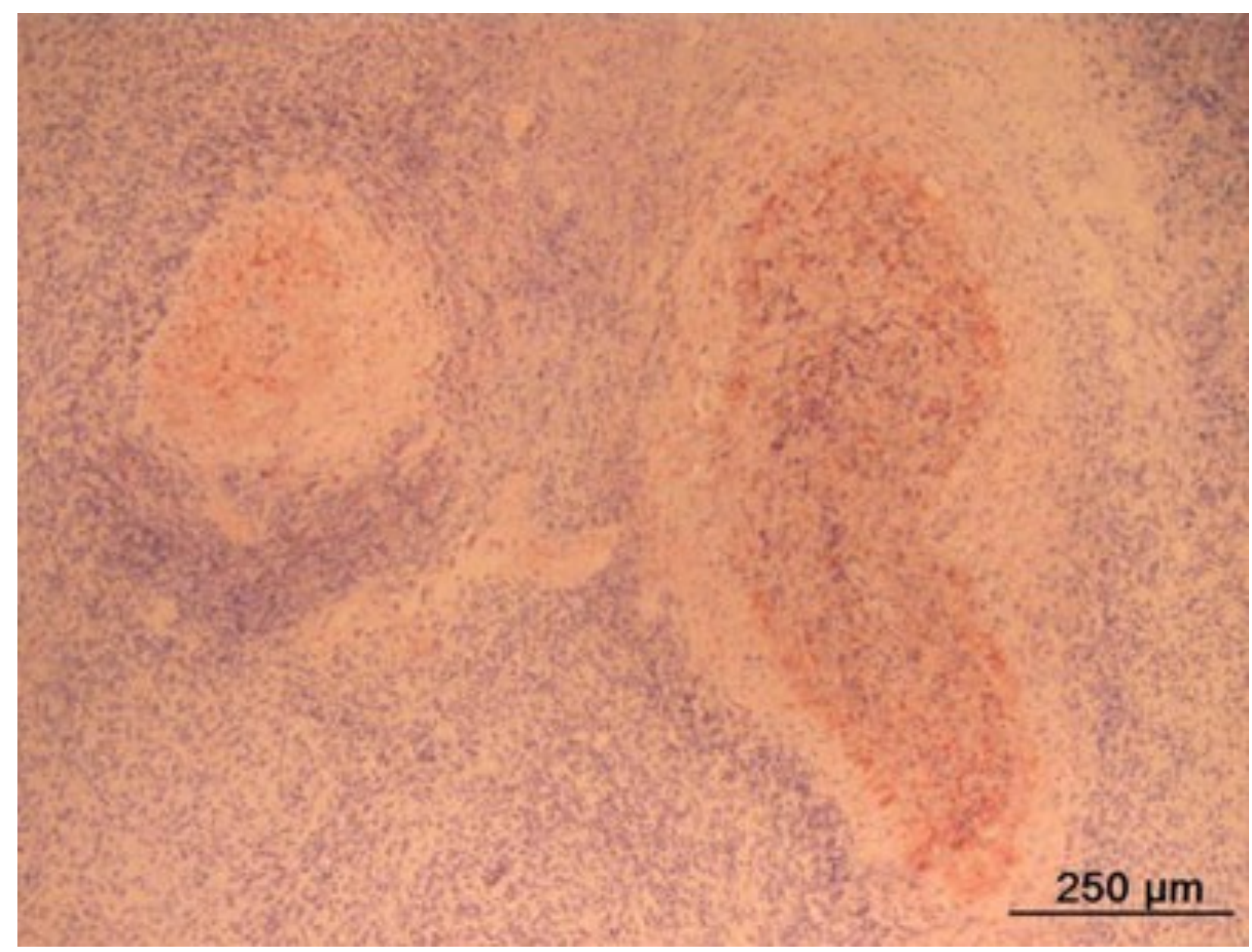

Figure 1 Photomicrograph of IMP staining in epididymal necrogranulomata

\section{Electron microscopy}

Lumpy skin disease virions could be observed in a negatively stained section of the testis from bull S1 but not bull S2 (Figure 2). Poxvirus particles could be demonstrated in waxembedded testicular sections that showed LSDV-positive staining on immunohistochemistry. 


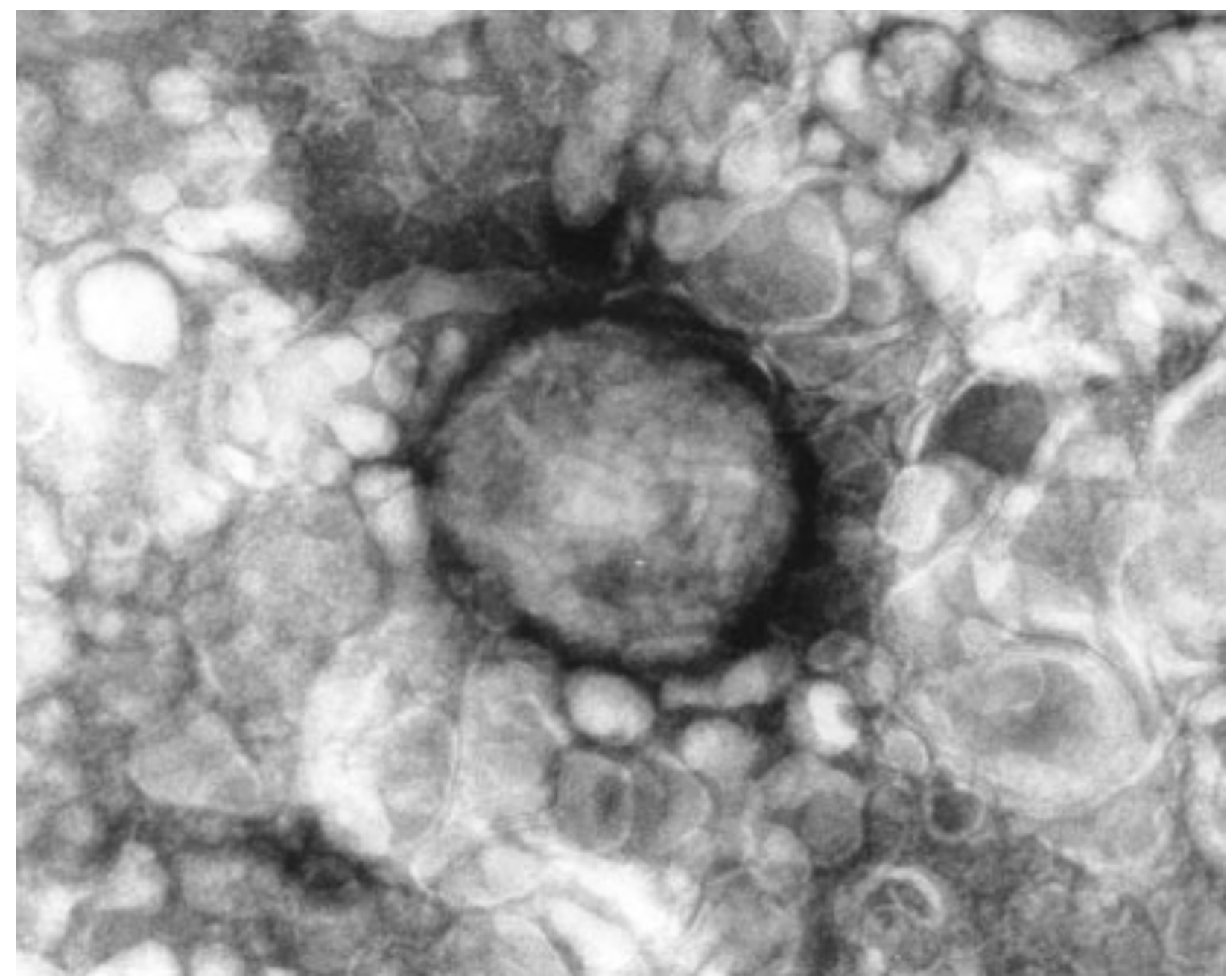

Figure 2 Electron microscopic photograph of LSDV in testis of Bull S1

\section{Virus isolation}

All bulls except bull I1 had evidence of viraemia, which was of an intermittent nature and persisted for 10-14 days in bulls S1 and S2, and four days in bulls M1 and M2, whereas virus was isolated from the blood of bull I2 only on one occasion (day 6). Virus could not be recovered from tissue samples of the ampullae, vesicular glands and prostate glands of bulls S1 and S2. Virus was only recovered from the testes of bulls S1 and S2 and the epididymis of bull S1, but not from the epididymis of bull S2.

\section{Polymerase chain reaction assay}

Viral DNA was amplified by PCR in all of the fractions of the ejaculate from all the bulls on at least one or more sampling days (data not shown). The results of viral sampling for bulls S1 and S2 are summarized in Table 1. The cell-rich fractions of bull S1 and bull 
S2 were PCR positive for all samples analysed from day 10 p.i. Viral DNA could be identified in $66.7 \%$ (6/9) of sheath wash samples, $88.9 \%$ (8/9) of vesicular fluid samples and $44.4 \%$ (4/9) of supernatant samples collected from bull S1. This is compared with $55.6 \%$ (5/9) for all these samples collected from bull S2 during the same time period. The PCR assay was consistently positive when performed on the testicular tissue from bulls $\mathrm{S} 1$ and $\mathrm{S} 2$ and epididymis of bull S1, and gave a faint positive reaction after a second PCR was performed on dilutions of extracted DNA of the epididymis of bull S2 (data not shown). Samples from the ampullae and vesicular and prostate glands of bulls S1 and S2 were negative by PCR (data not shown).

Table 1 A summary of the results on antemortem testing for the two severely affected bulls

\begin{tabular}{|c|c|c|c|c|c|c|c|c|c|c|c|c|c|}
\hline \multicolumn{2}{|c|}{ Days postinfection } & \multirow[t]{2}{*}{6} & \multirow[t]{2}{*}{8} & \multirow[t]{2}{*}{10} & \multirow[t]{2}{*}{12} & \multirow[t]{2}{*}{14} & \multirow[t]{2}{*}{16} & \multirow[t]{2}{*}{18} & \multirow[t]{2}{*}{20} & \multirow[t]{2}{*}{22} & \multirow[t]{2}{*}{24} & \multirow[t]{2}{*}{26} & \multirow[t]{2}{*}{28} \\
\hline Bull & Parameter & & & & & & & & & & & & \\
\hline \multirow[t]{6}{*}{ S1 } & Clinical signs & + & + & + & + & + & + & + & + & + & + & + & + \\
\hline & VI blood & - & + & - & + & + & + & - & + & - & - & - & - \\
\hline & PCR-SW & - & - & + & + & - & - & - & + & + & + & + & - \\
\hline & PCR-VF & - & - & + & + & + & + & - & + & + & + & + & - \\
\hline & PCR-SN & - & - & - & - & + & + & - & + & + & - & - & - \\
\hline & PCR-CR & - & - & + & + & + & + & + & + & + & + & + & $+a$ \\
\hline \multirow[t]{6}{*}{$\mathbf{S 2}$} & Clinical signs & + & + & + & + & + & + & + & + & + & + & + & + \\
\hline & VI blood & - & + & - & + & - & + & + & - & + & - & - & - \\
\hline & PCR-SW & - & - & + & + & - & + & - & + & + & + & + & - \\
\hline & PCR-VF & - & - & - & - & - & + & - & + & + & - & - & - \\
\hline & PCR-SN & - & - & - & + & + & - & - & + & + & - & + & - \\
\hline & PCR-CR & - & - & + & + & + & + & + & + & + & + & + & $+a$ \\
\hline
\end{tabular}

VI blood, virus isolation from blood; SW, sheath wash; VF, vesicular fluid; SN, semen supernatant; CR, cell rich semen fraction.

aSemen collected on day 28 p.i. was not fractionated 


\section{Discussion}

This work further confirms the phenomenon of persistent shedding of LSDV in the semen of infected bulls as described by Irons (2005). Lumpy skin disease viral DNA was found in all fractions of semen and in sheath wash samples from the bulls that were shedding virus in the semen for protracted periods of time.

The scrotal circumference of all the bulls increased shortly after the onset of fever, reached a maximum two weeks p.i. and then declined progressively until the end of the trial. The scrotal circumference of bull S1 was the same value as it was at the commencement of the experiment, whereas that of bull S2 was 15\% lower than at the start. The softness of the testes and the decreased scrotal circumference suggested severe testicular degeneration, which was confirmed at postmortem examination. Histopathological examination of the tissue specimens of the testes of bulls S1 and S2 in this experiment revealed that necrosis was the main underlying pathological change. Although not commenting specifically on testicular changes, Prozesky and Barnard (1982) concluded that vasculitis and thrombosis, leading to oedema and necrosis was central to the pathogenesis of the lesions in LSD. The initial increase in scrotal circumference can thus possibly be ascribed to an inflammatory oedema. The extent of testicular degeneration in bull S2 was more severe than in bull S1. The reason for this is unknown. A possible explanation for different animal responses to infection with LSDV is genetic resistance as determined by major histocompatibility complexes found on cell surfaces of individuals (Amills et al., 1998).

The testicular and epididymal pathology reported here is more severe than that described by Nagi (1990), as numerous seminiferous tubules were totally devoid of primary spermatogonia and extensive necrosis with obliteration of epididymal ducts could be demonstrated. Possible reasons for these differences could be the route of infection and/or the protracted illness that the bulls in the present study suffered from. The tissue specimens in the report by Nagi may have originated from animals with a generalized infection as well as from those that showed only localized skin and mucous membrane lesions. It has been shown experimentally that the first appearance and severity of such localized lesions is related to dose of virus that the animal received (Carn \& Kitching, 1995a). It is possible that the intravenous route of infection in the present study led to 
a higher generalized viral load, which had a greater effect on the spermatogonia. Spermatogenesis is determined by the amount of functional seminiferous tissue (Johnson, 1991). Severe pathology of the epididymal ducts as was present in these two bulls may also have resulted in permanent occlusion of them, which would also have resulted in a decline in fertility. It is, therefore, likely that these bulls would have suffered from reduced sperm production if they had recovered from the infection, and not been slaughtered.

In bull S1, there was a good association between lesions in the accessory sex glands, as determined by ultrasonography, and the identification of viral DNA in vesicular fluid samples by PCR. Only on one occasion ultrasonographic lesions were observed without the vesicular fluid samples simultaneously being positive by PCR. This relationship, however, was not well established in bull S2. In this bull, viral DNA was only found in vesicular fluid samples on three occasions on which ultrasonographic lesions were concurrently identified. Therefore, in animals suffering from LSD, the usefulness of ultrasonographic changes as a predictor of viral shedding in genital fluid is questionable.

The results obtained in this experiment suggest that LSDV found in the semen of affected animals is not because of contamination of the semen with blood. The semen was positive by PCR after the time when virus was no longer detectable by VI in the blood. Furthermore, semen samples were tested for the presence of blood and found to be free.

The fact that viral DNA could only be recovered from testicular and epididymal tissues in both of the bulls, which were still shedding virus 28 days p.i., combined with the fact that viral antigen could be demonstrated by immunoperoxidase staining in necrotic tissue in these organs, suggests that the testis and epididymis are the sites of persistence of the virus. While initially virus was found in both the supernatant as well as the cell-rich fraction of the semen, indicating that it was not strictly associated with the spermatozoa, it is possible that in the later stages of the persistent shedding state virus particles are associated with the sperm cell. Further research is required to investigate this aspect. It is considered that the results of the PCR performed on vesicular fluid samples should be interpreted with caution as the possibility that the samples were contaminated en transit through the preputial cavity cannot be excluded. 
The demonstration of viral antigen by immunoperoxidase staining in necrotic testicular tissue is significant. A general characteristic of members of the Poxviridae is that they are relatively resistant to unfavourable conditions, and are not dependant on the presence of live cells for their survival; LSDV has, for example, been shown to survive in skin scabs for up to 33 days (Tuppurainen et al., 2005). If virus can persist for this length of time in necrotic skin, it is likely that it survives for at least as long in necrotic testicular tissue. The voiding of such necrotic tissue into patent seminiferous tubules would explain the presence of LSDV in semen for prolonged periods and as no evidence was encountered of viral activity in other parts of the genital tract, this is deemed to be the most likely explanation for this phenomenon. Further studies are required to confirm or refute this possible phenomenon.

\section{Acknowledgements}

The authors gratefully acknowledge the assistance of Prof R C Tustin in editing the manuscript. Dr D B Wallace is given credit for valuable technical assistance and advice.

\section{Author contributions}

Dr C H Annandale planned and executed the experiment, interpreted the results and prepared the manuscript and was assisted in collection of data by Dr U I Osuagwuh. Prof E H Venter and Prof P C Irons supervised the project, secured research funds for it and edited the manuscript. Dr V P Bagla performed the laboratory analyses and edited the manuscript. 


\section{References}

Agag B I, Mousa S, Hassan H B, Saber M S, El-Deghidy N S, El-Aziz AMA. 1992. Clinical, serological and biochemical studies on lumpy skin disease. Journal of Applied Animal Research. 1, 13-23.

Amills M, Raiya V, Norimine J, Lewin H A. 1998. The major histocompatibility complex of ruminants. Revue Scientifique et Technique Office International Epizootics. 17, 108-120.

Bagla V P, Osuagwuh U I, Annandale C H, Irons P C, Venter E H. 2006. Elimination of toxicity and enhanced detection of lumpy skin disease virus on cell culture from experimentally infected bovine semen samples. Onderstepoort Journal of Veterinary Research. 73, 263268.

Carn V M, Kitching R P. 1995a. The clinical response of cattle experimentally infected with lumpy skin disease (Neethling) virus. Archives of Virology. 140, 503-513.

Carn V M, Kitching R P. 1995b. An investigation of possible routes of transmission of lumpy skin disease virus (Neethling). Epidemiology and Infection. 114, 219-226.

Coetzer J A W. 2004. Lumpy skin disease. In: Coetzer J A W, Tustin R C (Eds.), Infectious Diseases of Livestock, Vol. 2, $2^{\text {nd }}$ ed. Oxford University Press, Cape Town, South Africa. 1268-1276.

Hentzen A. 2000. Bovine Semen Risk Analysis. Report to South African Veterinary Semen and Embryo Group of the South African Veterinary Association, Pretoria, South Africa.

Hunter P, Wallace D. 2001. Lumpy skin disease in southern Africa: a review of the disease and aspects of control. Journal of the South African Veterinary Association. 72, 68-71.

Ireland D C, Binepal Y S. 1998. Improved detection of capripoxvirus in biopsy samples by PCR. Journal of Virological Methods. 74, 1-7.

Irons P C, Tuppurainen E S M, Venter E H. 2005. Excretion of lumpy skin disease virus in bull semen. Theriogenology. 63, 1290-1297.

Johnson L. 1991. Spermatogenesis. In: Cupps P T (Ed.), Reproduction in Domestic Animals, $4^{\text {th }}$ ed. Academic Press Inc, San Diego. 173-219.

Nagi A A. 1990. Lumpy skin disease: cutaneous and testicular lesions. Assiut Veterinary Medical Journal. 23, 90-99.

OIE. 2001. Lumpy skin disease. Bulletin - Office International des Epizooties. 113, 703-901.

Prozesky L, Barnard B J H. 1982. A study of the pathology of lumpy skin disease in cattle. Onderstepoort Journal of Veterinary Research. 49, 167-175.

Tuppurainen E S M, Venter E H, Coetzer ] A W. 2005. The detection of lumpy skin disease virus in samples of experimentally infected cattle using different diagnostic techniques. Onderstepoort Journal of Veterinary Research. 72, 153-164.

Weiss K E. 1968. Lumpy skin disease virus. Virology Monographs. Springer, Vienna. 111-131.

Woods J A. 1988. Lumpy skin disease virus - a review. Tropical Animal Health and Production. 20, 11-17. 


$$
3
$$




\section{Chapter 3}

\section{Seminal transmission of lumpy skin disease virus in heifers}

\section{H Annandale ${ }^{1}$, D E Holm ${ }^{1}$, K Ebersohn² and E H Venter ${ }^{2}$}

${ }^{1}$ Department of Production Animal Studies, University of Pretoria, Onderstepoort, South Africa

${ }^{2}$ Department of Veterinary Tropical Diseases, Faculty of Veterinary Science, University of Pretoria, Onderstepoort, South Africa 


\section{Summary}

It is known that lumpy skin disease virus (LSDV) can be shed in bull semen following infection and also that artificial insemination (AI) poses a biosecurity risk. However, it is not known whether the use of LSDV infected semen in AI poses a biosecurity risk. The aim of this study was to investigate whether LSDV, transmitted through semen, can infect cows and their embryos. Two controlled trials were performed simultaneously. Eleven young beef heifers, naïve to LSDV, were synchronized using an OvSynch protocol and inseminated on day 0 with fresh semen spiked with a field strain of LSDV on day 0 . Six of the heifers were superovulated on day 1 using pregnant mare serum gonadotropin, and embryos were flushed from these heifers on day 6 . Blood and serum samples were collected from day 4 until day 27 to determine the presence of LSDV by PCR and virus isolation, and the presence of antibodies against LSDV by SNT. The first clinical signs of LSD were noticed on day 10, followed by severe generalized LSD in three heifers and mild LSD in two more heifers. Two heifers were humanely euthanized due to severe unresponsive stranguria. LSDV was detected by PCR, virus isolation or electron microscopy in blood, embryos and organs of experimentally infected animals; and eight heifers had seroconverted by day 27. Two control animals were not affected. This is the first report of experimental seminal transmission of LSDV in cattle. 


\section{Introduction}

Lumpy skin disease virus (LSDV), a member of the genus Capripoxvirus within the family Poxviridae, causes an imperceptible to acute disease in cattle, characterized by firm, circumscribed skin nodules, necrotic plaques in the mouth and nares, fever and generalized lymphadenopathy (Coetzer, 2004). Due to pneumonia, infertility, reduced feed intake and a harmful effect on the quality of hides, economic losses associated with the disease can be substantial (Woods, 1988). Although endemic to Sub-Saharan Africa, lumpy skin disease (LSD) has the potential to spread to other parts of Africa, the Middle East and Europe (Tuppurainen \& Oura, 2012).

A number of possible routes of transmission for LSDV have been investigated and identified. These include arthropods, biting insects and mosquitoes (Kitching \& Taylor, 1985; Kitching \& Mellor, 1986; Carn \& Kitching, 1995; Chihota et al., 2001, 2003). The role of ticks in transmission has been suspected (Aiel, 2009) with observations of the presence of ticks made on affected animals in some outbreaks (especially Amblyomma ticks) (Ali \& Obeid, 1977). A recent study indicated that transstadial and transovarial transmission of LSDV by Rhipicephalus (Boophilus) decoloratus ticks and mechanical or intrastadial transmission by Rhipicephalus appendiculatus and Amblyomma hebraeum ticks were possible (Tuppurainen et al., 2010). The mechanical transmission of LSDV by $R$. appendiculatus male ticks has also now been confirmed (publication submitted).

Transmission through artificial insemination (AI) has been observed in different animal species e.g., for equine arteritis virus (Guthrie et al., 2003), porcine reproductive and respiratory syndrome virus (Christopher-Hennings et al., 1995), classical swine fever virus (Smit et al., 1999) and feline immunodeficiency virus (Jordan et al., 1996).

In bovines, foot-and-mouth disease virus and bovine herpes virus 1 can be transmitted to susceptible heifers by insemination with infected semen (Afshar \& Eaglesome, 1990). Intra-uterine inoculation with ephemeral fever virus did not result in seroconversion or production of the disease (Kahrs et al., 1980), and bovine leukaemia virus (BLV) could not be transmitted via leucocyte-free semen from BLV-infected bulls (Kaja \& Olson, 1982). 
Recent research has indicated the presence of LSDV in semen and the possible risk of transmission of the disease via this route. In a study by Irons (2005), virus particles were detected in semen of experimentally infected animals for up to five months, when clinical signs were no longer evident. Following an initial drastic deterioration in semen quality during the acute phase of the infection, the quality of the semen recovered before the end of the period of virus excretion (Irons et al., 2005).

It was also shown that LSDV is not limited to specific fractions of the ejaculate and the testes and epididymides are most profoundly affected (Annandale et al., 2010). The virus was not thought to be sperm or blood associated, and it was concluded that the ejaculate was likely to have been contaminated with virus that was being shed during emission from necrotic lesions in the genital tract (Annandale et al., 2010). The risk posed to in vitro fertilization (IVF) procedures was also demonstrated. It was established that the virus was sperm-associated in $9 \%$ of spermatozoa, and that the early blastocyst contained viral DNA (Irons, 2008). The contradictory finding of sperm association of virus in these two studies needs further investigation to establish the significance thereof.

There is a high demand by other countries for breeding material such as embryos and semen from South African cattle (Kahrs et al., 1980; De la Rey, 2003). In particular, AI is an extremely effective means of disseminating genetic material, and at present semen exports exceed embryo exports. Lumpy skin disease virus is one of the viruses identified in semen risk analysis as a potential hazard in the international movement of bovine semen (Hentzen, 2000). There is currently no published information on the ability of LSDV infected semen to establish clinical disease in cows naturally or artificially by insemination i.e., trans-uterine infection. No further data are available on the effect of the use of infected semen for in vivo fertilization of oocytes, or on the potential for the spread of the disease to recipients of embryos produced in this way.

The objectives of the current study were therefore to assess the possibility of transmission of LSDV through semen and subsequent LSDV infection in cows and embryos. 


\section{Materials and Methods}

\section{Animals}

Thirteen healthy, thin-skinned European breed heifers from a diverse genetic pool were sourced from herds where LSD had not been seen for three years, and where no vaccination was practiced. Only animals that tested negative for antibodies to LSDV by using the serum neutralization test (SNT) were selected and kept at the insect-free stables of the Biological Research Centre of the University of Pretoria (UPBRC), Faculty of Veterinary Science.

The experiment was divided into two trials - each with one control animal. The two trials ran simultaneously and were only denoted as two trials for simplification of the experimental design.

Trial I investigated the possible effect of LSDV on embryo parameters in vivo. Heifers in this trial were called 'Embryo heifers'. Trial II investigated the response of heifers to insemination with semen spiked with an infective dose of LSDV. Heifers in this trial were called 'AI heifers'.

The heifers were divided into groups of six (Embryo Group) and seven animals (AI Group) each. Oestrus was synchronized in all heifers using the OvSynch protocol. Briefly, this involved intramuscular injections of $100 \mu \mathrm{g}$ buserelin (Fertagyl ${ }^{\circledR}$ ) on day -10 , a luteolytic dose of prostaglandin F2 $\alpha$ (Lutalyse ${ }^{\circledR}$ ) on day -3 , another injection of buserelin on day -1 and insemination 17-24 hrs after the second buserelin injection. The day of insemination was denoted day 0 . Embryo heifers were superovulated using a single injection of pregnant mare serum gonadotropin (PMSG) on the day of the second buserelin injection (Pursley \& Bello, 2007).

\section{LSDV preparation}

A South African field isolate (V248/93) was used to spike semen as challenge material for experimental animals. The infectivity of the field isolate had previously been established (Tuppurainen et al., 2005). Bovine dermis cells prepared from a foetal calf's ear were cultured in $75 \mathrm{~cm}^{2}$ tissue culture flasks in Minimum Essential Medium (MEM) 
supplemented with L-glutamine ( $1 \mathrm{ml} / \mathrm{l}), 0,2 \%$ sodium bicarbonate (Highveld Biological, Lyndhurst, Johannesburg, Gauteng), $5 \%$ foetal calf serum (Adcock Ingram, Midrand, Gauteng) and $1 \mathrm{ml} / /$ gentamycin (50 mg/ml Genta 50 Phenix). When $70 \%-80 \%$ of the cell monolayer was confluent, a volume of $0.5 \mathrm{ml}$ of virus isolate was inoculated into a $75 \mathrm{~cm}^{2}$ flask. Virus was harvested when $90 \%-100 \%$ of the cell monolayer was infected and showed typical cytopathic changes. Culture flasks were frozen briefly at $-70^{\circ} \mathrm{C}$, then thawed and the flasks shaken gently to release the cell-associated virus. The cell cultures were centrifuged at $448 \mathrm{~g}$ for $3 \mathrm{~min}$. The supernatant was removed and aliquoted in volumes of 1.8 and $3.5 \mathrm{ml}$ in cryo tubes (Nunc, Amersham, Johannesburg, South Africa) and stored as reference stock virus at $-70^{\circ} \mathrm{C}$ until used. The reference stock virus was titrated on bovine dermis cells using 96-well microtitre plates, including the cell control. Cells were observed daily for $\mathrm{CPE}$, and the TCID ${ }_{50}$ of the virus was calculated using the method of Reed and Miuench (1938).

\section{Experimental challenge with spiked semen}

On day 0,11 animals were inseminated with $1 \mathrm{ml}$ of fresh semen spiked with $1 \mathrm{ml}$ of LSDV virus suspension. The titre of the virus used was $5.5 \log \operatorname{TCID}_{50} / \mathrm{ml}$. A control in each group consisted of an animal inseminated with an equivalent dose of unspiked semen.

\section{Sample Collection and Observation}

All animals were observed daily for habitus and development of clinical signs. Rectal temperature was taken twice daily. Blood samples were collected in EDTA and heparin from all animals on 2, 6, 9, 12, 16, 20, 23 and 27 days post-infection (dpi), and subjected to PCR and virus isolation. Serum samples were collected on 9, 12, 16, 20, 23 and 27 dpi and subjected to SNT.

On day 6, the five treatment heifers and one control heifer (EM heifers) received epidural anaesthesia, an embryo flushing catheter was passed into the uterine horns alternately and the embryos were flushed from the horns with embryo flushing media. Before use, the flushing media was confirmed free of bovine viral diarrhoea virus (BVDV) using a RTnPCR (Qiagen Cador BVDV Type 1/2 real-time RT-PCR Kit, Qiagen, Hilden, Germany). Embryos were washed as described in the Manual of the International Embryo Transfer 
Society (IETS) (Stringfellow \& Seidel, 1998) and tested for the presence of LSDV by PCR. The samples that were positive by PCR were subjected to virus isolation. The Embryo heifers stayed in the experiment until day 27 , after which time they were removed.

On day 28 , ultrasound pregnancy diagnosis per rectum was performed on the AI heifers. Pregnant heifers were retained until day 42 , but non-pregnant heifers were removed from the trial.

\section{Laboratory testing}

To detect the presence of LSDV DNA in EDTA blood samples, embryos, flushing media and organs, PCR was performed using the primers of Ireland and Binepal (1998). Virus isolation was carried out on bovine dermis cell monolayers according to the method described by Tuppurainen (2005). To determine seroconversion, an SNT was performed using a 96-well plate format according to the standard protocol of the Virology Section, Department of Veterinary Tropical Diseases, Faculty of Veterinary Science, University of Pretoria (OIE, 2010). Grading of embryos flushed from Embryo heifers was conducted according to the guidelines of the Manual of the IETS (Stringfellow \& Seidel, 1998). Electron microscopy was performed on skin lesions by the EM-Section, Faculty of Veterinary Science, University of Pretoria. Immunoperoxidase staining of the uterine tissues were carried out by the section of Pathology, Faculty of Veterinary Science, University of Pretoria.

\section{Results}

\section{AI heifers}

In the AI group, three of the seven animals tested positive for viral DNA in blood between 10 and $17 \mathrm{dpi}$, and five animals had seroconverted by the end of the trial. The three clinically affected heifers in the AI group showed severe clinical signs, especially affecting the reproductive tract. Due to extreme, non-responsive stranguria and extensive necrosis of their caudal reproductive tracts, two of these heifers were humanely destroyed and postmortem examinations were performed. 


\section{Embryo heifers}

Embryos were harvested from two infected heifers, and these embryos were found positive for LSDV DNA by PCR. Virus could also be isolated from both embryos using cell cultures. Stepwise washing as per IETS guidelines rendered the embryos free of LSDV DNA (Stringfellow \& Seidel, 1998). One heifer tested PCR positive and VI positive on day 16 and day 23 respectively, while the other heifer remained negative for the duration of the trial (Table 1). Neither PCR nor virus isolation could identify LSDV infection in the flushing media recovered from the other heifers. Three of the five experimental heifers in the EM group had seroconverted by the end of the trial (Table 1). 
Table 1 Clinical and laboratory findings and the amount of animals in which a positive result was found

\begin{tabular}{|c|c|c|c|c|c|c|c|c|c|c|c|}
\hline \multicolumn{2}{|c|}{ Days post-infection } & \multirow[t]{2}{*}{2} & \multirow[t]{2}{*}{6} & \multirow[t]{2}{*}{9} & \multirow[t]{2}{*}{10} & \multirow[t]{2}{*}{11} & \multirow[t]{2}{*}{12} & \multirow[t]{2}{*}{16} & \multirow[t]{2}{*}{20} & \multirow[t]{2}{*}{23} & \multirow[t]{2}{*}{27} \\
\hline Group & Parameter & & & & & & & & & & \\
\hline \multirow{5}{*}{$\begin{array}{l}\text { AI } \\
(n=6)\end{array}$} & Clinical signs & & & & 1 & 3 & 3 & 3 & 3 & 2 & 1 \\
\hline & VI & & & 1 & & & & & & & \\
\hline & SNT & & & & & & & & 5 & 4 & 4 \\
\hline & PCR & & & 1 & & & & 2 & & & \\
\hline & Death & & & & & & & & & 1 & 1 \\
\hline \multirow{7}{*}{$\begin{array}{l}\text { EM } \\
(n=5)\end{array}$} & Clinical signs & & & & & 2 & 2 & 3 & 3 & 3 & 3 \\
\hline & VI blood & & & & & & & & & 1 & \\
\hline & PCR & & & & & & & 1 & & & \\
\hline & SNT & & & 1 & & & & 1 & 2 & 2 & 3 \\
\hline & VI embryo & & 2 & & & & & & & & \\
\hline & PCR embryo & & 2 & & & & & & & & \\
\hline & Death & & & & & & & & & & \\
\hline
\end{tabular}

AI, artificial insemination; VI, virus isolation; SNT, serum neutralization test; PCR, polymerase chain reaction; EM, embryo

In all affected animals, five in total, the first clinical signs of LSD infection were visible 10 days after experimental infection in the form of a severely swollen vulva. Fever reactions appeared from $11 \mathrm{dpi}$ and were accompanied by characteristic skin nodules. Generalized lymph-adenopathy was observed from $13 \mathrm{dpi}$. Severe generalized LSD could be seen in three of the heifers, mild LSD in another two heifers, while the other heifers showed no obvious clinical signs. None of the heifers was found to be pregnant when ultrasonographic examination was performed 28 days after AI. None of the control animals tested positive by PCR or had seroconverted by the end of the trial (Table 1).

\section{Necropsy findings}

Sub-acute to chronic-active, severe diffuse haemorrhagic, deeply necrotic to sloughing vulvovaginitis and metritis were observed macroscopically during necropsy. The ovaries appeared normal with follicles in different developmental stages visible. Microscopically, severe, multifocal thromboses with concurrent infarction, ischaemia and tissue devitalization characterized the uterus. Severe vasculitis combined with a lymphoplasmacytic cell infiltrate was present. Immunoperoxidase staining of the uterine 
tissues revealed positive, red granular cytoplasmic staining with an apparent predilection for macrophages. LSD viral DNA and virus could be demonstrated by PCR and VI in the reproductive organs (excluding ovaries) of both heifers. Transmission electron microscopy demonstrated LSD virus in skin samples.

\section{Discussion}

The risk of transmitting LSDV via semen is not only a major concern mainly for the export industry in South Africa, but also by determining the significance of the presence of the virus in semen, light will be shed on the epidemiology of the disease. The persistent shedding of LSDV in the semen of infected bulls was described by both Irons (2005) and Tuppurainen (2005), while the presence of viral DNA was demonstrated in all fractions of semen and in sheath wash samples from bulls that were shedding virus in semen for protracted periods of time (Annandale et al., 2010). This trial is the first experimental demonstration of seminal transmission of LSDV in heifers, thereby confirming the biosecurity risk posed by semen infected with LSDV.

Although many viruses are known to be shed in the semen of bulls (Afshar \& Eaglesome, 1990), the true significance of the presence of virus in semen seems unclear. Burgess (1973) inseminated heifers with bovine ephemeral virus and failed to produce clinical disease, but did manage to show the development of antibodies two weeks after insemination. Similarly, Kupferschmied (1986) demonstrated humoral immunity subsequent to AI with semen spiked with bovine herpes virus 1 but was only able to induce very slight clinical signs of infectious bovine rhinotracheitis (IBR). Seminal transmission of bovine viral diarrhea virus (BVDV) was demonstrated, as well as foetal infection via placental circulation (Meyling \& Jensen, 1988). Reports of persistently infected calves following insemination with BVDV-infected semen (Niskanen et al., 2002) support the epidemiological role of BVDV in the spread of the disease and justifies the control measures that are in place.

In the current trial, seroconversion could be demonstrated in eight of the 11 heifers inseminated with semen spiked with LSDV. Babiuk (2008) established that the shedding of LSDV is low in bodily secretions (semen was not investigated specifically), and that the 
highest concentration of viral particles could be found in skin lesions. We postulate therefore that it is unlikely that similar infection rates would be achieved in herds where natural mating takes place or in herds where $\mathrm{AI}$ is practiced, considering the expected lower infective dose. The natural infective dose in semen still remains to be established. Serologically, the detection of an SNT positive sample on 9 dpi is unusual. Irons (2005) detected the first positive SNT sample on $12 \mathrm{dpi}$. Possible explanations for the difference in results of the two trials could be the higher viral load used in the current trial and the intra-uterine route of infection, allowing different exposures to the immune system than the intravenous or intradermal route of infection.

The low pregnancy rates in this trail are noteworthy. While the exact reason for this was not investigated, the effect of viraemia or a direct virus effect cannot be excluded.

Necropsy results are similar to what has been previously reported in the literature (Prozesky \& Barnard, 1982; Nagi, 1990; Annandale et al., 2010). In the current trial, LSD skin lesions seemed less severe. However, lesions on mucous membranes, especially of the conjunctiva, nose, mouth and reproductive tract seemed more pronounced than what can normally be seen in the field (Coetzer, 2004). The difference in severity of clinical disease between the AI group and Embryo group suggests that embryo flushing on day 6 had a protective effect on the reproductive tracts of the heifers in the ET group. Of the two animals that were necropsied, one had outspoken necrosis in the entire reproductive tract while the other one had only vaginal and vestibular necrosis. This finding might indicate that the clinical signs associated with LSDV infection via natural mating may differ from that of AI, as the cervix serves as a natural barrier during mating. This finding warrants further investigation. It has to be noted though that the small number of experimental animals in this trial precludes statistical analysis and definitive conclusions.

The current study confirms transmission of LSDV to heifers and embryos through AI. The high titre of virus used to spike semen in the current trial precludes conclusions on the quantification of the biosecurity risks associated with the presence of LSDV in bovine semen under field conditions. Further studies are indicated to investigate the biosecurity risk under field conditions. The effect of the route of infection on the clinical course of clinical LSD similarly needs further investigation. 


\section{Acknowledgements}

This project was funded by the NRF. Project number FA 200704250000. 


\section{References}

Afshar A, Eaglesome M D. 1990. Viruses associated with bovine semen. The Veterinary Bulletin. 60, 93-109.

Aiel K. 2009. Lumpy skin disease. Bovine and Ovine Magazine. 67, 22-24.

Ali B H, Obeid H M. 1977. Investigation of the first outbreaks of lumpy skin disease in the Sudan. British Veterinary Journal. 133, 184-189.

Annandale C H, Irons P C, Bagla V P, Osuagwuh U I, Venter E H. 2010. Sites of persistence of lumpy skin disease virus in the genital tract of experimentally infected bulls. Reproduction in Domestic Animals. 45, 250-255.

Babiuk S, Bowden T R, Parkyn G, Dalman B, Manning L, Neufeld J, Embury-Hyatt C, Copps J, Boyle D B. 2008. Quantification of lumpy skin disease virus following experimental infection in cattle. Transboundary and Emerging Diseases. 55, 299-307.

Burgess G W. 1973. Attempts to infect cattle with bovine ephemeral fever by inoculation of virus into the cervix. Australian Veterinary Journal. 49, 341-343.

Carn V M, Kitching R P. 1995. An investigation of possible routes of transmission of lumpy skin disease virus (Neethling). Epidemiology and Infection. 114, 219-226.

Chihota C M, Rennie L F, Kitching R P, Mellor P S. 2001. Mechanical transmission of lumpy skin disease virus by Aedes aegypti (Diptera: Culicidae). Epidemiology and Infection. 126, 317-321.

Chihota C M, Rennie L F, Kitching R P, Mellor P S. 2003. Attempted mechanical transmission of lumpy skin disease virus by biting insects. Medical and Veterinary Entomology. 17, 294300.

Christopher-Hennings J, Nelson E A, Hines R J, Nelson J K, Swenson S L, Zimmerman J J, Chase C L L, Yaeger M J, Benfield D A. 1995. Persistence of porcine reproductive and respiratory syndrome virus in serum and semen of adult boars. Journal of Veterinary Diagnostic Investigation. 7, 456-464.

Coetzer J A W. 2004. Lumpy skin disease. In: Coetzer J A W, Tustin R C (Eds.), Infectious Diseases of Livestock. Vol. 2, $2^{\text {nd }}$ ed. Oxford University Press, Cape Town, South Africa. 1268-1276.

Guthrie A J, Howell P G, Hedges J F, Bosman A M, Balasuriya U B R, McCollum W H, Timoney P J, Mac-Lachlan N J. 2003. Lateral transmission of equine arteritis virus among Lipizzaner stallions in South Africa. Equine Veterinary Journal. 35, 596-600.

Hentzen A. 2000. Bovine Semen Risk Analysis: Report to South African Veterinary Semen and Embryo Group of the South African Veterinary Association.

Ireland D C, Binepal Y S. 1998. Improved detection of capripoxvirus in biopsy samples by PCR. Journal Virology Methods. 74, 1-7.

Irons P C. 2008. The Bull as a Source of Pathogens: A Southern African Perspective. Utrecht University, the Netherlands. 
Irons P C, Tuppurainen E S M, Venter E H. 2005. Excretion of lumpy skin disease virus in bull semen. Theriogenology. 63, 1290-1297.

Jordan H L, Howard J, Sellon R K, Wildt D E, Tompkins W A, Kennedy-Stoskopf S. 1996. Transmission of feline immunodeficiency virus in domestic cats via artificial insemination. Journal of Virology. 70, 8224-8228.

Kahrs R F, Gibbs E P J, Larsen R E. 1980. The search for viruses in bovine semen, a review. Theriogenology. 14, 151-165.

Kaja R W, Olson C. 1982. Non-infectivity of semen from bulls infected with bovine leukosis virus. Theriogenology. 18, 107-112.

Kitching R P, Mellor P S. 1986. Insect transmission of capripoxvirus. Research in Veterinary Science. 40, 255-258.

Kitching R P, Taylor W P. 1985. Transmission of capripoxviruses. Research in Veterinary Science. 39, 196-199.

Kupferschmied H U, Kihm U, Bachmann P, Müller K H, Ackermann M. 1986. Transmission of IBR/IPV virus in bovine semen: a case report. Theriogenology. 25, 439-443.

Meyling A, Jensen A M. 1988. Transmission of bovine virus diarrhoea virus (BVDV) by artificial insemination (AI) with semen from a persistently-infected bull. Veterinary Microbiology. 17, 97-105.

Nagi A A. 1990. Lumpy skin disease: cutaneous and testicular lesions. Assiut Veterinary Medical Journal. 23, 90-99.

Niskanen R, Alenius S, Bel'ak K, Baule C, Bel'ak S, Voges H, Gustafsson H. 2002: Insemination of susceptible heifers with semen from a non-viraemic bull with persistent bovine virus diarrhoea virus infection localized in the testes. Reproduction in Domestic Animals. 37, 171-175.

OIE. 2010. Manual of Diagnostic Tests and Vaccines for Terrestrial Animals. Chapter 2.4.14, Lumpy Skin Disease. Office International des Epizooties, Paris.

Prozesky L, Barnard B J H. 1982. A study of the pathology of lumpy skin disease in cattle. Onderstepoort Journal of Veterinary Research. 49, 167-175.

Pursley J R, Bello N M. 2007. Ovulation synchronisation strategies. In: Youngquist R S, Threlfall W R (Eds.), Current Therapy in Large Animal Theriogenology, $2^{\text {nd }}$ ed. Saunders Elsevier, St. Louis, MO. 287-293.

Reed L J, Miuench H. 1938. A simple method of estimating fifty per cent endpoints. American Journal of Hygiene. 27, 493-497.

De la Rey R. 2003. Welcoming address. South African Veterinary Semen and Embryo Group of the South African Veterinary Association.

Smit A J D, Bouma A, Terpstra C, Oirschot J T V. 1999. Transmission of classical swine fever virus by artificial insemination. Veterinary Microbiology. 67, 239-249.

Stringfellow D A, Seidel S M. 1998. Manual of the International Embryo Transfer Society, $3^{\text {rd }}$ ed., IETS, Savoy, IL. 
Tuppurainen E S M, Oura C A L. 2012. Review: lumpy skin disease: an emerging threat to Europe, the Middle East and Asia. Transboundary and Emerging Diseases. 59, 40-48.

Tuppurainen E S M, Venter E H, Coetzer J A W. 2005. The detection of lumpy skin disease virus in samples of experimentally infected cattle using different diagnostic techniques. Onderstepoort Journal of Veterinary Research. 72, 153-164.

Tuppurainen E S M, Stoltsz W H, Troskie M, Wallace D B, Oura C, Mellor P S, Coetzer J A W, Venter $E$ H. 2010. A potential role for hard (ixodid) tick vectors in the transmission of lumpy skin disease virus in cattle. Transboundary and Emerging Diseases. 58, 93-104.

Woods J A. 1988. Lumpy skin disease virus - a review. Tropical Animal Health Production. 20, 11-17. 
4 


\section{Chapter 4}

\section{Effect of using frozen-thawed bovine semen contaminated with lumpy skin disease virus on in vitro embryo production}

C. Henry Annandale ${ }^{1}$, Mario P. Smuts ${ }^{1}$, Karen Ebersohnn ${ }^{2}$, Lizette du Plessis ${ }^{3}$, Peter N. Thompson ${ }^{1}$, Estelle H. Venter ${ }^{2,4}$, Tom A. E. Stout ${ }^{1,5}$

${ }^{1}$ Department of Production Animal Studies, Faculty of Veterinary Science, University of Pretoria, Onderstepoort, South Africa

2Department of Veterinary Tropical Diseases, Faculty of Veterinary Science, University of Pretoria, Onderstepoort, South Africa

${ }^{3}$ Department of Anatomy and Physiology, Faculty of Veterinary Science, University of Pretoria, Onderstepoort, South Africa

${ }^{4}$ School of Public Health, Medical and Veterinary Sciences, Discipline: Veterinary Science, James Cook University, Townsville, QLD, Australia

${ }^{5}$ Department of Equine Sciences, Faculty of Veterinary Medicine, Utrecht University, Utrecht, The Netherlands

\section{Correspondence}

Dr Cornelius Henry Annandale, Department of Production Animal Studies, Faculty of Veterinary Science, University of Pretoria, Onderstepoort, South Africa.

Email: henry.annandale@up.ac.za

WILEY DOI: 10.1111/tbed.13179. Transboundary and Emerging Diseases. 2019. 1-9. 


\section{Summary}

Lumpy skin disease (LSD) is an important transboundary animal disease of cattle with significant economic impact because of the implications for international trade in live animals and animal products. LSD is caused by a Capripoxvirus, LSD virus (LSDV), and results in extensive hide and udder damage, fever and pneumonia. LSDV can be shed in semen of infected bulls for prolonged periods and transmitted venereally to cows at high doses. This study examined the effects of LSDV in frozen-thawed semen on in vitro embryo production parameters, including viral status of media and resulting embryos. Bovine oocytes were harvested from abattoir-collected ovaries and split into three experimental groups. After maturation, the oocytes were fertilized in vitro with frozenthawed semen spiked with a high (HD) or a lower (LD) dose of LSDV, or with LSDV-free semen (control). Following day 7 and day 8 blastocyst evaluation, PCR and virus isolation were performed on all embryonic structures. After completing sufficient replicates to reach 1,000 inseminated oocytes, further in vitro fertilization (IVF) runs were performed to provide material for electron microscopy (EM) and embryo washing procedures. Overall, in vitro embryo yield was significantly reduced by the presence of LSDV in frozenthawed semen, irrespective of viral dose. When semen with a lower viral dose was used, significantly lower oocyte cleavage rates were observed. LSDV could be detected in fertilization media and all embryo structures, when higher doses of LSDV were present in the frozen-thawed semen used for IVF. Electron microscopy demonstrated LSDV virions inside blastocysts. Following the International Embryo Transfer Society washing procedure resulted in embryos free of viral DNA; however, this may be attributable to a sampling dilution effect and should be interpreted with caution. Further research is required to better quantify the risk of LSDV transmission via assisted reproductive procedures.

\section{Keywords}

bovine embryo, culture media, in vitro fertilization, lumpy skin disease virus 


\section{Introduction}

Lumpy skin disease (LSD) is considered a transboundary animal disease of importance in cattle with significant economic impact due to the implications for food security, production losses, and restrictions in trade placed on countries where the disease is present (Tuppurainen \& Oura, 2012). The causative agent of LSD, LSD virus (LSDV), is a member of the genus Capripoxvirus and exerts its major pathogenic effects through granulomatous reactions in the dermis and hypodermis, following an initial vasculitis and lymphangitis (Prozesky \& Barnard, 1982). Lumpy skin disease is associated with fever, lachrymation, lymphadenopathy, nodules on the skin and internal organs, weight loss, inappetence and, in rare cases, pneumonia and death (Coetzer, 2004). While initially restricted to Africa, LSD has recently spread further afield and is now considered a direct threat to Europe and Great Britain (Beard, 2016; Tuppurainen \& Oura, 2014). The precise origin of LSD outbreaks is rarely proven, but illegal movement of farm animals without proper health checks and the collapse of veterinary services due to political uncertainty have been implicated (Tuppurainen et al., 2017).

In vitro production (IVP) of bovine embryos has grown appreciably over the last two decades, but international trade in IVP embryos is relatively uncommon, reflecting, in part, the concern of veterinary regulatory authorities with regard to the potential risks of transmitting diseases via IVP embryos (Da Silva Cardoso Pinto et al., 2017). The most important viruses that have been associated with a risk of transmission via bovine IVP embryos are bovine viral diarrhea virus (BVDV), bovine herpesvirus-1 (BHV-1), enzootic bovine leucosis virus and bluetongue virus (BTV) (Wrathall, Simmons \& Van Soom, 2006). Recent reports of LSDV entering the semen of infected bulls (Irons, Tuppurainen \& Venter, 2005), transmission of the virus to heifers via contaminated semen, infection of in vivo-derived embryos (Annandale, Holm, Ebersohn \& Venter, 2014) and intrauterine transmission to a premature calf (Rouby \& Aboulsoud, 2016), have all raised concerns that LSDV might also pose a risk in IVP embryo production systems.

Cattle that become infected with LSDV, either experimentally or naturally, display variable clinical signs; ranging from almost none to severe generalized LSD. It is now known that LSDV can be shed in the semen of experimentally infected bulls for up to 159 days (Irons et al., 2005), although the nature of this shedding is not well characterized. Indeed, 
semen shedding of virus mirrors the general clinical syndrome i.e. that the amount, quantity and duration of shedding is variable and difficult to predict (Annandale, Irons, Bagla, Osuagwuh \& Venter, 2010; Babiuk et al., 2008).

In countries free of LSD, import restrictions apply to livestock, carcasses, hides, skins and semen (OIE, 2010). Given the potentially protracted duration of LSDV shedding into semen, even in animals that show no other obvious clinical signs during a herd outbreak, the possibility of semen from apparently healthy animals being contaminated with LSDV cannot be excluded. If frozen, such semen could also enter in vitro fertilization (IVF) systems where its potential to be transmitted via the resulting embryos is currently unknown. A recent study indicated that common semen processing methods are not sufficient to wash semen free of LSDV contamination (Annandale et al., 2018). In a previous study, LSDV DNA was detected in day 6 embryos flushed from heifers inseminated with fresh semen spiked with a high infective dose of LSDV (Annandale et al., 2014). To the authors' knowledge, no other studies have been published on the effect of LSDV on embryos, in either natural or IVP systems. Developing and documenting methods of rendering semen and embryos free from LSDV holds clear trade and economic advantages, and can assist in clarifying the risks of semen-based transmission of LSDV.

The objectives of this study were to investigate the effects of two different LSDV viral loads in cryopreserved semen on fertilization rate and yield of bovine blastocysts produced via an in vitro embryo production (IVEP) system, and to determine the viral status of embryos and culture fluids used during the process.

\section{Materials and methods}

\subsection{Study overview}

The detailed descriptions follow below, but briefly: Bovine oocytes were aspirated from ovaries collected from a local abattoir and split into three experimental groups (HD, LD and control). After maturation, the oocytes were incubated with frozen-thawed semen spiked with a high (HD) or a lower (LD) dose of LSDV, or with LSDV-free semen (control) in a conventional bovine IVF system. Normal IVEP processes were followed for all three experimental groups, with evaluation of blastocyst development on days 7 and 8 . After 
day 8 evaluation, PCR and virus isolation were performed on all remaining structures (i.e. blastocysts and oocytes/embryos that failed to develop), taking care to separate zonapellucida intact blastocysts from those that had already hatched. Several replicates were performed, until more than 350 oocytes per group had been used for IVF. After completion of the initial series of replicates, further replicates were performed to provide material for electron microscopy (EM) and embryo washing procedures. These samples were divided over two analyses; PCR was performed on one half, and either EM or washing was performed on the other half. The study was approved by the Animal Ethics Committee of the University of Pretoria (V093/16).

\subsection{Processing of semen samples}

Processed semen samples from a previous study (Annandale et al., 2018) were used. Briefly, semen was collected from a two year old Brahman bull, confirmed to be breeding sound and sero-negative for LSDV antibodies; the semen was confirmed negative for LSDV by PCR using validated primers (Bowden, Babiuk, Parkyn, Copps \& Boyle, 2008). The ejaculate was split into three equal volumes of $5 \mathrm{ml}$ and processed as follows: the HD sample was spiked with $2.5 \mathrm{ml}$ of viral suspension [LSDV Mireil isolate (Neethling strain) (V103/91)] suspended in minimum essential medium (MEM) (Biowest, Celtic Diagnostics, Cape Town, South Africa) at a titre of $4 \log \operatorname{TCID}_{50}$, the LD sample was spiked with $2.5 \mathrm{ml}$ of a $10^{3}$ dilution of the virus suspension, and $2.5 \mathrm{ml}$ of Triladyl ${ }^{\circledR}$ extender (Minitube, Tiefenbach, Germany) was added to the $C$ sample to equalize the volumes.

The three semen aliquots were processed for cryopreservation individually, making use of separate equipment to prevent cross-contamination. The control sample was processed first. Semen was frozen in $0.25 \mathrm{ml}$ French mini straws following the Standard Operating Procedures of the Section of Reproduction of the Faculty of Veterinary Science, University of Pretoria. Briefly, this involved extending the sample to a total of $15 \mathrm{ml}$ with Trilady ${ }^{\circledR}$; the volume required to produce straws with at least 20 million progressively motile sperm. Extended semen was equilibrated at $4^{\circ} \mathrm{C}$ for at least $2 \mathrm{hr}$, after which it was loaded into straws which were placed on a rack $4 \mathrm{~cm}$ above liquid nitrogen $\left(\mathrm{LN}_{2}\right)$ for 25 min. The straws were then plunged into $L_{2}$, packed and stored in $L N_{2}$ flasks until used. 


\subsection{Semen preparation for in vitro fertilization}

Preparation of semen for IVF was as previously described (Samardzija et al., 2006). Briefly, a single straw of semen from each of the three treatment groups was thawed by plunging it into a waterbath at $37^{\circ} \mathrm{C}$ for $40 \mathrm{~s}$, opened with sterile scissors, and emptied into an Eppendorf tube. Post-thaw motility of each sample was evaluated by placing a small drop $(5 \mu \mathrm{l})$ of semen on a pre-warmed $\left(37^{\circ} \mathrm{C}\right)$ coverslip on a glass slide and phase contrast microscopy under $200 \times$ magnification. Only semen samples with at least $30 \%$ post-thaw motility and $\geq 60 \%$ normal morphology were used. Thawed semen was then layered onto $2 \mathrm{ml}$ of the species-specific colloid, Bovipure ${ }^{\circledR}$ (Nidacon Laboratories AB, Göthenburg, Sweden) and centrifuged for $10 \mathrm{~min}$ at $150 \mathrm{~g}$. The resulting sperm pellet was re-suspended in Tyrode's albumin lactate pyruvate (TALP) medium (Merck, Modderfontein, South Africa). Before commencing the IVF trial, a sperm pellet from each of the experimental groups was tested for the presence of LSDV DNA by PCR; positive samples were subjected to virus isolation.

\subsection{In vitro embryo production}

In vitro embryo production was performed during autumn and winter, at a time when vector numbers would be low and therefore the risk that slaughtered cows may have been exposed to virus was low. A method established for the large-scale IVP of bovine embryos was used (Zullo et al., 2016), and is briefly described below. All media and reagents were obtained from Merck (Modderfontein, South Africa), unless otherwise specified.

Ovaries were harvested from cows immediately after slaughter at local abattoirs and placed in sterile polypropylene containers containing warm $\left(32-37{ }^{\circ} \mathrm{C}\right) 0.9 \%$ sodium chloride solution supplemented with $1 \%$ kanamycin, and transported to the laboratory in a warm insulated container. Ovaries were washed thoroughly to remove blood, after which the contents were aspirated from follicles between 3 and $8 \mathrm{~mm}$ in diameter. Cumulus-oocyte-complexes (COCs) thus recovered in follicular fluid within 4 hrs of slaughter were classified via stereomicroscopic assessment according to a standard system used in the laboratory (Gordon, 2003). Only Grade A and B oocytes were used for culture. In brief, oocytes were classified as Grade A when compact multilayered 
cumulus with homogenous ooplasm were present and the cytoplasm of the oocyte appeared light and transparent. Oocytes were classified as Grade B when observed to have had compact multilayered cumulus cells with homogenous ooplasm but with a coarse appearance and darker zone at the periphery of the oocyte while the cytoplasm appeared darker and less transparent. The pooled fluid containing the oocytes was confirmed to be free of BVDV using reverse transcription nested PCR, because BVDV is a known common contaminant in bovine IVF laboratories. Prior to maturation, groups of grade A and B COCs were washed at least three times in a hydroxyethylpiperazineethanesulfonic-buffered (HEPES) aspiration medium. Groups of 15-20 oocytes were transferred to pre-equilibrated (overnight) 4-well petri dishes (NUNC ${ }^{\mathrm{TM}}$; ThermoFisher Scientific, Johannesburg, South Africa) containing $380 \mu$ drops of TCM-maturation media under $400 \mu \mathrm{l}$ mineral oil at $39{ }^{\circ} \mathrm{C}$. Oocytes were matured at $39{ }^{\circ} \mathrm{C}$ for $24 \mathrm{hrs}$ in an atmosphere containing $5.5 \% \mathrm{CO}_{2}$ and saturated humidity. The temperature of media and work surfaces was maintained at a constant $38{ }^{\circ} \mathrm{C}$ during the entire procedure.

The frozen-thawed semen containing different viral loads (normal, HD \& LD) was used to fertilise separate groups of oocytes. Following maturation, oocytes were removed from the maturation dishes and washed at least three times in pre-equilibrated IVF (fertilisation) media under oil before they were transferred in approximately $10 \mu$ of media to $270 \mu \mathrm{l}$ fertilisation media drops under $400 \mu \mathrm{l}$ of mineral oil. Each drop containing 15-20 oocytes was inseminated using semen at a final concentration of $1 \times 10^{6}$ motile spermatozoa/mL (calculated by using the Neubauer haemocytometer-determined sample concentration, sperm motility and a dilution factor) and cultured for 22 hrs at $39{ }^{\circ} \mathrm{C}$ in a humidified atmosphere containing $5.5 \% \mathrm{CO}_{2}$.

Denuding putative zygotes of all cumulus cells and non-fertilizing sperm was accomplished by vortexing for $\leq 1 \mathrm{~min}$ in $300 \mu$ of TCM-HEPES in a $1 \mathrm{ml}$ Eppendorf vial. Denuded zygotes were recovered and rinsed twice before transfer to IVC-TALP drops. Fifteen to twenty putative zygotes were transferred into $270 \mu$ of IVC-TALP media droplets in 4-well dishes (NUNCTM; ThermoFisher Scientific) equilibrated overnight. Embryos were cultured in IVC-TALP in a modular chamber (Billups-Rothenberg) containing $5 \% \mathrm{CO}_{2}, 6 \% \mathrm{O}_{2}$ and balanced nitrogen at $39{ }^{\circ} \mathrm{C}$. Blastocyst formation was determined on days 7 and 8 , and grading of blastocysts performed based on the 
recommendations of the International Embryo Transfer Society (IETS) (Wright, 1998). Several runs were performed to account for intraculture confounding factors and to reach the required sample size.

\subsection{Samples collected for analysis}

The samples collected, and the diagnostic tests to which they were subjected, are summarized in Table 1. Samples were collected separately for each experimental group and IVEP run, and stored at $-80^{\circ} \mathrm{C}$ until analyzed.

\subsection{PCR analysis}

Samples were suspended in a $2 X$ lysis buffer (containing DTT) to which Proteinase $\mathrm{K}$ (included in the Qiagen ${ }^{\circledR}$ kit) was added, before incubation at $56^{\circ} \mathrm{C}$ overnight. The Qiagen ${ }^{\circledR}$ QIAmp DNA mini kit (Whitehead Scientific, Cape Town, South Africa) was subsequently used according to the manufacturer's instructions to extract viral DNA.

Real-time PCR was performed as described by Bowden (2008). Briefly, $2.5 \mu l$ of purified DNA was used in a real-time PCR Taqman assay. Primers (Lightcycler Taqman master kit; Roche Diagnostics, Mannheim, Germany) at a concentration of 20 pmol were used. These primers target an 89 bp region within the Capripoxvirus open reading frame 074 which encodes the intracellular mature virion protein, P32. Capripoxvirus-specific primers and probes had the following sequences: forward primer- CaPV074F1 5'-AAA ACG GTA TAT GGA ATA GAG TTG GAA-3', reverse primer- CaPV074R1 5'-AAA TGA AAC CAA TGG ATG GGA TA-3' and probe CaPV074P1 50-6FAM-TGG CTC ATA GAT TTC CT-MGBNFQ-3'. The reaction was carried out using a Light Cycler ${ }^{\circledR} 2.0$ (Roche Diagnostics, Mannhein, Germany) and the following program: A FastStart Taq. This involved a polymerase enzyme activation step of $10 \mathrm{~min}$ at $95^{\circ} \mathrm{C}$. The amplification consisted of 45 cycles of denaturation at $95^{\circ} \mathrm{C}$ for $10 \mathrm{~s}$, annealing at $60^{\circ} \mathrm{C}$ for $60 \mathrm{~s}$ and extension at $72{ }^{\circ} \mathrm{C}$ for $1 \mathrm{~s}$ (single acquisition mode). A cycle threshold ( $\mathrm{Ct}$ ) value of 40 cycles or more was deemed to be negative. The negative control consisted of water while the positive control was LSDV V103/91, extracted from cell culture material. 
Table 1 List of samples and diagnostic tests performed for detection of lumpy skin disease and bovine viral diarrhea virus at various stages of a bovine in vitro fertilization trial

\begin{tabular}{lll}
\hline Sample (pooled per IVEP run) & Diagnostic test & Infectious agent \\
\hline Frozen-thawed semen, post-processing & PCR and virus isolation & LSDV \\
\hline Fetal bovine serum used to supplement media & PCR and RT-nPCR & LSDV and BVDV \\
\hline Follicular fluid & PCR and RT-nPCR & LSDV and BVDV \\
\hline Fertilization media post denuding & PCR and virus Isolation & LSDV \\
\hline Unfertilized oocytes day 8 & PCR and virus isolation & LSDV \\
\hline Two-cell to morulae structures & PCR and virus isolation & LSDV \\
\hline Blastocysts & PCR and virus isolation & LSDV \\
\hline Hatched blastocysts & PCR and virus isolation & LSDV \\
\hline
\end{tabular}

Note: LSDV, lumpy skin disease virus; BVDV, bovine viral diarrhea virus; RT-nPCR, reverse transcription nested PCR

\subsection{Virus isolation}

Virus isolation was performed on LSDV PCR positive samples. Bovine dermis (BD) cells in $25 \mathrm{~cm}^{2}$ flasks were used and maintained in $10 \mathrm{ml}$ of MEM containing $5 \%$ foetal bovine serum (Biowest, Celtic Diagnostics, Cape Town, South Africa) and $1 \mathrm{ml}$ gentamycin (0.1 $\mathrm{mg} / \mathrm{ml}$ ) to prepare 96 -well plates (due to the small sample volumes) containing 480,000 cells per mililitre and incubated at $37{ }^{\circ} \mathrm{C}$ for $24 \mathrm{hrs}$ in an atmosphere of $5 \% \mathrm{CO}_{2}$ in air. Semen samples were inoculated directly onto the cell monolayers. Cell cultures were observed daily for cytopathic effects (CPE). After 14 days, cultures showing no CPE were frozen briefly at $-70^{\circ} \mathrm{C}$ and then thawed. A second passage was performed and each culture was observed for a further 14 days. A third passage was performed for these samples. A cell monolayer without any virus was used as negative control while a cell monolayer inoculated with $0.2-0.5 \mathrm{ml}$ of an LSDV (strain V103/91) suspension at a titre of $4 \log$ TCID $_{50}$ was used as positive control.

\subsection{Electron microscopy}

In preparation for transmission EM, embryos in $100 \mu \mathrm{l}$ of media were fixed overnight with an equal volume of $2.5 \%$ phosphate buffered glutaraldehyde. The samples were washed in $0.075 \mathrm{M}$ phosphate buffer, $\mathrm{pH} 7.4$ before post-fixation in $1 \%$ osmium tetroxide for $1 \mathrm{hr}$. After two subsequent washes, the samples were dehydrated through a graded ethanol series $(50 \%, 70 \%, 80 \%, 90 \%, 96 \%, 100 \%)$ and embedded in epoxy resin. Ultrathin 
sections of the embryos were stained with lead citrate and uranyl acetate before viewing using a Philips CM10 transmission electron microscope (Philips Electron Optical Division, Eindhoven, The Netherlands) operated at $80 \mathrm{kV}$.

\subsection{Statistical analysis}

Data were analysed using STATA 14 (StataCorp, College Station, Texas). Multivariable mixed effects Poisson or negative binomial regression models were used for count data (number of antral follicles, numbers of COCs harvested and numbers of COCs and embryos reaching certain developmental stages during the IVEP procedure). Time duration of aspiration and oocyte processing, quality of oocytes (expressed as the ratio of Grade A to Grade B oocytes) and effective sperm concentration (linear motility x sperm concentration) were included as covariates in the models. Overdispersion in the Poisson model was assessed by fitting the equivalent negative binomial regression model with the overdispersion parameter $\alpha$ and using a likelihood ratio test to examine the null hypothesis that $\alpha=0$ (Dohoo, Martin \& Stryhn, 2009). Statistical significance was set at $5 \%$.

\section{Results}

\subsection{Embryo production parameters}

The embryo production parameters for the three experimental groups are summarized in Table 2. In seven IVEP replicates, a total of 1,252 oocytes were inseminated (410 in the control group, 480 in the HD group and 362 in the LD group). A total of 346 (84.4\%), $376(78.3 \%)$ and 249 (68.8\%) oocytes cleaved in the control, HD and LD groups respectively, while corresponding blastocyst production was 154 (37.6\%), 107 (22.3\%) and $61(16.9 \%)$. A further three runs, producing 44 blastocysts, were performed to provide samples for PCR confirmation of the presence of viral DNA (10 embryos), embryo washing (10 embryos) and EM examination (24 embryos). 
Table 2 Embryo production parameters for the three experimental bovine IVF groups that differed by lumpy skin disease virus load in semen used for fertilization

\begin{tabular}{|c|c|c|c|c|c|}
\hline $\begin{array}{l}\text { Group and } \\
\text { run }\end{array}$ & $\begin{array}{c}\text { Oocytes } \\
\text { inseminated }\end{array}$ & $\begin{array}{l}\text { Oocytes } \\
\text { cleaved }\end{array}$ & $\begin{array}{l}\text { Cleavage } \\
\text { rate }(\%)^{\S}\end{array}$ & $\begin{array}{c}\text { Day } 8 \\
\text { blastocysts }\end{array}$ & $\begin{array}{l}\text { Blastocyst } \\
\text { rate }(\%)^{\S}\end{array}$ \\
\hline Control 1 & 38 & 36 & 94.7 & 24 & 63.2 \\
\hline Control 2 & 54 & 46 & 85.2 & 31 & 57.4 \\
\hline Control 3 & 44 & 39 & 88.6 & 17 & 38.6 \\
\hline Control 4 & 36 & 25 & 67.6 & 7 & 18.9 \\
\hline Control 5 & 98 & 81 & 81.0 & 32 & 32.0 \\
\hline Control 6 & 90 & 79 & 87.8 & 28 & 31.1 \\
\hline Control 7 & 50 & 40 & 80.0 & 15 & 30.0 \\
\hline Control total & 410 & 346 & $84.4^{a}$ & 154 & $37.6^{a}$ \\
\hline HD 1 & 37 & 34 & 89.5 & 9 & 23.7 \\
\hline HD 2 & 51 & 35 & 64.8 & 0 & 0.0 \\
\hline HD 3 & 40 & 32 & 72.7 & 18 & 40.9 \\
\hline HD 4 & 38 & 32 & 84.2 & 13 & 34.2 \\
\hline HD 5 & 109 & 87 & 79.8 & 20 & 18.3 \\
\hline HD 6 & 90 & 67 & 74.4 & 27 & 30.0 \\
\hline HD 7 & 115 & 89 & 77.4 & 20 & 17.4 \\
\hline HD $^{\ddagger}$ total & 480 & 376 & $78.3^{a}$ & 107 & $22.3^{b}$ \\
\hline LD 1 & 17 & 14 & 36.8 & 2 & 5.3 \\
\hline LD 2 & 54 & 36 & 66.7 & 16 & 29.6 \\
\hline LD 3 & 44 & 34 & 77.3 & 13 & 29.5 \\
\hline LD 4 & 34 & 25 & 67.6 & 6 & 16.2 \\
\hline LD 5 & 105 & 66 & 61.1 & 10 & 9.3 \\
\hline LD 6 & 60 & 38 & 63.3 & 9 & 15.0 \\
\hline LD 7 & 48 & 36 & 75.0 & 5 & 10.4 \\
\hline $\operatorname{LD}^{\dagger}$ total & 362 & 249 & $68.8^{b}$ & 61 & $16.9^{b}$ \\
\hline
\end{tabular}

Note: IVF, in vitro fertilization; LD, lower dose; HD, high dose

${ }_{\text {High LSD viral load }}$

${ }^{\dagger}$ Lower LSD viral load

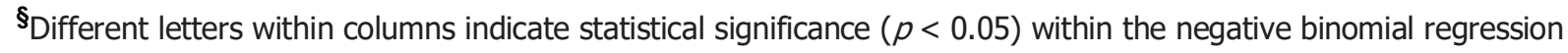
model

\subsection{Viral status of media and embryos}

All the frozen-thawed semen samples from the control experimental group tested negative, while samples from the HD and LD group tested consistently positive, with $\mathrm{Ct}$ values between $25.3-28.1$ and 35.3-37.0, respectively. The viral status of media and 
embryos for the three experimental groups are summarized in Table 3, while the Ct values of the positive samples are represented in Table 4. All follicular fluid samples and serum used in media tested negative for LSDV DNA and BVDV RNA. No LSD viral DNA was found in the control or LD groups in any of the samples collected. In the HD group, viable LSDV and viral DNA was found in all fertilization media and in some unfertilized oocytes, zygotes, morulae, blastocysts and hatched blastocysts. A batch of 10 embryos tested positive for LSD viral DNA, while the 10 washed embryos tested negative. Viable virus could be identified by virus isolation in all samples that tested PCR positive.

\subsection{Electron microscopy}

LSDV virions, with a size of 200-300 nm and a double-layered envelope, could be seen in some hatched and unhatched day 8 blastocysts (Figure 1). The virion morphology was indicative of viral replication and evidence of cell death and embryo architecture destruction could also be seen.

\subsection{Oocyte cleavage and blastocyst production}

There was significant overdispersion in the Poisson regression model, indicating that the negative binomial model better fitted the data distribution, and hence the latter was used. Oocyte cleavage success was significantly lower [count ratio $(C R)=0.77 ; 95 \%$ CI: 0.65 $0.92 ; p=0.003$ ] in the LD group when compared to the control group. This lower cleavage rate was not related to any other potential predictor variables (duration of processing, quality of oocytes, progressive sperm motility and sperm concentration) in the model. The success of blastocyst production was significantly lower in the HD group (CR $=0.64 ; 95 \%$ CI: $0.42-0.99 ; p=0.043$ and LD groups $\mathrm{CR}=0.55 ; 95 \% \mathrm{CI}$ : $0.34-$ $0.89 ; p=0.015)$ compared to the control group. PCR positivity for LSDV was not a significant predictor of blastocyst count $(p=0.107)$. A random effect for date added to the model to account for clustering was not significant and did not influence the results. 
Table 3 Viral status of media and embryos after in vitro production of bovine embryos using semen spiked with lumpy skin disease virus

\begin{tabular}{lcccccccccccccccc}
\hline & \multicolumn{3}{c}{$\begin{array}{c}\text { Fertilization } \\
\text { media }\end{array}$} & \multicolumn{3}{c}{ Unfertilized } & \multicolumn{3}{c}{$\begin{array}{c}\text { 2-cell to } \\
\text { morula }\end{array}$} & \multicolumn{3}{c}{ Blastocysts } & \multicolumn{3}{c}{$\begin{array}{c}\text { Hatched } \\
\text { blastocysts }\end{array}$} \\
Run & Ctrl & LD $^{\dagger}$ & HD $^{\ddagger}$ & Ctrl & LD & HD & Ctrl & LD & HD & Ctrl & LD & HD & Ctrl & LD & HD \\
\hline 1 & - & - & + & - & - & - & - & - & - & - & - & - & - & - & - \\
2 & - & - & + & - & - & - & - & - & - & - & - & - & - & - & - \\
3 & - & - & + & - & - & - & - & - & - & - & - & - & - & - & - \\
4 & - & - & + & - & - & + & - & - & + & - & - & + & - & - & + \\
5 & - & - & + & - & - & + & - & - & + & - & - & + & - & - & + \\
6 & - & - & + & - & - & + & - & - & + & - & - & + & - & - & + \\
7 & - & - & + & - & - & - & - & - & - & - & - & - & - & - & - \\
\hline
\end{tabular}

${ }^{\dagger}$ Lower LSD viral load

$\ddagger_{\text {High LSD viral load }}$

Table 4 Cycle threshold $(\mathrm{Ct})$ values of samples positive for lumpy skin disease virus DNA in the HD group

\begin{tabular}{|cccccc}
\hline Run & $\begin{array}{c}\text { Fertilization } \\
\text { media }\end{array}$ & Unfertilized & $\begin{array}{c}\text { 2-cell to } \\
\text { morula }\end{array}$ & Blastocysts & $\begin{array}{c}\text { Hatched } \\
\text { blastocysts }\end{array}$ \\
\hline $\mathbf{1}$ & 33.15 & - & - & - & - \\
\hline $\mathbf{2}$ & 32.55 & - & - & - & - \\
\hline $\mathbf{3}$ & 34.54 & - & - & - & - \\
\hline $\mathbf{4}$ & 30.87 & 34.17 & 29.67 & 32.79 & 32.08 \\
\hline $\mathbf{5}$ & 31.96 & 31.65 & 31.32 & 30.08 & 31.10 \\
\hline $\mathbf{6}$ & 31.72 & 28.26 & 31.72 & 28.69 & 28.27 \\
\hline $\mathbf{7}$ & 34.21 & - & - & - & - \\
\hline
\end{tabular}




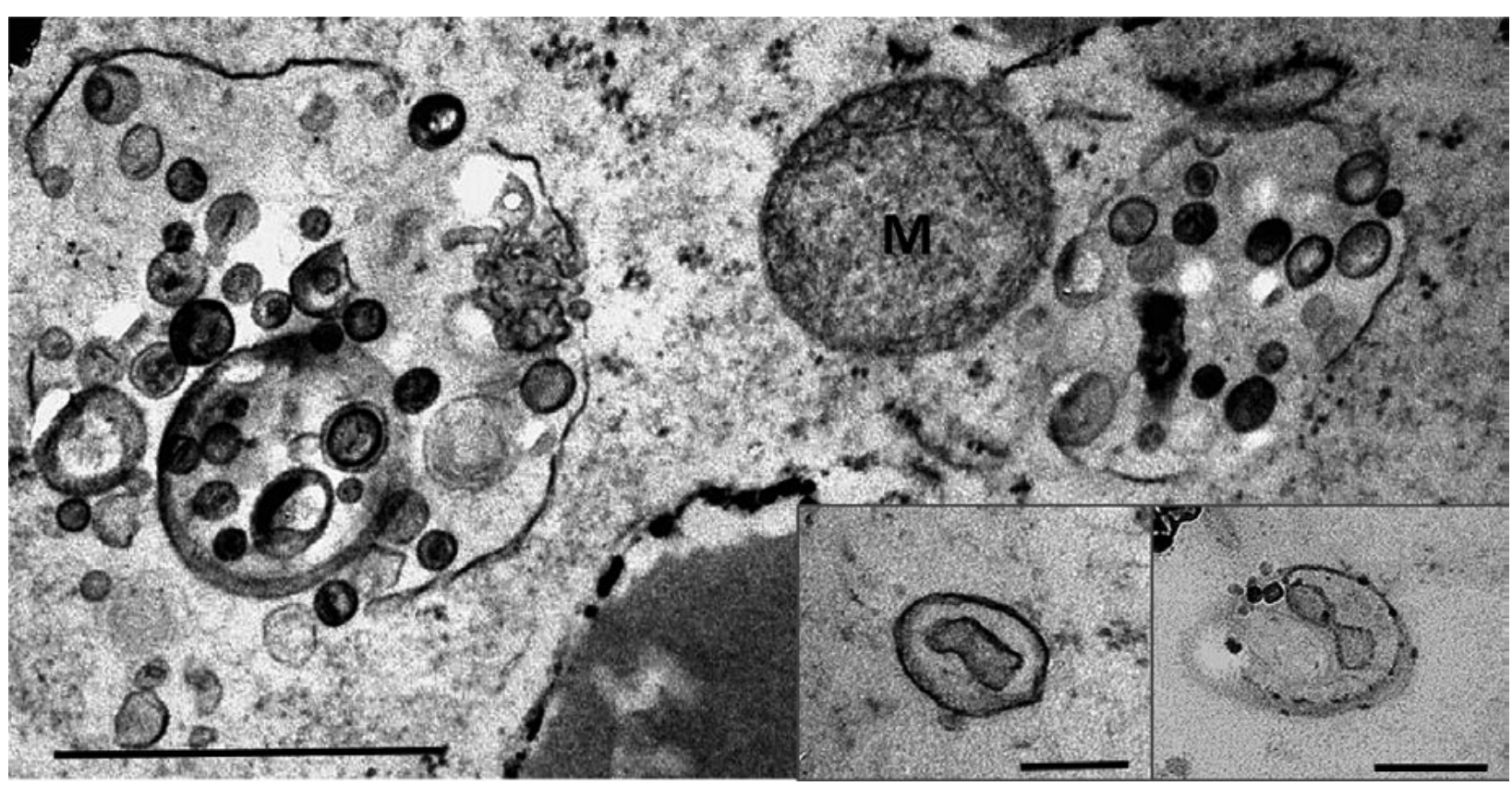

Figure 1 Numerous virus particles in various stages of development visible on both sides of a mitochondrion $(M)$ within a bovine embryonic cell; bar $=1 \mathrm{~m}$. Inset: Two free-lying virus particles displaying the more typical morphology of the mature virion; bars $=0.25 \mu \mathrm{m}$

\section{Discussion}

In this study, embryo yield was significantly reduced by the presence of LSDV in frozenthawed semen used in an IVEP system, irrespective of the viral dose. In cases where semen with the lower viral dose was used, significantly reduced oocyte cleavage rates were observed. Lumpy skin disease virus could be demonstrated in fertilization media, unfertilized oocytes, degenerate embryos, blastocysts and hatched blastocysts when higher doses of LSDV were present in the frozen-thawed semen used for IVF.

Our findings of poorer embryo production parameters when using LSDV contaminated semen for IVF were similar to what has been reported for the use of BHV-1 contamined semen (Bielanski \& Loewen, 1994), but different to the reported effects for BHV-5 contaminated semen (Silva-Frade, Martins, Borsanelli \& Cardoso, 2010). Failure of BLVinfected semen or oocytes to negatively affect embryo production has also been reported (Bielanski, Maxwell \& Simard, 2000). Conflicting reports exist in the literature regarding the effect of use of semen contaminated with BVDV on embryo development. Bielanski (1994) and Guerin (1992) reported a negative effect, whereas Da Silva Cardoso Pinto 
(2017) reported no adverse effect on embryo development.

Since PCR results at the blastocyst stage were not significantly associated ( $p=0.107)$ with blastocyst rate, it suggests the negative effect of LSDV on blastocyst development occurred earlier in embryo production processes and the virus did not exert its effect principally on the blastocyst at the formation stage. The finding of positive PCR and virus isolation results for the HD group only, suggests a viral dose effect of LSDV in IVEP systems. Dilution of semen in preparation for IVF likely reduced the viral dose in the LD group to levels just above the detection limit of the PCR assay whereas, subsequent to denuding, it apparently dropped below the detection limit. The $\mathrm{Ct}$ values of frozenthawed semen samples within the LD group (35.3-37.0) support this statement. It is known that LSDV associates with sperm membranes (Annandale et al., 2018) and we postulate that, at low concentrations, the virus in the fertilization media may associate with the cumulus cells surrounding the putative zygotes. The degree of denuding and removing the cumulus cells, sperm and debris from the fertilization media, presumably determined the residual viral load at PCR. It should also be considered that seminal plasma constituents are known to limit the sensitivity of diagnostic tests for detecting infectious agents (Bagla, Osuagwuh, Annandale, Irons \& Venter, 2006) and could, at a low level of virus contamination, have negatively affected the sensitivity of the assays.

The PCR finding that blastocysts and hatched blastocysts were infected with LSD viralDNA suggests that the virus associates with or enters the embryo, where it could affect early embryonic viability. Evidence for this was further supported by the EM findings. It therefore appears that LSDV does not simply associate with or adhere to the zona pellucida, as is the case for Tritrichomonas foetus (Bielanski, Ghazi \& Phipps-Toodd, 2004), Neospora caninum (Bielanski, Robinson \& Phipps-Todd, 2002) and BTV (Venter, Gerdes, Wright \& Terblanche, 2011). It is noteworthy that embryonic structures only tested positive for LSDV by PCR if the Ct value of fertilization media was < 32.5 cycles; however, the experimental design did not allow statistical testing of this relationship. While it has been established that LSDV-spiked semen can trigger clinical LSD in heifers and infect in vivo derived ZP-intact embryos (Annandale et al., 2014), it is not known whether the results of experimental infections are applicable to field conditions. Clear differences between in vivo and in vitro derived embryos, especially regarding the ability 
of embryo washing procedures to remove viruses (Wrathall et al., 2006) have been shown, indicating that caution is required when extrapolating IVEP findings to natural conditions.

The effect of transferring LSDV infected embryos to recipient cows is not known. Bielanski (2000) reported that when unwashed in vivo produced embryos positive for BHV-1 were transferred to seronegative cows, poor pregnancy rates and seroconversion resulted (Bielanski, Algire, Lalonde \& Garceac, 2013b). In another experiment, the same authors found that if BVDV-infected embryos were washed according to the IETS disinfection protocol prior to transfer, they did not trigger seroconversion in either the cows or their offspring (Bielanski, Algire, Lalonde \& Garceac, 2013a). Wrathall (2006), quoting Bielanski (2000), concluded that while the use of BLV-infected semen in IVEP could result in infected embryos, the likelihood of transmission of BLV to recipients was very small. In two separate experiments, one using semen infected with BTV (Thomas, Singh \& Hare, 1985) and the other infecting heifers with BTV and collecting embryos from viraemic cows (Acree et al., 1991), it was shown conclusively that the IETS washing protocol reduced the risk of transmission of BTV to negligible. Since the current experimental design resulted in low numbers of embryos available for IETS washing, its effect on embryos infected with LSDV still needs investigation.

It is noteworthy that the cleavage and blastocyst rates between individual IVF embryo runs showed a substantial range (67.6\%-94.7\% \& 18.9\%-63.2\% for control; 64.8\%89.5\% \& 0\%-40.9\% for HD; and 36.8\%-75.0\% \& 5.3\%-29.6\% LD experimental groups). While variation between individual replicates within IVEP systems has been described, other factors potentially impacting on embryo production parameters should also be considered. BVDV is often considered a low-level contaminant within IVEP systems, although there was no evidence of BVDV contamination in the current study. While performing the experiment in the winter months should have reduced the risk of introducing other viruses, this possibility cannot be excluded entirely.

Due to the variety of experimental models described, caution should be applied when comparing transmission of virus to embryos, and the results of embryo washing. The experimental models range from use of fresh semen from infected bulls (Thibier \& Nibart, 
1987), to frozen-thawed semen from naturally infected (persistently infected with BVDV) bulls (Guerin et al., 1992), artificially spiked frozen-thawed semen (Schlafer et al., 1990), incubation of oocytes with virus (Bielanski, Simard, Maxwell \& Nadin-Davis, 2001) and co-incubation of virus with morulae or embryos (Waldrop et al., 2002). Some of the experiments were carried out within an in vitro setting, while others were performed on live animals and in vivo embryo development. These experimental models therefore address different aspects of the possible mechanism of virus transmission within the reproductive system and comparison of their results may not necessarily be scientifically valid.

In conclusion, the presence of LSDV in frozen-thawed semen negatively affected embryo yield in IVEP systems. Moreover, the presence of the virus within day 8 blastocysts confirmed that embryo transfer carries a potential risk of virus transmission in cattle. Further research to quantify this potential risk is indicated.

\section{Conflict of interest}

The authors declare no conflict of interest

\section{ORCID}

Cornelius Henry Annandale $\quad$ https://orcid. org/0000-0002-0525-8954 


\section{References}

Acree J A, Echternkamp S E, Kappes S M, Luedke A J, Holbrook F R, Pearson J E, Ross G S. 1991. Failure of embryos from bluetongue infected cattle to transmit virus to susceptible recipients or their offspring. Theriogenology. 36, 689-697. https://doi.org/10.1016/0093691X(91)90406-4

Annandale C H, Holm D E, Ebersohn K, Venter E H. 2014. Seminal transmission of lumpy skin disease virus in heifers. Transboundary and Emerging Diseases. 61, 443-448. https://doi.org/10.1111/ tbed.12045

Annandale C H, Irons P C, Bagla V P, Osuagwuh U I, Venter E H. 2010. Sites of persistence of lumpy skin disease virus in the genital tract of experimentally infected bulls. Reproduction in Domestic Animals. 45, 250-255. https://doi. org/10.1111/j.1439-0531.2008.01274.x

Annandale C H, Smuts M P, Ebersohn K, Du Plessis L, Venter E H, Stout T A E. 2018. Effect of semen processing methods on lumpy skin disease virus status in cryopreserved bull semen. Animal Reproduction Science. 195, 24-29. https://doi.org/10.1016/j.anireprosci. 2018.04.080

Babiuk S, Bowden T R, Parkyn G, Dalman B, Manning L, Neufeld J, Embury-Hyatt C, Copps J, Boyle, D B. 2008. Quantification of lumpy skin disease virus following experimental infection in cattle. Transboundary and Emerging Diseases. 55, 299-307. https://doi. org/10.1111/j.1865-1682.2008.01024.x

Bagla V P, Osuagwuh U I, Annandale C H, Irons P C, Venter E H. 2006. Elimination of toxicity and enhanced detection of lumpy skin disease virus on cell culture from experimentally infected bovine semen samples. Onderstepoort Journal of Veterinary Research. 73, 263268.

Beard P M. 2016. Lumpy skin disease: A direct threat to Europe. Veterinary Record. 178, 557558. https://doi.org/10.1136/vr.i2800

Bielanski A, Algire J, Lalonde A, Garceac A. 2013a. Embryos produced from fertilization with bovine viral diarrhea virus (BVDV)-infected semen and the risk of disease transmission to embryo transfer (ET) recipients and offspring. Theriogenology. 80, 451-455. https://doi.org/10.1016/j.theriogenology.2013.04.028

Bielanski A, Algire J, Lalonde A, Garceac A. 2013b. Prevention of bovine herpesvirus-1 transmission by the transfer of embryos disinfected with recombinant bovine trypsin. Theriogenology. 80, 1104-1108. https://doi.org/10.1016/j.theriogenology.2013.08.012

Bielanski A, Ghazi D F, Phipps-Todd B. 2004. Observations on the fertilization and development of preimplantation bovine embryos in vitro in the presence of Tritrichomonas foetus. Theriogenology. 61, 821-829. https://doi.org/10.1016/S0093-691X(03)00229-2

Bielanski A, Loewen K. 1994. In vitro fertilization of bovine oocytes with semen from bulls persistently infected with bovine viral diarrhea virus. Animal Reproduction Science. 35, 183-189. https://doi.org/10.1016/0378-4320(94)90034-5 
Bielanski A, Maxwell P, Simard C. 2000. Effect of bovine leukaemia virus on embryonic development and association with in vitro fertilised embryos. Veterinary Record. 146, 255256. https://doi.org/10.1136/vr.146.9.255

Bielanski A, Robinson J, Phipps-Todd, B. 2002. Effect of Neospora caninum on in vitro development of preimplantation stage bovine embryos and adherence to the zona pellucida. Veterinary Record. 150, 316-318. https://doi.org/10.1136/vr.150.10.316

Bielanski A, Simard C, Maxwell P, Nadin-Davis S. 2001. Bovine immunodeficiency virus in relation to embryos fertilized in vitro. Veterinary Research Communications. 25, 663-673. https://doi.org/10.1023/A:1012795214250

Bowden T R, Babiuk S L, Parkyn G R, Copps J S, Boyle D B. 2008. Capripoxvirus tissue tropism and shedding: A quantitative study in experimentally infected sheep and goats. Virology. 371, 380-393. https://doi.org/10.1016/j.virol.2007.10.002

Coetzer J A W. 2004. Lumpy skin disease. In: Coetzer J A W, Tustin R C (Eds.), Infectious diseases of livestock. Vol. 2, $2^{\text {nd }}$ ed. Oxford University Press, Cape Town, South Africa. 1268-1276.

Da Silva Cardoso Pinto V, Alves M F, De Souza Nunes Martins M, Basso A C, Tannura J H, Pontes J H F, Pituco E M. 2017. Effects of oocytes exposure to bovine diarrhea viruses BVDV-1, BVDV-2 and Hobi-like virus on in vitro-produced bovine embryo development and viral infection. Theriogenology. 97, 67-72. https://doi.org/10.1016/j.theriogenology.2017. 04.028

Dohoo I, Martin W, Stryhn H. 2009. Veterinary Epidemiologic Research, $2^{\text {nd }}$ ed. Charlottetown, Prince Edward Island, Canada: VER Inc.

Gordon I R. 2003. Laboratory production of cattle embryos, $2^{\text {nd }}$ ed. International, Wellingford, Oxon, UK: C.A.B. https://doi.org/10.1079/9780851996660.0000

Guerin B, Chaffaux S, Le Guienne B, Allietta M, Thibier M. 1992. IVF and IV culture of bovine embryos using semen from a bull persistently infected with BVD. Theriogenology. 37, 217. https://doi.org/10.1016/0093-691X(92)90286-Z

Irons P C, Tuppurainen E S M, Venter E H. 2005. Excretion of lumpy skin disease virus in bull semen. Theriogenology. 63, 1290-1297. https://doi.org/10.1016/j.theriogenology.2004. 06.013

OIE. 2010. Chapter 2.4.14, Lumpy skin disease. In: Manual of diagnostic tests and vaccines for terrestrial animals. Paris, France: OIE.

Prozesky L, Barnard B J H. 1982. A study of the pathology of lumpy skin disease in cattle. Onderstepoort Journal of Veterinary Research. 49, 167-175.

Rouby S, Aboulsoud E. 2016. Evidence of intrauterine transmission of lumpy skin disease virus. Veterinary Journal. 209, 193-195. https://doi.org/10.1016/j.tvjl.2015.11.010

Samardzija M, Karadjole M, Matkovic M, Cergolj M, Getz I, Dobranic T, Tomaskovic A, Petric J, Surina J, Grizelj J, Karadjole T. 2006. A comparison of BoviPure ${ }^{\circledR}$ and Percoll ${ }^{\circledR}$ on bull sperm separation protocols for IVF. Animal Reproduction Science. 91, 237-247. https://doi.org/10.1016/j.anireprosci.2005.04.005 
Schlafer D H, Gillespie, J H, Foote R H, Quick S, Pennow N N, Dougherty E P. 1990. Experimental transmission of bovine viral diseases by insemination with contaminated semen or during embryo transfer. Deutsche Tierärztliche Wochenschr. 97, 68-72.

Silva-Frade C, Martins A Jr, Borsanelli A C, Cardoso T C. 2010. Effects of bovine Herpesvirus Type 5 on development of in vitro-produced bovine embryos. Theriogenology. 73, 324331. https://doi.org/10.1016/j.theriogenology.2009.09.016

Thibier M, Nibart M. 1987. Disease control and embryo imports. Theriogenology. 27, 37-47. https://doi.org/10.1016/0093-691X(87)90068-9

Thomas F C, Singh EL, Hare W C D. 1985. Embryo transfer as a means of controlling viral infections. VI. Bluetongue virus-free calves from infectious semen. Theriogenology. 24, 345-350. https://doi.org/10.1016/0093-691X(85)90226-2

Tuppurainen E S M, Oura C A L. 2012. Review: Lumpy skin disease: An emerging threat to Europe, the Middle East and Asia. Transboundary and Emerging Diseases. 59, 40-48. https://doi.org/10.1111/j.1865-1682.2011.01242.x

Tuppurainen E, Oura C. 2014. Lumpy skin disease: An African cattle disease getting closer to the EU. Veterinary Record. 175, 300-301. https://doi.org/10.1136/vr.g5808

Tuppurainen E S M, Venter E H, Shisler J L, Gari G, Mekonnen G A, Juleff N, Lyons N A, De Clercq K, Upton C, Bowden T R, Babiuk S, Babiuk L A. 2017. Review: Capripoxvirus diseases: Current status and opportunities for control. Transboundary and Emerging Diseases. 64, 729-745. https://doi.org/10.1111/tbed.12444

Venter E H, Gerdes T, Wright I, Terblanche J. 2011. An investigation into the possibility of bluetongue virus transmission by transfer of infected ovine embryos. Onderstepoort Journal of Veterinary Research. 78, 1.

Waldrop J G, Stringfellow D A, Givens M D, Riddell K P, Galik P, Riddell M G. 2002. Association of bovine viral diarrhea virus (BVDV) with artificiall exposed, in vivo-derived, bovine mebryos varies between different viral strains. Theriogenology. 57, 575.

Wrathall A E, Simmons H A, Van Soom A. 2006. Evaluation of risks of viral transmission to recipients of bovine embryos arising from fertilisation with virus-infected semen. Theriogenology. 65, 247-274. https://doi.org/10.1016/j.theriogenology.2005.05.043

Wright J M. 1998. Photographic illustrations of embryo development stages and quality codes. In: Stringfellow D A, Siedel S M (Eds.), Manual of the International Embryo Transfer Society. 167-170. Savoy: IETS.

Zullo G, De Canditiis C, Pero M E, Albero G, Salzano A, Neglia G, Campanile G, Gasparrini B. 2016. Crocetin improves the quality of in vitro-produced bovine embryos: Implications for blastocyst development, cryotolerance, and apoptosis. Theriogenology. 86, 1879-1885. https://doi.org/10.1016/j.theriogenology.2016.06.011 


$$
5
$$




\section{Chapter 5}

\section{Effect of semen processing methods on lumpy skin disease virus status in cryopreserved bull semen}

C Henry Annandale ${ }^{a,}{ }^{*}$, Mario P Smuts ${ }^{a}$, Karen Ebersohn ${ }^{b}$, Lizette du Plessis ${ }^{c}$, Estelle H Venter ${ }^{b, d}$, Tom A E Stout ${ }^{a, e}$

aDepartment of Production Animal Studies, Faculty of Veterinary Science, University of Pretoria, Onderstepoort, South Africa

bDepartment of Veterinary Tropical Diseases, Faculty of Veterinary Science, University of Pretoria, Onderstepoort, South Africa

'Department of Anatomy and Physiology, Faculty of Veterinary Science, University of Pretoria, Onderstepoort, South Africa

'School of Public Health, Medical and Veterinary Sciences, Discipline: Veterinary Science, James Cook University, Townsville, Australia

eDepartment of Equine Sciences, Faculty of Veterinary Medicine, Utrecht University, Utrecht, Netherlands 


\section{Abstract}

Lumpy skin disease is an economically important disease of cattle, caused by the lumpy skin disease virus (LSDV; Capripoxvirus). It has a variable clinical appearance but, in severely affected animals, is associated with extensive skin damage, pneumonia and death. The LSDV can be found in the semen of infected bulls for prolonged periods of time, from where it can be transmitted by mating or artificial insemination and cause clinical disease in heifers and cows. In this study, an ejaculate was collected from a LSDV seronegative bull and confirmed free from LSDV DNA by PCR. The ejaculate was split into a control sample (C), a sample spiked with a 4 log TCID 50 dose of an LSDV isolate (HD) and a $10^{3}$ dilution of the virus suspension (ND) and frozen routinely. Two straws from each of the different semen treatment groups (HD, ND \& $C$ ) were subsequently thawed and subjected to swim-up, single layer centrifugation, Percoll ${ }^{\circledR}$ density gradient and a Percoll ${ }^{\circledR}$ density gradient with added trypsin. For one set of straws, semen quality variables were recorded, and viral DNA status determined using PCR; the other set was used for positive staining electron microscopy. Samples determined to be positive for LSDV DNA by PCR were then subjected to virus isolation (VI). Complete elimination of LSDV from semen did not occur with use of any of the processing methods. Trypsin did reduce the viral load, and eliminated LSDV from the ND sample, but severely negatively influenced semen quality. The LSDV virions, as assessed by electron microscopy, were associated with the sperm plasma membrane. Further investigation is needed to establish the efficacy of immuno-extenders for rendering semen free from LSDV. 


\section{Introduction}

Lumpy skin disease (LSD) is a viral disease of cattle caused by the lumpy skin disease virus (LSDV), a member of the genus Capripoxvirus. It is common in Africa and, more recently has been detected in the Middle East where it is associated with fever, lachrymation, lymphadenopathy, nodules on the skin and internal organs, weight loss, inappetence and, in rare cases, pneumonia and death (Coetzer, 2004). In countries where it is present, LSD is associated with significant economic losses attributed to the extensive damage to hides, loss of production and restrictions to trade (Babiuk et al., 2008a). In recent years outbreaks have occurred in Egypt (OIE, 2006), Israel (Brenner et al., 2009), Greece (Tasioudi et al., 2016), Azerbaijan (Zeynalova et al., 2016), Jordan (Abutarbush et al., 2015) and Iraq (Al-Salihi \& Hassan, 2015). The LSDV is a direct threat to Europe and Great Britain (Tuppurainen \& Oura, 2014; Beard, 2016). The origin of the outbreaks remains mostly unknown, but illegal movement of farm animals without proper health assessments and the collapse of veterinary services due to political uncertainty have been implicated (Tuppurainen et al., 2017).

Several transmission routes for LSD infection have been identified, mostly associated with mechanical transmission via blood-sucking insects (Carn \& Kitching, 1995; Chihota et al., 2001) and ticks (Tuppurainen et al., 2013). Even though seminal transmission of LSDV to heifers has been demonstrated experimentally (Annandale et al., 2014), and a case of intrauterine transmission has been reported (Rouby \& Aboulsoud, 2016), the potential for reproductive transmission of LSDV has not been determined.

Cattle that become infected with LSDV, experimentally and naturally, have variable clinical signs; ranging from almost none to severe generalized lumpy skin disease. The LSDV can be shed in the semen of experimentally infected bulls for up to 159 days (Irons et al., 2005), however, the nature of this shedding is not well-documented. Semen shedding of the virus mirrors the clinical syndrome with the amount, quantity and duration of shedding being highly variable and difficult to predict (Babiuk et al., 2008b; Annandale et al., 2010). 
In countries free of LSDV, import restrictions apply to livestock, carcasses, hides, skins and semen (OIE, 2010). Given the potentially protracted duration of LSDV shedding into semen, even in animals that have no other obvious clinical signs during a herd outbreak, the likelihood of semen being contaminated with LSDV cannot be excluded. If frozen, such semen could also enter in vitro fertilization systems where its potential to be transmitted via resulting embryos is currently unknown. Developing and documenting methods of rendering semen and embryos free from LSDV has trade and economic advantages, and can assist in clarifying the risks of semen-based transmission of LSDV.

The objective of this study was to investigate the ability of common semen processing techniques to remove lumpy skin disease virus from cryopreserved bull semen. As a secondary objective, the way in which the virus associates with the sperm cell was also investigated.

\section{Materials and methods}

\section{$2.1 \quad$ Study overview}

Semen was collected from a two year old Brahman bull, confirmed to be breeding sound and sero-negative for LSDV; the semen was confirmed negative for LSDV by polymerase chain reaction (PCR) with validated primers. The semen sample was split into three aliquots, two of which were spiked with a large (LD) and small dose (SD) of LSDV, respectively, while the third portion served as a control (C). All three aliquots were processed and frozen in $0.25 \mathrm{ml}$ French mini straws. Two sets of straws from each of the different experimental groups (HD, ND \& $)$ ) were subsequently thawed and subjected to swim-up, single layer centrifugation, Percol ${ }^{\circledR}$ density gradient and a Percoll ${ }^{\circledR}$ density gradient with added trypsin. For one set of straws, semen quality variables were recorded and viral DNA status determined using PCR. Samples found to be positive for LSDV DNA by PCR were then subjected to virus isolation (VI). For the other set of straws, positive staining electron microscopy was performed, after the various semen processing methods. The study was approved by the Animal Ethics Committee of the University of Pretoria (V093/16). 


\subsection{Spiking of semen samples with virus}

The LSDV Mireil isolate (Neethling strain) (V103/91) was obtained from the Virology Section of the Department of Veterinary Tropical Diseases and suspended in Minimum Essential Medium (MEM; Biowest, Celtic Diagnostics, Cape Town, South Africa). The ejaculate was split into three equal volume aliquots of $5 \mathrm{ml}$ each and processed as follows: the LD sample was spiked with $2.5 \mathrm{ml}$ of the viral suspension at a titre of $4 \log$ TCID $_{50}$, the SD sample was spiked with $2.5 \mathrm{ml}$ of a $10^{3}$ dilution of the virus suspension, and 2.5 $\mathrm{ml}$ of Triladyl ${ }^{\circledR}$ extender (Minitube, Tiefenbach, Germany) was added to the $\mathrm{C}$ sample to equalize the volumes. The trilady ${ }^{\circledR}$ extender consisted of $20 \%(\mathrm{v} / \mathrm{v})$ Trilady ${ }^{\circledR}$ concentrate and $20 \%(\mathrm{v} / \mathrm{v})$ egg yolk, $60 \%(\mathrm{v} / \mathrm{v})$ distilled water and $0.5 \%(\mathrm{v} / \mathrm{v})$ Equex STM paste (Minitube, Tiefenbach, Germany). Aerobic bacterial culture was performed on a representative aliquot of each batch of semen extender.

\subsection{Cryopreservation of semen}

The three semen aliquots were processed individually, making use of separate freezing equipment to prevent cross-contamination. The control sample was processed first. Semen was frozen in $0.25 \mathrm{ml}$ French mini straws as per Standard Operating Procedures of the Section of Reproduction of the Faculty of Veterinary Science, University of Pretoria. Briefly, this involved extending the aliquots to a total of $15 \mathrm{ml}$ with Triladyl ${ }^{\circledR}$ extender; the volume required to deliver straws with at least 20 million progressively motile sperm. Semen and extender was equilibrated at $4{ }^{\circ} \mathrm{C}$ for at least $2 \mathrm{hrs}$, after which the straws were filled and placed on a freezing rack $4 \mathrm{~cm}$ above liquid nitrogen $\left(\mathrm{LN}_{2}\right)$ for $25 \mathrm{~min}$. The straws were then plunged into $\mathrm{LN}_{2}$, packed and stored in $\mathrm{LN}_{2}$ flasks until used.

\subsection{Semen processing methods}

\subsubsection{Swim-up}

The thawed semen sample was overlaid with $2 \mathrm{ml}$ Sperm Tyrode's albumin lactate pyruvate (TALP) medium (Merck, Modderfontein, South Africa) and maintained in an incubator at $39{ }^{\circ} \mathrm{C}$ and an atmosphere of $5.5 \% \mathrm{CO}_{2}$-in-air for $60 \mathrm{~min}$. After a $1 \mathrm{hr}$ incubation, the top layer was aspirated and washed in $2 \mathrm{ml}$ Sperm TALP medium by centrifugation at $150 \mathrm{~g}$ for $10 \mathrm{~min}$. 


\subsubsection{Single-layer centrifugation}

Thawed semen was layered onto $2 \mathrm{ml}$ of the species-specific colloid, Bovipure ${ }^{\circledR}$ (Nidacon Laboratories AB, Göthenburg, Sweden) and centrifuged for 10 min at $150 \mathrm{~g}$. The resulting sperm pellet was re-suspended in TALP medium.

\subsubsection{Percoll gradient}

A volume of $2 \mathrm{ml}$ of $80 \%$ Percoll ${ }^{\circledR}$ solution (Sigma-Aldrich, Kempton Park, South Africa) was placed in a Falcon ${ }^{\circledR}$ tube and $2 \mathrm{ml}$ of a $45 \%$ Percoll ${ }^{\circledR}$ solution was slowly and gently overlaid on it, to form a gradient. The semen straws were thawed in $37^{\circ} \mathrm{C}$ water for $40 \mathrm{~s}$, dried and opened using scissors disinfected in $70 \%$ ethanol, and emptied into an Eppendorf tube. Using a $1000 \mu$ pipette, the semen was gently layered on top of the 2 Percoll ${ }^{\circledR}$ solutions and then centrifuged at $250 \mathrm{~g}$ for $25 \mathrm{~min}$. Thereafter, the supernatant was discarded, and the sperm pellet suspended in $2 \mathrm{ml}$ of sperm-TALP and centrifuged at $135 \mathrm{~g}$ for $25 \mathrm{~min}$. The resultant sperm pellet was re-suspended in $2 \mathrm{ml}$ of sperm-TALP and finally centrifuged at $110 \mathrm{~g}$ for $10 \mathrm{~min}$.

\subsubsection{Percoll gradient with trypsin}

A slight modification was made to the method described by Loskutoff (2005). Briefly, $0.25 \%$ trypsin (Sigma-Aldrich, Kempton Park, South Africa) was added to the intermediate layer of three density gradients $(30 \%, 45 \% \& 80 \%)$ of Percoll ${ }^{\circledR}$. Foetal bovine serum (4\%; Biowest, Celtic Diagnostics, Cape Town, South Africa) was added to the $30 \%$ and $80 \%$ Percoll $^{\circledR}$ solutions to serve as a trypsin inhibitor. The samples were then processed as outlined for Percoll ${ }^{\circledR}$ gradient processing above.

\subsection{Semen evaluation methods}

Sperm motility was assessed immediately after thawing and processing, following the methodology outlined by Nöthling and Dos Santos (2012). A small drop of semen was placed on a $22 \mathrm{~mm} \times 22 \mathrm{~mm}$ glass coverslip, which was then inverted and held horizontally until it touched the glass slide, whereupon it was released and the drop allowed to spread radially between the coverslip and glass slide. No coverslips were examined when evidence of bubbles between the coverslip and glass slide was seen. Using a phase- contrast light microscope (Zeiss AXIO Lab.A1, Zeiss South Africa) at 200x 
magnification, starting at the center field of the coverslip, 10 fields along the equator of the coverslip were evaluated for progressive and aberrant motility and means were calculated. Spermatozoa not moving in a straight line were regarded as aberrantly motile.

To evaluate sperm morphology, a small drop of semen was mixed with Eosin-Nigrosin stain and a semen smear made on a glass slide. A total of 200 spermatozoa were evaluated and assessed for morphological normality using phase-contrast microscopy at $1000 \times$ magnification according to the method described by Barth and Oko (1989). To measure spermatozoa concentration, the semen samples were diluted $(1: 10)$ in $90 \mu \mathrm{l}$ of formaldehyde solution. A drop of the solution was placed in the chamber of a Neubauer haemocytometer. Spermatozoa in 10 of the 25 squares were counted, with each square measuring $0.04 \mathrm{~mm}^{2}$ (volume $=0.004 \mathrm{~mm}^{3}$, with a height of $0.1 \mathrm{~mm}$ ). The results were converted to a concentration in sperm per millilitre by multiplying the number of sperm counted in five squares by $0.5 \times 10^{6}$.

\subsection{PCR analysis}

The PCR analysis was based on the methodology of Lubinga (Lubinga et al., 2013). Samples (200 $\mu \mathrm{l}$ of processed semen) were suspended in a $2 \times$ buffer (containing DTT), and Proteinase K (included in the Qiagen ${ }^{\circledR}$ kit) was added, after which the samples were incubated at $56{ }^{\circ} \mathrm{C}$ overnight. The Qiagen ${ }^{\circledR}$ QIAmp DNA mini kit (Whitehead Scientific, Cape Town, South Africa) was subsequently used according to the manufacturer's instructions to extract the DNA. Real-time PCR was performed as described by Bowden (2008). Briefly, $2.5 \mu \mathrm{l}$ of purified DNA was added to each reaction of a real-time PCR Taqman assay. Primers (Lightcycler Taqman master kit, Roche Diagnostics, Mannheim, Germany) at a concentration of 20 pmol were used. These primers target an 89 bp region within the Capripoxvirus open reading frame 074 which encodes the intracellular mature virion protein P32. Capripoxvirus-specific primers and probes had the following sequences: forward primer- CaPV074F1 5'-AAA ACG GTA TAT GGA ATA GAG TTG GAA3', reverse primer- CaPV074R1 5'-AAA TGA AAC CAA TGG ATG GGA TA-3' and probe CaPV074P1 5' -6FAM-TGG CTC ATA GAT TTC CT-MGBNFQ-3'. The reaction was carried out using a Light $\mathrm{Cycler}^{\circledR}, 2.0$ instrument (Roche Diagnostics, Mannhein, Germany) using the following program: A FastStart Taq Polymerase enzyme activation step of $10 \mathrm{~min}$ at $95{ }^{\circ} \mathrm{C}$. The amplification consisted of 45 cycles of denaturation at $95^{\circ} \mathrm{C}$ for $10 \mathrm{~s}$, 
annealing at $60{ }^{\circ} \mathrm{C}$ for $60 \mathrm{~s}$ and extension at $72{ }^{\circ} \mathrm{C}$ for $1 \mathrm{~s}$ (single acquisition mode). A sample was regarded positive if a Ct value of less than 39 was recorded.

\subsection{Virus isolation}

Virus isolation was performed on LSDV PCR positive semen samples. Dermis (BD) cells of cattle were used and maintained in $5 \mathrm{ml}$ of minimum essential medium (MEM) containing 4\% foetal bovine serum (Biowest, Celtic Diagnostics, Cape Town, South Africa) and $1 \mathrm{ml}$ gentamycin $(0.1 \mathrm{mg} / \mathrm{ml})$. Twenty-4-well plates were prepared containing 480,000 cells $/ \mathrm{ml}$ and incubated at $37^{\circ} \mathrm{C}$ for $24 \mathrm{hrs}$ in an atmosphere of $5 \% \mathrm{CO}_{2}$. Semen samples were inoculated directly onto the cell monolayers. Cell cultures were observed daily for cytopathic effects. After 14 days, negative cultures were frozen briefly at $-70{ }^{\circ} \mathrm{C}$ and then thawed. A second passage was performed and each culture was observed for a further 14 days. A third passage was performed for negative samples. A cell monolayer without any virus was used as negative control while a cell monolayer inoculated with 0.2-0.5 ml LSDV (strain V103/91) suspension at a titre of 4 log TCID 50 was used a positive control.

Table 1 Viral status (PCR and VI) of control, large dose (LD) and small dose (SD) LSDV-spiked frozenthawed semen of a bull following different semen processing methods aimed at removing virus.

\begin{tabular}{lccccccccc}
\hline & \multicolumn{3}{c}{ Virus isolation } & \multicolumn{3}{c}{ PCR } & \multicolumn{3}{c}{ Ct-values } \\
& Control & LD & SD & Control & LD & SD & Control & LD & SD \\
\hline Swim-up & - & + & + & - & + & + & - & 32.90 & $>40.00$ \\
SLC & - & + & + & - & + & + & - & 25.33 & 35.30 \\
Percoll & - & + & + & - & + & + & - & 30.81 & $>40.00$ \\
PT $^{\mathrm{b}}$ & - & + & - & - & + & - & - & 31.78 & - \\
\hline
\end{tabular}

aSLC = single layer centrifugation

bPT $=$ Percoll with trypsin 


\subsection{Electron microscopy}

In preparation for transmission electron microscopy, $100 \mu \mathrm{L}$ of the processed semen samples was mixed with an equal volume of $2.5 \%$ phosphate buffered glutaraldehyde and fixed overnight. Using gentle centrifugation $(1096 \times g$ for $10 \mathrm{~min})$ and resuspension, the samples were washed in Millonig's buffer, $\mathrm{pH} 7.4$ before post-fixation treatment in similarly buffered $1 \%$ osmium tetroxide for $1 \mathrm{hr}$. After two subsequent washes in buffer, the samples were dehydrated through a graded ethanol series (50\%, $70 \%, 80 \%, 90 \%, 96 \%, 100 \%)$. Samples were embedded in epoxy resin, sectioned and stained with lead citrate and uranyl acetate before viewing in a Philips CM10 transmission electron microscope (Philips Electron Optical Division, Eindhoven, The Netherlands) operated at $80 \mathrm{kV}$.

\section{Results}

\subsection{Viral status and sperm quality after processing}

None of the semen processing methods tested were able to clear frozen-thawed semen of LSDV, except for the Percoll gradient with added trypsin (Table 1). The trypsin-Percoll gradient method resulted in failure to amplify LSDV DNA from frozen-thawed semen samples spiked with the smaller dose of LSDV. Virus isolation also failed to demonstrate any LSDV in samples treated this way. The sperm quality variables, however, were reduced markedly by this treatment; progressive motility decreased to $8 \%-9 \%$ and morphological defects increased significantly (Table 2).

\subsection{Electron microscopy}

The LSDV virions, with a size of 200-300 nm and a double-layered envelope, could be detected in the surrounding fluid and associated with the sperm plasma membrane (Figure 1). 


\section{Discussion}

This study demonstrated that common semen processing methods were not able to eliminate LSDV from cryopreserved bull semen, which is analogous to what has previously been described for bovine viral diarrhea virus (BVDV; Bielanski et al., 1992), bovine leukaemia virus (BLV; Bielanski et al., 2000), bovine immunodeficiency virus (BIV; Bielanski et al., 2001) and human papillomavirus (HPV; Niederberger, 2012) in semen. There, however, are examples in the literature of the successful removal of viruses from semen using either swim-up or Percoll ${ }^{\circledR}$ gradient centrifugation. These viruses include equine arteritis virus (EAV; Morrell \& Geraghty, 2006), porcine reproductive and respiratory syndrome virus (PRRSV; Morfeld et al., 2004), human immunodeficiency virus1 (HIV-1) and the hepatitis C (HCV) virus (Loskutoff et al., 2005).

Table 2 Percentages of progressively motile and morphologically normal spermatozoa and sperm concentrations of control, Large dose (LD) and small dose (SD) LSDV-spiked frozen-thawed semen of a bull following different semen processing methods

\begin{tabular}{lcccccccrrr}
\hline & \multicolumn{3}{c}{$\begin{array}{c}\text { Progressive } \\
\text { motility (\%) }\end{array}$} & \multicolumn{3}{c}{$\begin{array}{c}\text { Morphologically } \\
\text { normal (\%) }\end{array}$} & \multicolumn{3}{c}{$\begin{array}{c}\text { Concentration } \\
\left(\times \mathbf{1 0}^{\mathbf{6}} / \mathbf{m l}\right)\end{array}$} \\
& Control & LD & SD & Control & \multicolumn{1}{c}{ D } & SD & Control & \multicolumn{1}{c}{ LD } & SD \\
\hline Post-thaw & 40 & 20 & 28 & 67 & 62 & 69 & 110 & 94.2 & 102.1 \\
Swim-up & 53 & 56 & 34 & 92 & 91 & 90 & 0.5 & 0.5 & 0.4 \\
SLC & 53 & 35 & 36 & 81 & 82 & 78 & 35.1 & 61.5 & 42.1 \\
Percoll & 43 & 39 & 38 & 86 & 87 & 87 & 41.2 & 41.3 & 38.8 \\
PT & 8 & 9 & 9 & 68 & 70 & 64 & 31.1 & 29.6 & 28.7 \\
\hline
\end{tabular}

$\mathrm{SLC}=$ single layer centrifugation

PT = Percoll with trypsin 


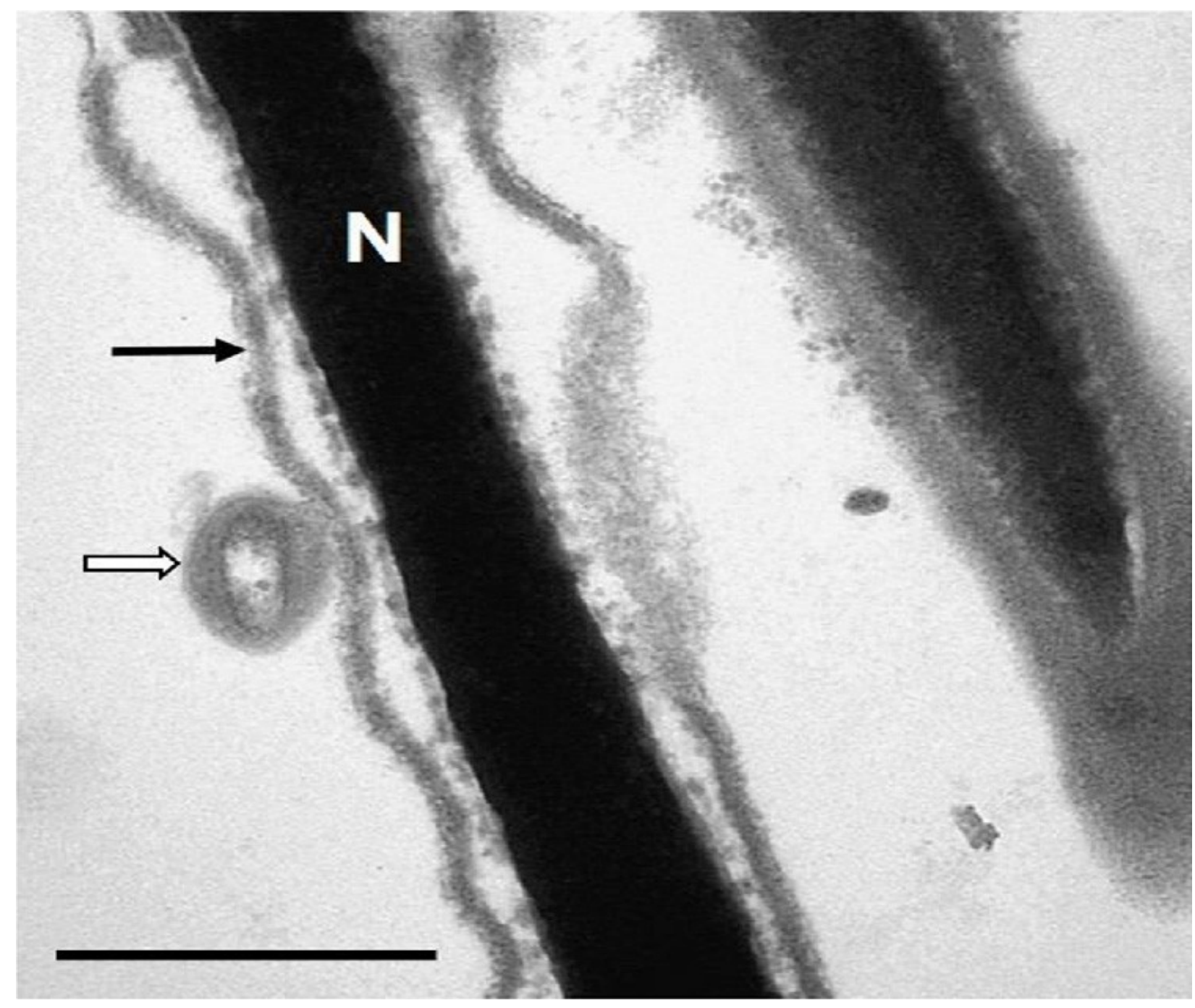

Figure 1 Cross section of a bovine sperm demonstrating the association of an LSDV virion (block arrow) to the sperm plasma membrane (thin arrow)

$\mathrm{N}=$ sperm nucleus

Bar $=0.5 \mu \mathrm{m}$

Da Silva (1999) documented the removal of bovine herpesvirus-1 (BHV-1) from experimentally infected semen using $0.25 \%$ trypsin, but also demonstrated a reduction in the percentage of motile spermatozoa, and increased incidence of sperm membrane damage at a trypsin concentration of $0.3 \%$. In the current study, adding $0.25 \%$ trypsin to the middle layer of a Percoll ${ }^{\circledR}$ gradient prior to centrifugation also succeeded in eliminating the LSDV that resulted from spiking with the smaller dose from frozen-thawed semen samples, but there were similar deleterious effects on sperm motility and membrane integrity, which precludes the use of $0.25 \%$ trypsin to sanitize semen from LSDV positive bulls. Trypsin, as a proteolytic enzyme, has a disrupting effect on BHV-1, a very labile enveloped virus with structural elements that include an icosahedral capsid, 
a tegument and covalently-linked components (Rechenchoski et al., 2017). In contrast, the poxvirus mature virions, responsible for viral transmission between hosts, have a more complex structure including an additional outer membrane, making them very stable and resistant to decontamination processes (Tulman et al., 2001; Moss, 2006).

This study further documented the association of LSDV with the sperm plasma membrane in a processed semen sample. In a review, Moss (2016) described the attachment of poxviruses to at least four different proteins that bind to chondroitin, heparan and laminin, and ascribed viral entry and membrane fusion to a complex of 11 proteins, of which at least eight must be present. This is in contrast to entry mechanisms of other viruses which normally involve only one to three proteins. The method by which LSDV, as a poxvirus, associates with cells may, therefore, involve a strong binding process and make dislodging and removal of the virus from cells, sperm in this case, very difficult.

It is unknown whether the concentrations of LSDV used in the current study are comparable to those found in bulls naturally infected with LSDV and shedding virus into their semen. The Ct-values for PCR amplification of LSDV DNA in this trial, however, are comparable to those described by Babiuk (2008b) for LSDV in other bodily secretions, all of which were close to the detection limit of the assay. That the semen was spiked with LSDV also raises the question of whether virus added to semen in this way behaves differently to LSDV entering semen following natural infection (Bielanski, 2007). The difficulty in sourcing LSDV-infected semen from naturally infected bulls, especially given the unpredictability of infection and viral shedding into semen, however, complicates implementation of an alternative experimental design. Furthermore, the use of spiked semen induces disease in experimentally inseminated heifers, suggesting that the infectious nature of virus added to semen experimentally is similar to that of virus entering by natural infection (Annandale et al., 2014). In the present study, there was not evaluation of the more advanced techniques of removing pathogens from the semen, which may be more successful. Such techniques include immuno-extenders such as hyper-immune yolk produced for BHV-1 (Silva et al., 2000) and acidification of the semen, which has been described for removal of foot- and-mouth disease virus (Bachrach et al., 1957). Entry of poxviruses into cells is dependent on low pH (Moss, 2016) and it, therefore, is assumed that acidification of semen will not help to free it of LSDV. The 
effect of alkalinisation of semen and the use of hyper-immune yolk extenders to biosanitize semen from LSDV warrant further investigation. The small number of samples evaluated in this study precludes statistical inference, and because semen used was from a single bull a bull effect cannot be excluded. Further research, focused on the promising Percoll and trypsin method, would be indicated to exclude the possibility of an individual bull effect.

In conclusion, the present study documents that common semen processing methods are not effective in rendering semen spiked with LSDV free of the virus. It highlights the ability of trypsin to reduce the LSDV viral load in semen but, unfortunately, at the expense of significant semen quality deterioration. Furthermore, assessments in the present study indicated that there is an ultra- structural association of LSDV with the sperm plasma membrane.

\section{Conflicts of interest}

The authors declare no conflict of interest regarding the submitted manuscript: "Effect of semen processing methods on lumpy skin disease virus status in cryopreserved bovine semen".

\section{Funding}

The study was supported by a grant from the Health and Welfare Sector Education and Training Authority (HWSETA), Department: Higher Education and Training, South Africa. 


\section{References}

Abutarbush S M, Ababneh M M, Al Zoubi I G, Al Sheyab O M, Al Zoubi M G, Alekish M O, Al Gharabat R J. 2015. Lumpy skin disease in Jordan: disease emergence, clinical signs, complications and preliminary-associated economic losses. Transboundary and Emerging Diseases. 62, 549-554.

Al-Salihi K A, Hassan I Q. 2015. Lumpy skin disease in Iraq: study of the disease emergence. Transboundary and Emerging Diseases. 62, 457-462.

Annandale C H, Holm D E, Ebersohn K, Venter E H. 2014. Seminal transmission of lumpy skin disease virus in heifers. Transboundary and Emerging Diseases. 61, 443-448.

Annandale C H, Irons P C, Bagla V P, Osuagwuh U I, Venter E H. 2010. Sites of persistence of lumpy skin disease virus in the genital tract of experimentally infected bulls. Reproduction in Domestic Animals. 45, 250-255.

Babiuk S, Bowden T R, Boyle D B, Wallace D B, Kitching R P. 2008a. Capripoxviruses: an emerging worldwide threat to sheep, goats and cattle. Transboundary and Emerging diseases. 55, 263-272.

Babiuk S, Bowden T R, Parkyn G, Dalman B, Manning L, Neufeld J, Embury-Hyatt C, Copps J, Boyle D B. 2008b. Quantification of lumpy skin disease virus following experimental infection in cattle. Transboundary and Emerging Diseases. 55, 299-307.

Bachrach H L, Breese Jr. S S, Callis J J, Hess W R, Patty R E. 1957. Inactivation of foot-andmouth disease virus by $\mathrm{pH}$ and temperature changes and by formaldehyde. Proceedings of the Society of Experimental Biology and Medicine. 95, 147-152.

Barth A D, Oko R J. 1989. Abnormal Morphology of Bovine Spermatozoa. Iowa University Press.

Beard P M. 2016. Lumpy skin disease: a direct threat to Europe. Veterinary Record. 178, 557558.

Bielanski A. 2007. Disinfection procedures for controlling microorganisms in the semen and embryos of humans and farm animals. Theriogenology. 68, 1-22.

Bielanski A, Dubuc C, Hare W C D. 1992. Failure to remove Bovine Diarrhea Virus (BVDV) from bull semen by swim up and other separatory sperm techniques associated with in vitro fertilization. Reproduction in Domestic Animals. 27, 303-306.

Bielanski A, Maxwell P, Simard C. 2000. Effect of bovine leukaemia virus on embryonic development and association with in vitro fertilised embryos. Veterinary Record. 146, 255256.

Bielanski A, Nadin-Davis S, Simard C, Maxwell P, Algire J. 2001. Experimental collection and transfer of embryos from bovine immunodeficiency virus (BIV) infected cattle. Theriogenology. 55, 641-648.

Bowden T R, Babiuk S L, Parkyn G R, Copps J S, Boyle D B. 2008. Capripoxvirus tissue tropism and shedding: a quantitative study in experimentally infected sheep and goats. Virology. 371, 380-393. 
Brenner J, Bellaiche M, Gross E, Elad D, Ovd Z, Haimovitz M, Wasserman A, Friedgut O, Stram Y, Bumbarov V, Yadin H. 2009. Appearance of skin lesions in cattle populations vaccinated against lumpy skin disease: statutory challenge. Vaccine. 27, 1500-1503.

Carn V M, Kitching R P. 1995. An investigation of possible routes of transmission of lumpy skin disease virus (Neethling). Epidemiology and Infection. 114, 219-226.

Chihota C M, Rennie L F, Kitching R P, Mellor P S. 2001. Mechanical transmission of lumpy skin disease virus by Aedes aegypti (Diptera: Culicidae). Epidemiology and Infection. 126, 317-321.

Coetzer J A W. 2004. Lumpy skin disease. In: Coetzer J A W, Tustin R C (Eds.), Infectious Diseases of Livestock, Vol. 2. Oxford University Press, Cape Town, South Africa. 12681276.

Irons P C, Tuppurainen E S M, Venter E H. 2005. Excretion of lumpy skin disease virus in bull semen. Theriogenology. 63, 1290-1297.

Loskutoff N M, Huyser C, Singh R, Walker D L, Thornhill A R, Morris L, Webber L. 2005. Use of a novel washing method combining multiple density gradients and trypsin for removing human immunodeficiency virus-1 and hepatitis $C$ virus from semen. Fertility and Sterility. $84,1001-1010$.

Lubinga J C, Tuppurainen E S M, Stoltsz W H, Ebersohn K, Coetzer J A W, Venter E H. 2013. Detection of lumpy skin disease virus in saliva of ticks fed on lumpy skin disease virusinfected cattle. Experimental and Applied Acarology. 61, 129-138.

Morfeld K A, White B, Mills G, Krisher R, Mellencamp M A, Loskutoff N M. 2004. 186 A novel method for eliminating porcine reproductive and respiratory syndrome virus from boar semen and its effects on embryo development. Reproduction, Fertility and Development. $17,243$.

Morrell J M, Geraghty R M. 2006. Effective removal of equine arteritis virus from stallion semen. Equine Veterinary Journal. 38, 224-229.

Moss B. 2006. Poxvirus entry and membrane fusion. Virology. 344, 48-54.

Moss B. 2016. Membrane fusion during poxvirus entry. Seminars in Cell and Developmental Biology. 60, 89-96.

Niederberger C. 2012. Re: semen washing procedures do not eliminate human papilloma virus sperm infection in infertile patients. Journal of Urology. 187, 1793-1794.

Nöthling J O, Dos Santos I P. 2012. Which fields under a coverslip should one assess to estimate sperm motility? Theriogenology. 77, 1686-1697.

OIE. 2006. Lumpy Skin Disease in Egypt. Disease Information, Office International des Epizooties.https://www.oie.int/wahis 2/public/wahid.php/Reviewreport/Review?page refer=M apEventSummary\&reportid $=5228$

OIE. 2010. Manual of Diagnostic Tests and Vaccines for Terrestrial animals. Chapter 2.4.14, Lumpy Skin Disease, Paris.

Rechenchoski D Z, Faccin-Galhardi L C, Linhares R E C, Nozawa C. 2017. Herpesvirus: an underestimated virus. Folia Microbiologica. 62, 151-156. 
Rouby S, Aboulsoud E. 2016. Evidence of intrauterine transmission of lumpy skin disease virus. Veterinary Journal. 209, 193-195.

Silva N, Solana A, Castro J M. 1999. Evaluation of the effects of different trypsin treatments on semen quality after BHV-1 inactivation, and a comparison of the results before and after freezing, assessed by a computer image analyzer. Animal Reproduction Science. 54, 227235.

Silva N, Solana A, Castro J M. 2000. Inactivation of bovine herpesvirus 1 in semen using a hyperimmune egg yolk semen extender. Journal of Veterinary Medicine Series B. 47, 6975.

Tasioudi K E, Antoniou S E, Iliadou P, Sachpatzidis A, Plevraki E, Agianniotaki E I, Fouki C, Mangana-Vougiouka O, Chondrokouki E, Dile C. 2016. Emergence of lumpy skin disease in Greece, 2015. Transboundary and Emerging Diseases. 63, 260-265.

Tulman E R, Afonso C L, Lu Z, Zsak L, Kutish G F, Rock D L. 2001. Genome of lumpy skin disease virus. Journal of Virology. 75, 7122-7130.

Tuppurainen E, Oura C. 2014. Lumpy skin disease: an African cattle disease getting closer to the EU. Veterinary Record. 175, 300-301.

Tuppurainen E S M, Lubinga J C, Stoltsz W H, Troskie M, Carpenter S T, Coetzer J A W, Venter E H, Oura C A L. 2013. Mechanical transmission of lumpy skin disease virus by Rhipicephalus appendiculatus male ticks. Epidemiology and Infections. 141, 425-430.

Tuppurainen E S M, Venter E H, Shisler J L, Gari G, Mekonnen G A, Juleff N, Lyons N A, De Clercq K, Upton C, Bowden T R, Babiuk S, Babiuk L A. 2017. Review: Capripoxvirus diseases: current status and opportunities for control. Transboundary and Emerging Diseases. 64, 729-745.

Zeynalova S, Asadov K, Guliyev F, Vatani M, Aliyev V. 2016. Epizootology and molecular diagnosis of lumpy skin disease among livestock in Azerbaijan. Frontiers in Microbiology. 7, 1022. 
6 


\section{Chapter 6}

\section{Absence of lumpy skin disease virus in semen of vaccinated bulls following vaccination and subsequent experimental infection}

\section{U I Osuagwuha, V Baglab, E H Venter ${ }^{b}$, C H Annandalea, P C Irons ${ }^{a}{ }^{\text {, }}$}

asection of Reproduction, Department of Production Animal Studies, Faculty of Veterinary Science, University of Pretoria, Onderstepoort 0110, South Africa

bepartment of Veterinary Tropical Disease, Faculty of Veterinary Science, University of Pretoria, Onderstepoort 0110, South Africa

\section{Correspondence}

P C Irons: Tel.: +27 12529 8019; Fax: +27 12529 8314; Email: pete.irons@up.ac.za 


\section{Abstract}

Twelve serologically negative bulls were used, six were vaccinated with a modified live LSD vaccine and six unvaccinated. All were then experimentally infected with a virulent field strain of LSDV. No clinical abnormality was detected following vaccination, and mild clinical signs were seen in four vaccinated bulls following challenge. Virus was not found in semen of vaccinated bulls. Two of the unvaccinated bulls developed severe LSD and four showed mild symptoms, all excreted the virus in the semen following challenge. This study confirmed the ability of LSD vaccination to prevent the excretion of LSDV in semen of vaccinated bulls.

(c) 2006 Elsevier Ltd. All rights reserved.

\section{Keywords}

Lumpy skin disease virus; Neethling strain vaccine; Semen 


\section{Introduction}

The widespread use of artificial insemination in cattle production has facilitated the exchange of genetic material at the national and international level and assisted with the control of sexually transmitted diseases.

Lumpy skin disease (LSD) is caused by a virus in the genus Capripoxvirus of the family Poxviridae. It is an acute, subacute or inapparent disease in cattle and affects all ages and breeds $[8,15]$. The disease is characterized by pyrexia, generalized skin and internal pox lesions which can be seen as firm eruptions of circumscribed nodules in the skin, and generalised lymphadenopathy $[8,15,19]$. The disease causes significant economic loss due to hide damage, loss of milk production, mastitis, infertility and death [26]. The morbidity rate in natural occurrence varies from $3 \%-85 \%$. About $40 \%-50 \%$ of experimentally infected animals exhibit the clinical signs, and mortality is usually less than $3 \%[2]$.

Lumpy skin disease is primarily transmitted by biting insects, particularly blood feeding insects, such as the mosquito [5]. Contact transmission between animals may occur at low rate but cannot be considered to play a significant role in transmission during epizootics $[2,5]$. Lumpy skin disease virus is excreted in the semen of susceptible bulls following experimental infection $[14,26]$. This is a potential risk in the movement of semen from countries where LSD occurs to countries free of the disease, although there is no evidence to suggest transmission via infected semen.

The disease was considered a "List A" disease by the Office International des Epizooties (OIE) due to its potential for rapid spread and ability to cause severe economic losses [18]. It is a constraint in international trade of live animals and their products.

The most widely used and viable means of controlling the disease in endemic countries is by vaccination [12]. The Neethling strain of LSDV, which is a live strain of Capripoxvirus, has been used successfully in a vaccine for the control of LSD in southern Africa $[12,26]$. This vaccine is developed by attenuation of a field isolate in tissue culture and on the chorioallantoic membranes of embryonated hens's egg [26]. According to the manufacturers, immunity to LSD starts developing 10 days after vaccination and reaches 
its peak after 21 days. However, the vaccine does not necessarily confer absolute immunity to all animals vaccinated [12].

Although immunity to LSD is mainly cell-mediated, the production of antibodies is a useful indicator of the response to vaccination $[12,16,26]$. However, literature has shown the absence of detectable levels of antibodies after vaccination in some animals which were nevertheless immune to LSD when challenged [26].

The possibility of the vaccine virus being excreted in the semen following vaccination cannot be ruled out due to the fact that the vaccine virus replicates in the body of the animal. Shedding of vaccine virus in semen has been reported using a live attenuated PRRS-vaccine in boars [23].

The first objective of this study was to determine whether LSD vaccine virus is excreted in semen following vaccination with the modified live vaccine. The second objective was to determine the efficacy of vaccination in preventing LSDV excretion in semen of experimentally infected vaccinated bulls. Furthermore, the study aims at incorporating vaccination into biosecurity protocols for the export of bull semen from infected countries.

\section{Materials and methods}

\subsection{Animals and housing}

Twelve unvaccinated postpubertal Dexter bulls were acquired from herds where vaccination against lumpy skin disease is not practiced. All bulls were tested to be seronegative using the serum virus neutralizing test (SNT). They were also tested for their ability to produce semen before purchase, and again before the onset of the experiment. The bulls were housed in groups of three in isolated pens within an insect proof house with concrete floor covered with bedding. The bulls were provided with forage and water ad libitum. All bulls were between 11 and 16 months of age. Ejaculation was induced in all bulls by electrical stimulation. The experimental trial was divided into three periods, i.e. periods of acclimatization, vaccination and challenge. 


\subsection{Vaccine and vaccination procedure}

Six bulls were vaccinated using the attenuated Neethling vaccine (Lumpy skin disease vaccine for Cattle, Onderstepoort Biological Products Ltd., Onderstepoort, Pretoria, Republic of South Africa) after a 2-3 week acclimatization period. The vaccine was reconstituted and a $5 \mathrm{ml}$ dose was administered subcutaneously to each bull according to the manufacturer's instructions. Three weeks after the first vaccination, none of the bulls had detectable antibody titres, causing us to consider the possibility of vaccine failure. The animals were therefore vaccinated again on day 21 with a different batch of vaccine to ensure effective vaccination.

\subsection{Challenge virus and procedure}

Twenty-seven days after the second vaccination, the six vaccinated and six unvaccinated bulls were experimentally infected. The experimental material used for inoculation was a virulent South African field isolate strain V248/93 of LSDV. The virus was prepared by three times passaged culture on bovine dermis cell monolayers, with an infective dose titre of $10^{5} \mathrm{TCID}_{50} / \mathrm{ml}$. All bulls were inoculated intravenously with $2 \mathrm{ml}$ of this virus suspension.

\subsection{Clinical observation}

The bulls were regularly examined throughout the trial. Clinical examination and rectal temperature was done daily during the period of acclimatization and vaccination and twice daily during the period of challenge. Clinical parameters observed and recorded were the general health of the bulls, superficial inguinal lymph nodes, left and right prescapular lymph nodes, rectal temperature, skin lesions and scrotal circumference. A febrile response was defined as a rise in rectal temperature above $39.5^{\circ} \mathrm{C}$.

\subsection{Blood sampling and semen collection}

During the vaccination period, blood samples were collected twice a week and tested using the SNT. In the challenge period, blood samples were collected every other day and tested using virus isolation (VI) and SNT. 
Semen samples were collected by electro-ejaculation twice a week during the vaccination period and every second day during the challenge period. Samples were tested for LSDV using PCR.

All ejaculates were collected into newly graduated sample tubes using collection funnels. Cross-contamination between animals was avoided by using different funnels for each animal for collection of all samples. Between collections, funnels were washed thoroughly with clean water, and rinsed with hot distilled water. Semen samples were frozen at $20^{\circ} \mathrm{C}$ until PCRs were done.

\subsection{Serum neutralization test}

The SNT was done by using a 96-well, flat-bottomed cell culture microtitre plates. The test sera were diluted to $1: 5$ in a minimum essential medium (MEM) containing $5 \%$ foetal calf serum and $0.05 \mathrm{ml}$ gentamycin (stock $50 \mathrm{mg} / \mathrm{ml}$ ) and inactivated at $56^{\circ} \mathrm{C}$ for $30 \mathrm{~min}$. A series of two-fold dilutions of the inactivated test serum was prepared and $100 \mu$ of the serum was added in duplicate to each of the wells. The titre of the LSDV used was determined and $100 \mu \mathrm{l}$ of a 100 TCID $_{50}$ was then added to each of the wells.

As cell control, $200 \mu \mathrm{l}$ of MEM was added to 12 wells. For virus control, three, 10-fold dilutions of antigen (100 TCID 50 ) were made and $100 \mu \mathrm{l}$ of each dilution was added to $100 \mu$ of MEM in each well. The microtitre plate was incubated at $37^{\circ} \mathrm{C}$ for $1 \mathrm{~h}$. Following incubation, $80 \mu$ l of bovine dermis cells at a concentration of 480,000 cells $/ \mathrm{ml}$ were added to all the wells.

The microtitre plates were further incubated at $37^{\circ} \mathrm{C}$ in an incubator containing $5 \% \mathrm{CO}_{2}$. Using an inverted microscope, the monolayers were examined daily for seven days for evidence of cytopathic effect (CPE). The cell control indicated how long the cells remained viable and for how long it was possible to read the test before cell degeneration. The absence of CPE was an indication of neutralization and therefore a positive antibody reaction. 


\subsection{Virus isolation}

Bovine dermis cells at $\pm 50 \%$ confluence grown in $25 \mathrm{~cm}^{2}$ culture flasks were infected with $0.5 \mathrm{ml}$ heparinized blood. After 24 hrs the medium was removed and the cells were washed twice with buffered phosphate saline containing $\mathrm{Mg}^{2+}$ and $\mathrm{Ca}^{2+}(\mathrm{PBS}+)$ containing $0.05 \mathrm{ml}$ gentamycin (stock $50 \mathrm{mg} / \mathrm{ml}$ ). The medium was replaced with MEM containing $5 \%$ foetal calf serum and gentamycin (stock $50 \mathrm{mg} / \mathrm{ml}$ ). The cell cultures were observed daily for CPE. After 14 days, negative cultures were frozen briefly at $-70^{\circ} \mathrm{C}$ and thawed. The flasks were shaken gently to break up the cell material and to release the cell-bound virus. A second passage was done and observed for 14 days. Positive cell cultures were stored at $-70^{\circ} \mathrm{C}$.

\section{$2.8 \quad$ PCR}

The extraction method used was a modification from the method described by Gubbels [11] and Schwartz [21]. The semen samples were tested by the PCR using primers developed from the gene for viral attachment protein [13], and had a forward primer of 5'-d TTTCCTGATITTCTTACTAT 3' and reverse primer: 5'-d AAATTATATACGTAAATAAC $3^{\prime}$. The size of the amplicon was $192 \mathrm{bp}$.

A positive control of bovine semen spiked with LSDV was used; negative semen controls consisting of bovine semen as well as a water control were included in the PCR. Amplified products were analyzed on $1.5 \%$ agarose gels using a 100 bp DNA ladder (Whitehead Scientific Ltd.) as a molecular marker. Amplicons were visualized using an UV transilluminator at a wavelength of $300 \mathrm{~nm}$ and positive amplicons were indicated by the presence of bands corresponding to those of the positive control sample.

\section{Results}

\subsection{Clinical signs}

\subsubsection{Unvaccinated bulls}

Two of the unvaccinated bulls developed severe LSD and four showed mild to inapparent infections. In the severely affected group fever started on days 6 and 7 post-infection (p.i.) and lasted for 12 and 16 days. Multiple skin lesions developed five days later and 
corneal opacity was observed 2-3 weeks after the appearance of skin lesions. These bulls were febrile for nine days and became depressed and inappetant. Symptoms in the other bulls were limited to transient febrile reactions and few skin lesions which did not persist.

\subsubsection{Vaccinated bulls}

No clinical abnormalities were detected following vaccination, and clinical signs were limited to mild lymph node enlargement in four bulls following challenge of the vaccinated bulls.

\subsection{Serum neutralization test}

\subsubsection{Vaccinated bulls}

Three of the vaccinated bulls were serologically positive by day 48 post-vaccination (p.v.) and four bulls by the end of the trial. One animal was found to be serologically negative at the end of the trial having been positive at day 48 p.v. Antibody titres were low following both vaccination and challenge, with maximum titres of $1: 3$ and 1:6, respectively.

\subsection{Viraemia}

\subsubsection{Unvaccinated bulls}

Virus was isolated from heparinized blood samples from both of the severely affected bulls on multiple occasions, in one, seven times during days 9-21 p.i. and in the other eight times on days 9-23 p.i., these being 2 and 1 days after the onset of the fever reaction, respectively, and a day after the appearance of skin lesions. In the mildly affected group, virus was not isolated from one bull but was isolated from the three other bulls on days 15, 17 and 19 p.i., days 11,15 and 25 and from one other bull on day 7 only (Table 1).

\subsubsection{Vaccinated bulls}

None of the vaccinated bulls were found to be viraemic after vaccination or experimental inoculation. 


\subsection{Virus in semen}

\subsubsection{Unvaccinated bulls}

The semen of all bulls except one with an inapparent infection tested positive on one or more occasions using the PCR. The presence of virus in semen is depicted in Table 2. Viral nucleic acid was detected in the severely affected bulls from day 10 p.i. until the end of the trial on day 28 p.i. The onset of the shedding of virus in semen corresponded with the day when the peak of the febrile response was observed.

One semen sample from one of the mildly affected animals tested positive on day $27 \mathrm{p.i}$. and this bull was not found to be viraemic at any stage. The other mildly affected bull tested positive on four occasions between days 12 and 27 p.i. while two other bulls tested positive once each, on days 16 and 18 p.i. (Table 2).

Table 1 Viraemia following experimental infection of unvaccinated bulls, as determined by virus isolation

\begin{tabular}{lccccccccccccc}
\hline Clinical signs & Bulls & \multicolumn{11}{c}{ Days post-infection } \\
\hline \multirow{3}{*}{ Severe } & & $\mathbf{7}$ & $\mathbf{9}$ & $\mathbf{1 1}$ & $\mathbf{1 3}$ & $\mathbf{1 5}$ & $\mathbf{1 7}$ & $\mathbf{1 9}$ & $\mathbf{2 1}$ & $\mathbf{2 3}$ & $\mathbf{2 5}$ & $\mathbf{2 7}$ & $\mathbf{2 9}$ \\
& $\mathrm{D}$ & - & + & + & + & + & + & + & + & - & - & - & - \\
\multirow{3}{*}{ Mild } & $\mathrm{E}$ & - & + & + & + & + & + & + & + & + & - & - & - \\
& $\mathrm{A}$ & - & - & - & - & + & + & + & - & - & - & - & - \\
& $\mathrm{B}$ & - & - & - & - & - & - & - & - & - & - & - & - \\
& C & + & - & - & - & - & - & - & - & - & - & - & - \\
& F & - & - & + & - & + & - & - & - & - & + & - & - \\
\hline
\end{tabular}

$(-)$ Negative for virus isolation; (+) positive for virus isolation 
Table 2 Presence of LSDV in semen following experimental infection, as determined by the PCR

\begin{tabular}{lcccccccccccc}
\hline Clinical signs & Bulls & \multicolumn{10}{c}{ Days post-infection } \\
\hline \multirow{3}{*}{ Severe } & & $\mathbf{1 0}$ & $\mathbf{1 2}$ & $\mathbf{1 4}$ & $\mathbf{1 6}$ & $\mathbf{1 8}$ & $\mathbf{2 2}$ & $\mathbf{2 4}$ & $\mathbf{2 6}$ & $\mathbf{2 7}$ & $\mathbf{2 8}$ \\
& $\mathrm{D}$ & + & + & + & + & + & + & + & + & + & + \\
\multirow{3}{*}{ Mild } & $\mathrm{E}$ & + & + & + & + & + & + & + & + & + & + \\
& $\mathrm{A}$ & - & - & - & - & + & - & - & - & - & - \\
& $\mathrm{B}$ & - & - & - & - & - & - & - & - & + & - \\
& C & - & + & + & - & - & - & + & - & + & - \\
& F & - & - & - & + & - & - & - & - & - & - \\
\hline
\end{tabular}

(-) Negative for PCR; (+) positive for PCR

\subsubsection{Vaccinated bulls}

Viral nucleic acid was not detected in the semen samples of the vaccinated bulls on any day following vaccination or experimental infection.

\section{Discussion}

The duration of viraemia among the unvaccinated bulls varied considerably and was similar to a recent study [25] where virus was isolated within a day of the onset of fever. No vaccinated bulls were found to be viraemic after experimental infection with the same strain of LSDV used in the unvaccinated bulls. It is therefore evident that vaccination did prevent viraemia.

In this study, three of the six vaccinated bulls seroconverted by the end of the vaccination period and four bulls by the end of the trial, with a rise in antibody titre in four bulls. The very low level of antibody formation found in this study is characteristic of the response of $\operatorname{LSDV}[3,16]$. The data suggest that high antibody titres were not necessary to prevent or reduce the manifestation or severity of the clinical signs of the disease in the bulls when experimentally infected. This is thought to be due to the fact that immunity to LSD infection is predominantly cell mediated $[3,17]$. Tuppurainen [25] also demonstrated that the level of antibody titre is proportional with the severity of clinical disease observed in experimentally infected bulls. 
In this study, the failure of any of the six bulls to sero-convert by day 21 p.v. was unexpected as the manufacturer's report indicated that immunity starts developing about 10 days after vaccination and should be fully developed after three weeks [12]. This prompted us to consider the possibility of vaccine failure in this instance, a phenomenon which is well documented $[12,20]$. For this reason, we decided to repeat the vaccination using a different batch of vaccine in an attempt to ensure effective protection, a deviation from our original study design. Whether different results would have been obtained had the vaccination not been repeated cannot be determined.

Previous work by this group indicated that testing for the presence of LSDV in bull semen by PCR is much more sensitive than virus isolation, due largely to the toxicity of bovine semen to tissue cultures $[14,25]$. While centrifugation and serial dilution of samples reduce the toxicity and do allow for observation of cytopathic effects [1], the sensitivity of the test is reduced by these methods. Due to the improbability of identifying additional infected samples using virus isolation and the labour and cost implications of doing virus isolation on large numbers of samples it was decided to use PCR in this study. While it is not possible to infer the presence of infective LSDV in semen from these results, no superior diagnostic method is currently available to achieve this goal. The bioassay used by Givens et al. to demonstrate the presence of infective bovine virus diarrhea virus in semen utilising live susceptible calves [10] was not feasible for this study due to the difficulty in sourcing known susceptible animals and the cost implications of sourcing and housing calves.

In this study, all six experimentally unvaccinated bulls excreted the virus in their semen at one point during the course of the trial. This is in agreement with the observation of Irons [14]. No viral nucleic acid was detected by PCR in the vaccinated group at any point till the trial was terminated. Since the pathogenesis of seminal shedding of LSDV is not known, it is not known how vaccination prevents shedding. The skin nodules which are characteristic of LSD contain a very high concentration of the virus [6]. As nodules often develop within the genital tract in severely affected animals it is possible that LSDV is released from nodules within the genital tract into the semen during passage through the testes or epididymal ducts. However, the fact that there was transient shedding even in bulls that did not develop any clinical signs following challenge suggests that there are 
other mechanisms of voiding of virus in semen.

Shedding of vaccine virus in semen has been shown to occur in boars vaccinated against PRRS [23] but not in boars vaccinated against Pseudorabies [4]. Vaccination was found to reduce seminal shedding of PRRS virus in boars $[22,23]$ and EAV in stallions after challenge $[9,24]$.

A possible explanation for the presence or absence of virus in the semen samples could arise from semen being contaminated with preputial secretions at the time of collection, or cross-contamination between samples from different bulls in subsequent collections. The semen collection technique in the present study was aimed at minimizing contamination of semen samples by trimming the preputial hairs and cleaning with clean water prior to collection. Also, different funnels were used for each animal, and between collections, these funnels were washed thoroughly with clean water and later rinsed with hot distilled water and kept in a rack to dry. Contamination of semen samples with blood during sampling has been implicated in the presence of BLV in semen [7]. No semen samples in the present study apart from samples from two unvaccinated bulls on days 13, 17 and 19 p.i. were visibly contaminated with blood, but the presence of small amounts of blood in other samples cannot be ruled out.

Comparison with results obtained from the experimentally infected vaccinated bulls and those from the non-vaccinated bulls showed that vaccination prevented the excretion of LSDV in the semen of experimentally infected vaccinated bulls. Transient shedding of virus in semen of the vaccinated bulls from days out of the peak periods chosen cannot be excluded but is deemed highly unlikely. Should vaccinated animals experience severe clinical signs following infection as may likely occur [12], the possibility of seminal shedding cannot be ruled out.

The results of this study provide preliminary data on the abilities of the Neethling strain vaccine to prevent seminal shedding of LSDV when challenged. This study supports the inclusion of LSD vaccination with this vaccine as a biosecurity measure when semen is moved from LSD infected areas. It also illustrates further, based on these findings that double vaccination of clinically normal bulls against LSD would prevent the possible 
presence of LSDV in semen collected for export to LSD-free countries during the period immediately following the vaccination. Bulls should nevertheless be monitored for clinical signs of LSD while semen is being collected for export as an additional safeguard.

This study provides the first evidence of the absence of LSDV in bull semen following vaccination. It also illustrates the ability of LSD vaccination to prevent the excretion of LSD viral particles in semen when vaccinated bulls are experimentally infected. 


\section{References}

[1] Bagla V P, Osuagwuh U I, Annandale C H, Irons P C, Venter E H. Elimination of toxicity and enhanced detection of lumpy skin disease virus on cell culture from experimentally infected semen samples. Onderstepoort Journal of Veterinary Research. 2006. 73:263-8.

[2] Barnard B J, Munz E, Dumbell K, Prozesky L. Lumpy skin disease. In: Coetzer J A W, Thomson G R, Tustin R C (Eds.), Infectious diseases of livestock with special reference to Southern Africa, Vol. 1. Oxford University Press, Cape Town, South Africa. 1994. 604-12.

[3] Carn V M. Control of capripox virus infections. Vaccine. 1993. 11, 1275-79.

[4] Castro J M, Del Pozo M, Gil J, Imaz M A, Simarro I, Rillo S M. Effect of a bioengineered pseudorabies (Aujesky's disease) vaccine on the semen quality of boars. Theriogenology. 1992. 38, 165-73.

[5] Chihota C M, Rennie L F, Kitching R P, Mellor P S. Mechanical transmission of lumpy skin disease virus by Aedes aegypti (Diptera: Culicidae). Epidemiology and Infection. 2001. $126,317-21$.

[6] Chihota C M, Rennie L F, Kitching R P, Mellor P S. Attempted mechanical transmission of lumpy skin disease virus by biting insects. Medical and Veterinary Entomology. 2003. 17, 294-301.

[7] Chio K Y, Monke D, Stott J L. Absence of bovine leucosis virus in semen of seropositive bulls. Journal of Veterinary Diagnostic Investigation. 2002. 14, 403-6.

[8] Davies F G. Lumpy skin disease of cattle: a growing problem in Africa and the near east. World Animal Review. 1991. 68, 37-42.

[9] Fukunaga $Y$, Wada R, Matsumura T. An attempt to protect against persistent infection of equine arteritis in the reproductive tract of stallions using formalin inactivated virus vaccine. Equine infectious disease. VI. Newmarket: R\&W Publications Limited. 1991. 239-244.

[10] Givens M D, Heath A M, Brock K V, Brodersen B W, Carson R L, Stringfellow D A. Detection of bovine viral diarrhea virus in semen obtained after inoculation of seronegative postpubertal bulls. American Journal of Veterinary Research. 2003. 64, 428-34.

[11] Gubbels M J, De Vos A P, Van der Weide M, Viseras J, Schouls L M, De Vries E, et al. Simultaneous detection of bovine Theileria and Babesia species by reverse line blot hybridization. Journal of Clinical Microbiology. 1999. 37, 782-9.

[12] Hunter P, Wallace D. Lumpy skin disease in southern Africa. A review of the disease and aspects of control. Journal of the South African Veterinary Association. 2001. 72, 68-71.

[13] Ireland D C, Binepal Y S. Improved detection of capripox virus in biopsy samples by polymerase chain reaction. Journal of Virology Methods. 1998. 74, 1-7.

[14] Irons P C, Tuppurainen E S M, Venter E H. Excretion of lumpy skin disease virus in bull semen. Theriogenology. 2005. 63, 1290-7.

[15] Kitching R P, Taylor W P. Transmission of capripoxviruses. Research in Veterinary Science. 1985. 39, 196-9. 
[16] Kitching R P, Hammond J M. Poxvirus, infection and immunity. In: Roitt I M, Delves P J (Eds.), Encyclopaedia of immunology, Vol. 3, $3^{\text {rd }}$ ed. 1992. 1261-4.

[17] Kitching R P, Carn V. Lumpy skin disease: in manual of diagnostic tests and vaccines for terrestrial animals. 2004.

[18] OIE Manual Bulletin Office International des Epizooties, Paris, France: World Organization for Animal Health 1996.

[19] Prozesky L, Barnard B J H. A study of the pathology of lumpy skin disease in cattle. Onderstepoort Journal of Veterinary Research. 1982. 49, 167-75.

[20] Roth J A. Mechanistic bases for adverse vaccine reaction and vaccine failure. Adv Vet Med 1999. 41, 681-700.

[21] Schwartz I, Varde S, Nadelman R B, Wormser G P, Fish D. Inhibition of efficient polymerase chain reaction amplification of Borrelia burgdorferi DNA in blood fed ticks. American Journal of Tropical Medicine and Hygiene. 1997. 56, 339-42.

[22] Swenson S L, Hill H T, Zimmerman J J, Evans L E, Wills R W, Schwartz K J, et al. Preliminary assessment of an inactivated PRRS virus vaccine on the excretion of virus in semen. Swine Health Production. 1995. 3, 244-7.

[23] Thomas L N, Jens N, Have P, Poul B, Hoff-Jorgensen R, Botner A. Examination of virus shedding in semen from vaccinated previously infected boars after experimental challenge with porcine reproductive and respiratory syndrome virus. Veterinary Microbiology. 1997. 54, 101-12.

[24] Timoney P J. Equine viral artertis: How serious is the threat to British horse population? British Veterinary Journal. 1992. 148, 177-80.

[25] Tuppurainen E S M, Venter E H, Coetzer J A W. The detection of lumpy skin disease virus in samples of experimentally infected cattle using different diagnostic techniques. Onderstepoort Journal of Veterinary Research. 2005. 72, 153-64.

[26] Weiss K E. Lumpy skin disease virus. Virology Monograph. 1968. 3, 111-31. 
7 


\section{Chapter 7}

Summarising discussion 


\subsection{Importance of LSD in cattle health, reproduction and trade}

Despite having been identified several decades ago as a significant pathogen affecting cattle health and production within Sub-Saharan Africa, Lumpy skin disease only really caught the attention of a wider veterinary audience during the second decade of the 21st century. This heightened awareness was triggered by the rapid spread of the disease across the Mediterranean to Turkey, Greece, several Balkan countries and Russia during this period [1]. LSDV was therefore recognised as a major threat to the European Union, and several control measures were put in place to prevent its spread and to protect against the potential effects on cattle health and trade $[2,3]$.

This thesis set out to identify sites of persistence of LSDV in the genital tract of experimentally infected bulls and to quantify the risk posed by the use of LSDV-infected semen. Further questions arose during the execution of the initial experiments, and this guided subsequent investigations. The rapid spread of LSD through North Africa, the Mediterranean, Balkan countries and the European Union, further influenced the development of the latter chapters of the thesis. Given the evolution of the thesis from a focus on the bull as the source of LSDV, to the potential for transmission through an IVEP system, one has to consider that the findings would have different implications for different farming systems. Since South Africa is characterised by diverse farming systems that range from subsistence to technology-rich commercial farming, with a developing cohort of emerging farmers, the thesis is composed in such a way that different aspects relevant to each of these farming systems is addressed.

\subsubsection{Subsistence and emerging cattle farming systems}

The socio-economic effects of LSDV infection in subsistence and emerging cattle farming systems is often not appreciated and remains poorly defined. In this situation, the major impact is via reduced production, which is mediated through the effects of the virus on live weight gain, poor quality hides, poor milk production and smaller calf crops, with the calves growing at a slower rate. Since bulls are limited in numbers within these farming systems, orchitis and prolonged seminal virus shedding following LSDV infection can 
severely affect genetics and income, and the common practice of allowing even severely affected bulls to recover and mate again has important epidemiological implications. Indeed, allowing recovery and re-use of severely affected bulls, would be expected to result in an increased cow return rate (i.e. reduced fertility) and smaller calf crops spread through the year. Such a calving pattern has several disadvantages from a production point of view, since the seasonal rain pattern in South Africa influences grass yield and quality, and calves born at times when grass quality is poor never recover from their initial slow growth rate. The initial poor growth rate can be ameliorated by supplemental feeding, but this is not a viable option within resource-constrained communities.

Chapter 2 therefore presents an experimental study designed to examine the distribution of LSDV in fractions of the ejaculate, and the development of lesions within the genital tracts of bulls. This provided a background to better understand the nature of prolonged shedding of LSDV in bull semen, and the implications thereof, primarily for subsistence and emerging farmers. At this stage, it was not known whether LSDV in semen was associated with a specific fraction of the ejaculate or with red blood cells, and the mechanisms underlying reported shedding of viral DNA in semen for up to 159 days, had not been studied. The study showed that virus and viral DNA were shed in all fractions of the ejaculate, and shedding was not associated with the presence of blood in the ejaculate; moreover, in bulls showing severe clinical disease, necrotic foci developed in the testes and epididymides as a result of the viral pathogenesis [4]. Immunoperoxidase staining showed viral association with the necrotic foci, suggesting that the prolonged seminal shedding occurred as a result of voiding of viral DNA from necrotic areas into patent seminiferous tubules and the vas deferens. Interestingly, as suggested by Irons [5], all bulls infected with LSDV, irrespective of the severity of clinical signs exhibited, shed the virus and viral DNA into their semen at some point. The epidemiological significance of this finding is currently not known, but it suggests that all bulls exposed to the virus during an outbreak, even those that do not exhibit clinical signs, may serve as a source of virus to insect vectors and aid further spread of the disease within a population.

Histopathological examination of the affected testes showed severe and extensive necrosis, resulting in numerous empty seminiferous tubules and obliteration of the 
epididymal ducts. It is currently not known if a bull can recover from such extensive testicular damage, but field reports seem to indicate that recovery does occur in some individuals, although reduced daily sperm production is likely. It is possible that bulls that show protracted seminal shedding of LSDV can help to maintain virus in interepidemic periods, although this is difficult to confirm given the paucity of data regarding duration of persistence of the necrotic areas in the testes and epididymides. Since bulls have been shown to be febrile for up to 3 weeks [6] and the recovery period is lengthy, the direct effect of severe lumpy skin disease in subsistence farming, and in single-sire systems, will take the form of failure to mate or conceive, and can be economically devastating.

Chapter 3 presents an investigation of the consequences of insemination with LSDVcontaminated semen. The use of LSDV-spiked semen resulted in clinical LSD in some of the heifers, confirming seminal transmission of LSDV for the first time [7]. Either due to the resulting viraemia, or a direct virus effect, the pregnancy rate in the study was low, suggesting that low pregnancy rates would be observed in subsistence and emerging cattle farming systems in the face of an outbreak of LSDV. Extensive necrosis of the entire female reproductive tract (excluding the ovaries) was observed in cows displaying severe clinical LSD. It is unlikely that these cows would recover sufficiently to subsequently conceive or carry a calf to term. In mildly-affected animals, the extent of damage to the udder may also preclude their ability to raise calves at foot and consequently lead to lowered production. These findings further underline the financial losses that can be expected during an LSD outbreak.

\subsubsection{Commercial farming systems}

The effects of LSDV are not restricted to subsistence and emerging cattle farming systems, but assume a different form in more highly developed, commercial farming systems. In these systems, more focus is placed on production efficiency, assisted reproductive technologies are used and trade extends to frozen semen and embryos, in addition to hides, milk and meat. Commercial farmers are therefore primarily affected by trade restrictions and, since Lumpy skin disease is an OIE-listed disease, it is relevant within this setting to consider the health and reproductive effects of lumpy skin disease. 
The need to address gaps in our knowledge of the epidemiology of Lumpy skin disease is therefore of equal importance, regardless of the farming system involved.

As a chapter addressing questions relevant to both farming systems, Chapter 3 showed that embryos were infected with the virus, but that these in vivo-produced embryos could be washed free of the virus by following the IETS washing protocol guidelines. In heifers not used for embryo flushing, severe clinical signs were observed in the caudal reproductive tracts, suggesting that the embryo flushing media had a local protective effect on the reproductive tracts of the embryo donor heifers. This study therefore showed that some risk is associated with trade in germplasm from countries where LSD is endemic, thereby supporting the current OIE-regulations. The OIE requires strict vaccination and testing of quarantined animals, as well as their germplasm, before allowing trade from LSDV-infected countries [8].

Further support for the current OIE-regulations was produced by Chapters 4 and 5 of this thesis. Investigating the effect of using frozen-thawed semen contaminated with LSDV for in vitro embryo production (IVEP), revealed that virus could be detected in fertilization media and all embryonic structures when high virus doses were present in the frozenthawed semen [9]. LSDV virions were detected inside hatched and unhatched Day 8 blastocysts by transmission electron microscopy. Common semen processing methods were not able to remove LSDV from cryopreserved semen, with the exception of the addition of trypsin to a Percoll $\circledast$ gradient; however, the success of this latter treatment was at the expense of semen quality and only reduced, but did not eliminate, viral load [10]. Moreover, it was shown that LSDV virions ultrastructurally associate with the sperm membranes. The findings of Chapters 4 and 5 therefore provide concrete evidence of the risk of LSDV to international trade in frozen-thawed semen, both in vivo and when embryos are produced in vitro. 


\subsection{The effect of LSDV viral dose}

Following the conclusion of Chapter 3, questions arose regarding the effect of the LSDV viral dose used in these studies. Whereas a high viral dose might have been necessary to ensure that disease was produced, and therefore facilitates the experimental study of disease progression and its effects, it also may not accurately reflect the natural infection dynamics. The experimental design of both Chapters 4 and 5 therefore included a high dose, consisting of $4 \log$ TCID $_{50}$ of an LSDV isolate, and a lower dose of a $10^{3}$ dilution of the high dose.

Chapter 4 studied the use of frozen-thawed semen contaminated with LSDV on IVEP and aimed to highlight the effect of virus load on the success of embryo production. It further investigated the biosecurity risk associated with LSDV within IVEP, bearing in mind that embryos are an important part of the international trade in bovine genetics. The IVEP results for oocytes exposed to frozen-thawed semen contaminated with low doses (LD) of LSDV were characterized by lower cleavage and blastocyst production rates, even though virus or viral DNA could not be detected in any of the samples [9]. When frozenthawed semen with a higher virus dose (HD) was used, fertilization media and embryonic structures tested positive by PCR and virus isolation, providing evidence for a viral doserelated effect of LSDV within an IVEP system. The absence of viral DNA in samples from the LD group was attributed to a lower Ct value in frozen-thawed semen samples, and reduction of the viral load by semen processing and oocyte denudation to below the detection limit of the PCR assay.

A clear difference was observed between semen processing of samples exposed to a high dose of LSDV and those exposed to a low dose of LSDV [10]. Some semen processing methods were successful at reducing viral load to below the detection limit of the PCR assay for the lower viral dose samples, but not for the higher dose samples. This suggests that the viral load at the start of semen processing was the major determinant of whether the semen processing method is likely to successfully clear the semen sample of LSDV. More advanced semen processing methods may hold promise with regards to bio-sanitation of LSDV-infected semen, but this remains to be investigated [12]. High 
costs and reduced sperm quality may preclude their utility as routine methods for semen processing at AI centres.

It is therefore clear that LSDV viral load does influence the reproductive effects of the virus and attempts to ameliorate the risk associated with the use and trade of bovine semen and embryos. Given that the Ct-values for PCR amplification in these studies were similar to the reported values for other bodily secretions [11], and therefore to levels that can be expected with a natural outbreak, the biosafety of the use of semen contaminated with LSDV and within IVEP remains questionable and does therefore not warrant a reevaluation of the existing OIE-regulations.

\subsection{Clinical syndromes associated with LSDV infection}

Over the course of three different experiments [4, 5, 7], totalling 31 cattle and employing similar materials and methods, clear clinical syndromes were identified. These syndromes are illustrated in Figure 7.1 below.

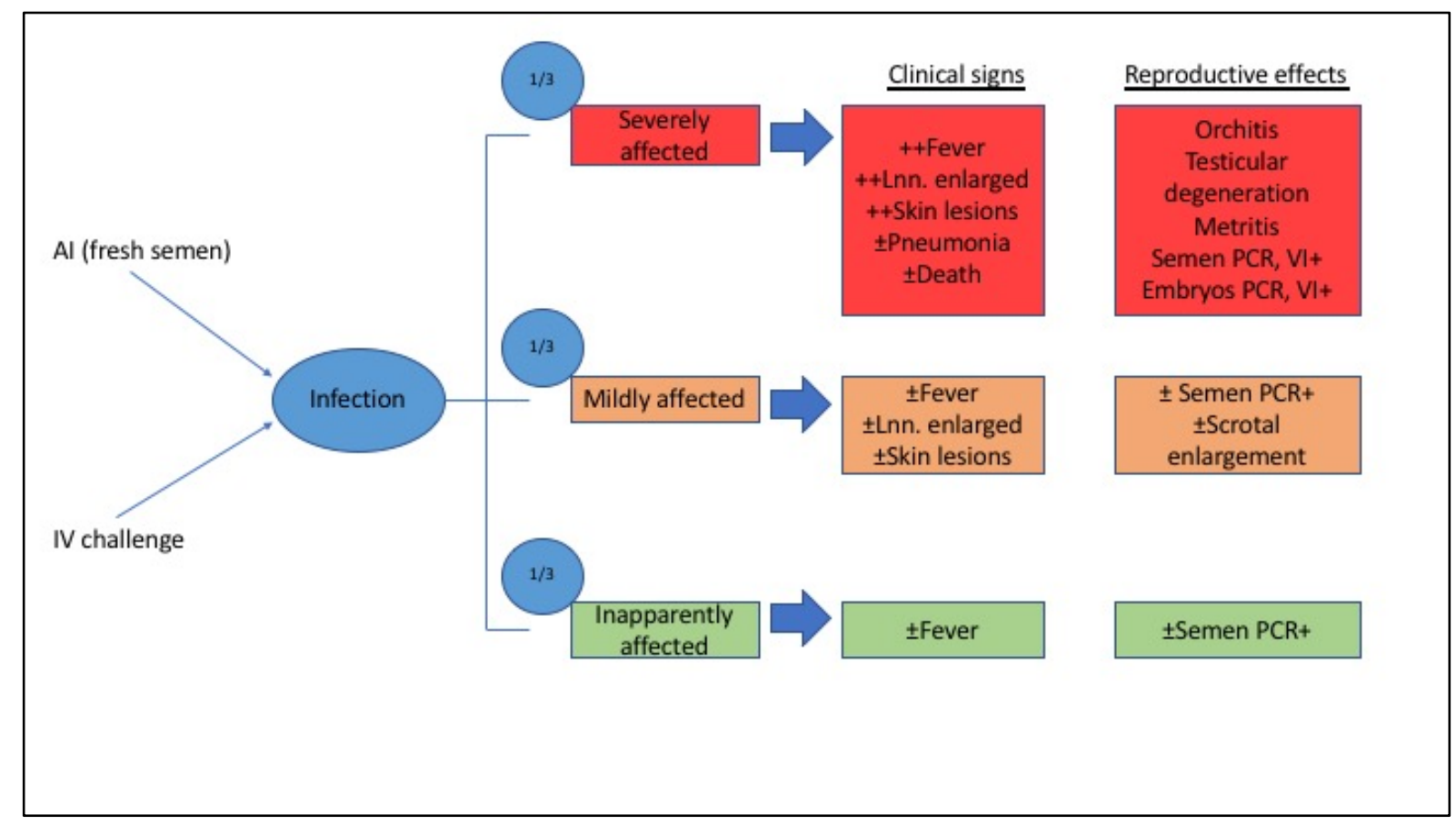

Figure 7.1: Clinical syndromes associated with LSDV infection

Under experimental conditions, employing artificial insemination with fresh semen or intravenous (IV) challenge with field strain LSDV, the clinical syndromes were evenly 
spread among the cattle. Cattle could be classified as falling into one of three clinical syndromes:

7.3.1 Severely affected LSD: These animals displayed inappetence and severe fever (sometimes in excess of $40.5^{\circ} \mathrm{C}$ ) lasting for a couple of weeks, generalised lymphadenopathy characterised by prescapular lymph nodes swelling to greater than 5 $\mathrm{cm}$ in diameter, widespread skin nodules displaying areas of sloughing and necrosis, and occasional pneumonia and death. From a reproductive perspective, viable virus and viral DNA could be identified in both embryos and semen, the latter for a long period of time. The genital tracts of affected animals showed clear clinical signs ranging from testicular degeneration and accompanying reduced scrotal circumference, to necrotic metritis, cervicitis and mastitis.

7.3.2 Mildly affected LSD: Animals that fell into this category displayed low-grade fever lasting a couple of days and superficial lymphadenopathy. Lymph nodes never enlarged to beyond $5 \mathrm{~cm}$ and only a few skin nodules were observed, mostly over the scapular area and on the lower flanks. Viral DNA could be identified in some semen samples, and bulls typically showed scrotal enlargement but returned to normal within about a week. As opposed to semen collection, which can be performed repeatedly over a long experimental period, embryos were flushed on day 6 or 7 after AI, and therefore it is not known whether embryos could become infected with LSDV at a later stage post-infection in this category of LSD-infected animals.

7.3.3 Inapparently affected LSD: This category of animals only displayed fever on one or two days, and showed no other clinical signs. Viral DNA could be identified in semen samples on very few (one or two) occasions only.

From the results of Chapter 4 and 5 it seems that the virus load at the time of infection may play a role in determining which clinical syndrome category LSDV-infected cattle may fall into. This would support the earlier findings of Carn and Kitching [13]. 


\subsection{Limitations and future research areas}

This thesis is composed of a series of experimental studies, and while they provided an insight into reproductive aspects of LSD and the risks associated with trade in germplasm in situations when LSDV is circulating, the validity of our findings has yet to be confirmed under field conditions. Future studies should aim to use field LSD outbreak material optimally; areas of specific focus should be the virus load associated with seminal shedding, follow-up of bulls that display severe LSD to establish the period required for, and the degree of, recovery and the success of semen bio-sanitation methods applied to semen collected from naturally infected bulls.

The routes of challenge used in our studies were intravenous inoculation and artificial insemination. Future studies should seek to establish whether infection via intradermal inoculation, as is the case for transmission via biting insects, leads to similar findings. Given the longer period of exposure during intradermal inoculation, and the different route of migration to the bloodstream and lymph nodes, it is conceivable that different immunological pathways may be involved in protection and response to different routes of infection. This warrants investigation, because it may impact the extent to which semen shedding of LSDV occurs.

There is a paucity of data on the effect of infecting heifers with LSDV at different stages of pregnancy. Anecdotal reports from the field in South Africa, and some case reports, suggest that intra-uterine infection is possible and that infected, non-viable offspring, result [14]. While the occurrence of abortions during LSDV outbreaks have been documented, few studies have reported necropsy findings or virological investigation of aborted foetuses. Despite establishing the source of prolonged seminal shedding of LSDV DNA, no information was collected regarding long-term effects of the testicular and epididymal lesions or their possible resolution. The fate of bulls severely affected by LSD therefore remains speculative. In our experiments we focused primarily on severely affected animals, and therefore the epidemiological significance of those moderately or inapparently affected by LSD, remains unestablished.

The series of studies reported here focused on the bull as a source of LSDV, and transmission routes that would involve LSDV-contaminated semen. Future research 
should also focus on the oocyte and follicular environment of cows infected with LSDV to better illustrate the full reproductive impact of LSDV. Finally, the experimental design of the embryo work in Chapter 3 and 4 did not allow generation of sufficient numbers of embryos to adequately test the IETS washing protocol. Further studies should be undertaken to establish the effectiveness of the IETS washing protocol for removing LSDV.

\subsection{Recommendations}

Chapter 6 investigates the ability of a Neethling-type vaccine to prevent shedding of vaccine strain in semen of vaccinated bulls and the further ability of the immunity to prevent seminal shedding of LSDV following experimental challenge. We were able to show that two vaccinations, given a month apart, provided adequate immunity to prevent shedding of vaccine virus or challenge virus in semen and therefore recommend that, in areas where LSD occurs for the first time, or in naïve populations, this vaccination protocol be followed [15]. It is also our recommendation that all animals at risk of developing LSD be vaccinated from 6 months of age [16]. Yearly booster vaccinations should be given, due to the unknown duration of protection offered by the commercial vaccines currently available [1].

In addition to these recommendations, the current OIE-regulations prescribe vaccination and quarantine of animals from which germplasm is destined for export, should be adhered to [8]. Farmers should be encouraged to separate animals displaying clinical signs from the rest of the herd in an attempt to curtail further spread of disease $[17,18]$. Animals, but especially bulls, that displayed severe clinical signs of LSD, should ideally be slaughtered to reduce the possibility that they may continue to shed LSDV DNA and serve as sources of virus, perpetuating the spread of the disease within a population. When slaughter is not deemed an economically viable option, the double vaccination protocol outlined above, should be followed. It has to be borne in mind that the efficacy of vaccination under such conditions (i.e. in animals in which infection has already been experienced) has not been established. The use of effective insect repellents is encouraged to reduce vector numbers and thereby the likelihood of transmission of the virus within a population [19]. 
Given the underappreciated effects and financial impact of LSDV in subsistence and emerging farming systems, there is a clear need for a dedicated strategy to address this challenge. This is especially important within the South African context, but would also apply to other emerging country agricultural economies. We recommend that training courses should be developed to create awareness of LSD and to sensitise subsistence and emerging farmers to preventive measures that can be taken to lessen the impact of the disease. Focus on clinical signs associated with LSD should be included in the training, and it is critical that the courses should be readily accessible from a language and financial perspective [20]. Retention of the training and penetration of the information in the community can be ensured through regular training opportunities. The existing compulsory community service for newly-graduated veterinarians can greatly assist state veterinary services in providing training to these farming communities. 


\subsection{References}

[1] Tuppurainen E S M, Venter E H, Shisler J L, Gari G, Mekonnen G A, Juleff N, et al. Review: Capripoxvirus Diseases: Current Status and Opportunities for Control. Transbound and Emerging Diseases. 2017. 64:729-45.

[2] Beard P M. Lumpy skin disease: A direct threat to Europe. Veterinary Record. 2016. 178, 557-8.

[3] First cases of lumpy skin disease reported in the EU. The Veterinary record. 2015. 177, 218.

[4] Irons P C, Tuppurainen E S M, Venter E H. Excretion of lumpy skin disease virus in bull semen. Theriogenology. 2005. 63, 1290-7.

[5] Annandale $\mathrm{C} \mathrm{H}$, Irons P C, Bagla V P, Osuagwuh UI, Venter EH. Sites of persistence of lumpy skin disease virus in the genital tract of experimentally infected bulls. Reproduction in Domestic Animals. 2010;45:250-5.

[6] Tuppurainen ESM, Venter EH, Coetzer JAW. The detection of lumpy skin disease virus in samples of experimentally infected cattle using different diagnostic techniques. Onderstepoort Journal of Veterinary Research. 2005;72:153-64.

[7] Annandale $\mathrm{CH}$, Holm DE, Ebersohn K, Venter EH. Seminal transmission of lumpy skin disease virus in heifers. Transboundary and Emerging Diseases. 2014;61:443-8.

[8] OIE. Manual of Diagnostic Tests and Vaccines for Terrestrial animals. Chapter 2414, Lumpy Skin Disease. Paris2010.

[9] Annandale $\mathrm{CH}$, Smuts MP, Ebersohn K, du Plessis L, Thompson PN, Venter EH, et al. Effect of using frozen-thawed bovine semen contaminated with lumpy skin disease virus on in vitro embryo production. Transboundary and Emerging Diseases. 2019;66:1539-47.

[10] Annandale CH, Smuts MP, Ebersohn K, du Plessis L, Venter EH, Stout TAE. Effect of semen processing methods on lumpy skin disease virus status in cryopreserved bull semen. Animal Reproduction Science. 2018;195:24-9.

[11] Babiuk S, Bowden TR, Parkyn G, Dalman B, Manning L, Neufeld J, et al. Quantification of lumpy skin disease virus following experimental infection in cattle. Transboundary and Emerging Diseases. 2008;55:299-307.

[12] Silva N, Solana A, Castro JM. Inactivation of bovine herpesvirus 1 in semen using a hyperimmune egg yolk semen extender. Journal of Veterinary Medicine, Series B. 2000;47:69-75. 


$$
8
$$




\section{Chapter 8}

Nederlandse samevatting 


\subsection{Het belang van LSD in de gezondheid, reproductie en handel van runderen}

Ondanks dat het enkele decennia geleden is geïdentificeerd als een opvallende ziekteverwekker die de gezondheid en productie van runderen in Sub-Sahara Afrika beïnvloedt, trok lumpy skin disease echt de aandacht van een breder veterinair publiek tijdens het tweede decennium van de 21ste eeuw. Dit verhoogde bewustzijn werd veroorzaakt door de snelle verspreiding van de ziekte over het Middellandse Zeegebied tot Turkije, Griekenland, verschillende Balkanlanden en Rusland tijdens deze periode [1]. LSDV werd daarom erkend als een grote bedreiging voor de Europese Unie en er werden verschillende controlemaatregelen genomen om de verspreiding ervan te voorkomen en om te beschermen tegen de mogelijke effecten op de gezondheid en de handel van runderen $[2,3]$.

Dit proefschrift was bedoeld om plaatsen te identificeren met de aanwezigheid van LSDV in het genitale kanaal van experimenteel geïnfecteerde stieren en om het risico van het gebruik van LSDV geïnfecteerd sperma te bepalen. Verdere vragen rijzen tijdens de uitvoering van de eerste experimenten en dit leidde tot daaropvolgende onderzoeken. De snelle verspreiding van LSD door Noord-Afrika, het Middellandse Zeegebied, de Balkanlanden en de Europese Unie heeft de ontwikkeling van de laatste hoofdstukken van het proefschrift verder beïnvloed. Omwille dat de evolutie van het proefschrift van een focus op de stier als de bron van LSDV, naar het potentieel voor overdracht via een IVEP-systeem beschrijft wordt, moet men bedenken dat de bevindingen verschillende implicaties hebben voor verschillende landbouwsystemen. Omdat Zuid-Afrika wordt gekenmerkt door verschillende landbouwsystemen die variëren van zelfvoorzieningsbedrijven tot technologierijke commerciële landbouw, en met een groeiend cohort van opkomende boeren, is het proefschrift samengesteld zodat de verschillende aspecten die belangrijk zijn voor elk van deze landbouwsystemen worden behandeld.

\subsubsection{Bestaans- en opkomende veehouderijsystemen}

De sociaal-economische effecten van LSDV-infectie op het levensonderhoud en opkomende veehouderijsystemen worden niet vaak gewaardeerd en blijven slecht gedefinieerd. In deze situatie, de grootste impact is verminderde productie, dat wordt gemedieerd door de effecten van het virus op levend gewichtstoename, huiden van slechte kwaliteit, slechte melkproductie en 
kleinere oogst van kalveren, waarbij de kalveren langzamer groeien. Omdat stieren in aantal beperkt zijn in deze landbouwsystemen, kunnen orchitis en langdurige zaadafscheiding van het virus na een LSDV-infectie de genetica en het opvolgende inkomen ernstig beïnvloeden, en de gemeenschappelijke praktijk om ernstig getroffen stieren te laten herstellen en opnieuw paren heeft belangrijke epidemiologische implicaties. Het wordt verwacht dat het herstel en hergebruik van ernstig getroffen stieren inderdaad zal leidde tot een verhoogde terugkeer van koeien (d.w.z. verminderde vruchtbaarheid) en kleinere kalvergewassen die zich over het jaar verspreiden. Een dergelijk kalverpatroon heeft vanuit het productieoogpunt verschillende nadelen, omdat het seizoensgebonden regenpatroon in Zuid-Afrika de grasopbrengst en -kwaliteit beïnvloedt en kalveren die geboren worden op momenten dat de graskwaliteit slecht is, nooit herstellen van hun aanvankelijke langzame groeisnelheid. De aanvankelijke slechte groeisnelheid kan worden verbeterd door aanvullende voeding, maar dit is geen haalbare optie in gemeenschappen met beperkte middelen.

Hoofdstuk 2 presenteert daarom een experimentele studie dat ontworpen is om de verdeling van LSDV in fracties van het ejaculaat en de ontwikkeling van laesies in de geslachtsdelen van stieren te onderzoeken. Dit leverde een achtergrond om de aard van langdurig afstoten van LSDV in stierensperma beter te begrijpen, en de gevolgen daarvan, voornamelijk voor zelfvoorzienende en opkomende boeren. In deze fase was het niet bekend of LSDV in sperma geassocieerd was met een specifieke fractie van het ejaculaat of met rode bloedcellen, en de onderliggende mechanismen die melding maakten van het afwerpen van viraal DNA in sperma gedurende maximaal 159 dagen, waren niet onderzocht. De studie toonde aan dat virus en viraal DNA werden afgestoten in alle fracties van het ejaculaat, en het afstoten was niet geassocieerd met de aanwezigheid van bloed in het ejaculaat. Bovendien ontwikkelden zich bij stieren die ernstige klinische symptomen vertoonden, necrotische foci in de testes en epididymiden als gevolg van de virale pathogenese [4]. Immunoperoxidase-kleuring vertoonde een virale associatie met de necrotische foci, wat suggereerde dat de langdurige zaadafscheiding plaatsvond als gevolg van het vrijkomen van viraal DNA uit necrotische gebieden in patent-seminiferische tubuli en de vas deferens. Interessant is, zoals gesuggereerd door Irons [5], dat alle stieren die besmet zijn met LSDV, ongeacht de ernst van de klinische symptomen, op een bepaald moment het virus en het virale DNA in hun sperma afscheiden. De epidemiologische betekenis van deze bevinding is nu niet bekend, maar het was suggereerd dat alle stieren die tijdens een uitbraak aan het virus zijn blootgesteld, zelfs diegenen die geen klinische symptomen vertonen, kunnen als een bron dienen van virussen voor insectenvectoren en bijdragen om de verspreiding van de ziekte binnen een populatie verder te zetten. 
Histopathologisch onderzoek van de aangetaste testikels toonde ernstige en uitgebreide necrose. Dit resulteerde in talloze lege seminiferous tubuli en vernietiging van de epididymale kanalen. Het is nu niet bekend of een stier kan herstellen van dergelijke uitgebreide testiculaire schade, maar veldrapporten lijken aan te geven dat herstel bij sommige individuen voorkomt, maar toch verminderde dagelijkse spermaproductie is aannemelijk. Het is mogelijk dat stieren die langdurige zaadafscheiding van LSDV vertonen, kunnen helpen om het virus in inter-epidemische perioden te handhaven, maar toch dit moeilijk te bevestigen is gezien de schaarste aan gegevens over de duur van de persistentie van de necrotische gebieden in de testes en epididymiden. Aangezien de stieren aantonen dat ze tot 3 weken koorts hebben [6] en de herstelperiode lang is, zal het directe effect van ernstige lumpy skin disease bij zelfvoorzieningsbedrijven en in systemen met een vader, leiden tot moeilijkheden om te paren of zwanger worden en kan economisch verwoestend zijn.

Hoofdstuk 3 presenteert het onderzoek naar de gevolgen van inseminatie met LSDV besmet sperma. Het gebruik van LSDV-spikesperma resulteerde in klinische LSD in enkele vaarzen, wat voor het eerst de zaadoverdracht van LSDV bevestigde [7]. Vanwege de resulterende viremie, of door het direct viruseffect, was het zwangerschapspercentage in het onderzoek laag; dit suggereerde dat lage zwangerschapspercentages zouden worden waargenomen in het levensonderhoud en opkomende veehouderijsystemen bij een uitbraak van LSDV. Uitgebreide necrose van het gehele vrouwelijke voortplantingskanaal (exclusief de eierstokken) werd waargenomen bij koeien die ernstige klinische LSD vertoonden. Het is onwaarschijnlijk dat deze koeien voldoende zouden herstellen om vervolgens een kalf te krijgen of te dragen. Bij licht aangetaste dieren kan de mate van schade aan de uier ook voorkomen dat ze te voet kalveren opbrengen en bijgevolg leid dit tot een verlaagde productie. Deze bevindingen onderstrepen verder de financiële verliezen die kunnen worden verwacht tijdens een LSD-uitbraak.

\subsubsection{Commerciële landbouwsystemen}

De effecten van LSDV zijn niet beperkt tot zelfvoorzieningssystemen en opkomende veehouderijsystemen, maar nemen een andere vorm aan in meer ontwikkelde, commerciële landbouwsystemen. In deze systemen wordt meer aandacht besteed aan productie-efficiëntie, kunstmatige voortplantingstechnologieën en wordt de handel uitgebreid tot het gebruik van bevroren sperma en embryo's, naast de produktie van huiden, melk en vlees. Commerciële 
boeren worden daarom in de eerste plaats getroffen door handelsbeperkingen en, omdat lumpy skin disease een OIE-genoteerde ziekte is, is het in deze setting toepasselijk om de gezondheid en reproductieve effecten van lumpy skin disease te overwegen. De noodzaak om lacunes in onze kennis van de epidemiologie van lumpy skin disease aan te pakken is daarom van even groot belang, ongeacht het betrokken landbouwsysteem.

Als hoofdstuk over vragen die toepasselijk zijn voor beide landbouwsystemen, wijzde hoofdstuk 3 erop dat embryo's met het virus waren besmet, maar dat deze in vivo-geproduceerde embryo's konden gereinigd worden van het virus door de richtlijnen van het IETS wasprotocol te volgen. Bij vaarzen die niet werden gebruikt voor het spoelen van embryo's, werden ernstige klinische symptomen waargenomen in de caudale voortplantingsorganen, wat suggereerde dat de doorspoelmedia van embryo's een lokaal beschermend effect had op de voortplantingsorganen van de embryonale vaarzen. Deze studie toonde daarom aan dat er een risico is in verband met de handel in kiemplasma uit landen waar LSD endemisch is, waardoor de huidige OIE-voorschriften worden ondersteund. De OIE vereist strikte vaccinatie en testen van in quarantaine geplaatste dieren, evenals hun kiemplasma, voordat de handel vanuit LSDV-geïnfecteerde landen wordt toegestaan [8].

Verdere ondersteuning voor de huidige OIE-voorschriften is geproduceerd in hoofdstuk 4 en 5 van dit proefschrift. Onderzoek van het effect van het gebruik van bevroren-ontdooid sperma besmet met LSDV voor in vitro embryoproductie (IVEP), onthulde dat het virus kon worden gedetecteerd in bemestingsmedia en alle embryonische structuren wanneer hoge virusdoses aanwezig waren in het ingevroren-ontdooide sperma [9]. LSDV-virions werden gedetecteerd in gearceerde en niet-gearceerde blastocysten op dag 8 door transmissie-elektronenmicroscopie. Gebruikelijke spermaverwerkingsmethoden waren niet in staat om LSDV uit gecryopreserveerd sperma te verwijderen, met uitzondering van de toevoeging van trypsine aan een Percoll@gradiënt; het succes van deze laatste behandeling ging echter ten koste van de spermakwaliteit en verminderde, maar elimineerde de virale belasting niet [10]. Bovendien werd aangetoond dat LSDV virions ultrastructureel associëren met de spermamembranen. De bevindingen van hoofdstuk 4 en 5 bieden daarom concreet bewijs aan dat het risico van LSDV voor de internationale handel in bevroren en ontdooid sperma, zowel in vivo als wanneer in vitro embryo's worden geproduceerd. 


\subsection{Het effect van de virale dosis LSDV}

Na de conclusie van hoofdstuk 3 kwamen er vragen op over het effect van de LSDV-virale dosis die in deze onderzoeken werd gebruikt. Hoewel een hoge virale dosis nodig kan zijn geweest om ervoor te zorgen dat de ziekte werd geproduceerd, en daarom de experimentele studie van ziekteprogressie en de effecten ervan mogelijk maakt, weerspiegelt het ook mogelijk niet nauwkeurig de natuurlijke infectiedynamiek. Het experimentele ontwerp van beide hoofdstukken 4 en 5 omvatte daarom een hoge dosis, bestaande uit 4 log TCID To $_{50}$ een LSDV-isolaat, en een lagere dosis van $10^{3}$ verdunning van de hoge dosis.

Hoofdstuk 4 bestudeerde het gebruik van bevroren-ontdooid sperma besmet met LSDV op IVEP en had als doel het effect van virusbelasting op het succes van embryoproductie te benadrukken. Het heeft verder onderzoek gedaan naar het bioveiligheidsrisico van LSDV binnen IVEP, rekening houdend met het feit dat embryo's een belangrijk onderdeel vormen van de internationale handel in rundergenetica. De IVEP-resultaten voor eicellen blootgesteld aan bevroren-ontdooid sperma besmet met lage doses (LD) LSDV werden gekenmerkt door lagere splijting en blastocystproductiesnelheden, hoewel het virus of viraal DNA niet kon worden gedetecteerd in de stalen [9]. Wanneer bevroren-ontdooid sperma met een hogere virusdosis (HD) werd gebruikt, de bemestingsmedia en embryonale structuren teste positief door PCR en virusisolatie, wat bewijs leverde voor een virale dosis-gerelateerd effect van LSDV binnen een IVEP-systeem. De afwezigheid van viraal DNA in stalen uit de LD-groep werd toegeschreven aan een lagere Ctwaarde in ingevroren-ontdooide spermastalen, en vermindering van de virale belasting door spermaverwerking en eiceldedudatie tot onder de detectielimiet van de PCR-test.

Een duidelijk verschil werd waargenomen tussen de verwerking van sperma van stalen blootgesteld aan een hoge dosis LSDV en diegenen blootgesteld aan een lage dosis LSDV [10]. Sommige spermaverwerkingsmethoden waren succesvol bij het verlagen van de virale belasting tot onder de detectielimiet van de PCR-test voor de stalen met de lagere virale dosis, maar niet voor de stalen met de hogere dosis. Dit suggereerde dat de virale belasting bij het begin van de spermaverwerking de belangrijkste bepalende factor was van de spermaverwerkingsmethode dat waarschijnlijk het spermastaal van LSDV heeft gereinigd. Meer geavanceerde spermaverwerkingsmethoden kunnen veelbelovend zijn met betrekking tot bio-sanitatie van met LSDV besmet sperma, maar dit moet nog worden onderzocht [12]. Hoge kosten en verminderde spermakwaliteit kunnen hun nut als routinemethoden voor spermaverwerking in KI-centra uitsluiten. 
Het is daarom duidelijk dat de LSDV-virale belasting de reproductieve effecten van het virus beïnvloedt en probeert het risico van het gebruik en de handel van sperma en embryo's van runderen te verminderen. Omdat het feit dat de Ct-waarden van de PCR-amplificatie in deze onderzoeken vergelijkbaar waren met de gerapporteerde waarden voor andere lichaamssecreties [11], en daarom ook vergelijkbaar zijn met niveaus die kunnen worden verwacht met een natuurlijke uitbraak, is de bioveiligheid van het gebruik van sperma dat besmet is met LSDV en het IVEP systeem twijfelachtig, en rechtvaardigt geen herbeoordeling van de bestaande OIEvoorschriften.

\subsection{Klinische syndromen geassocieerd met LSDV-infectie}

In de loop van drie verschillende experimenten $[4,5,7]$, met in totaal 31 runderen en met vergelijkbare materialen en methoden, werden duidelijke klinische syndromen geïdentificeerd. Deze syndromen worden geïllustreerd in figuur 8.1 hieronder.

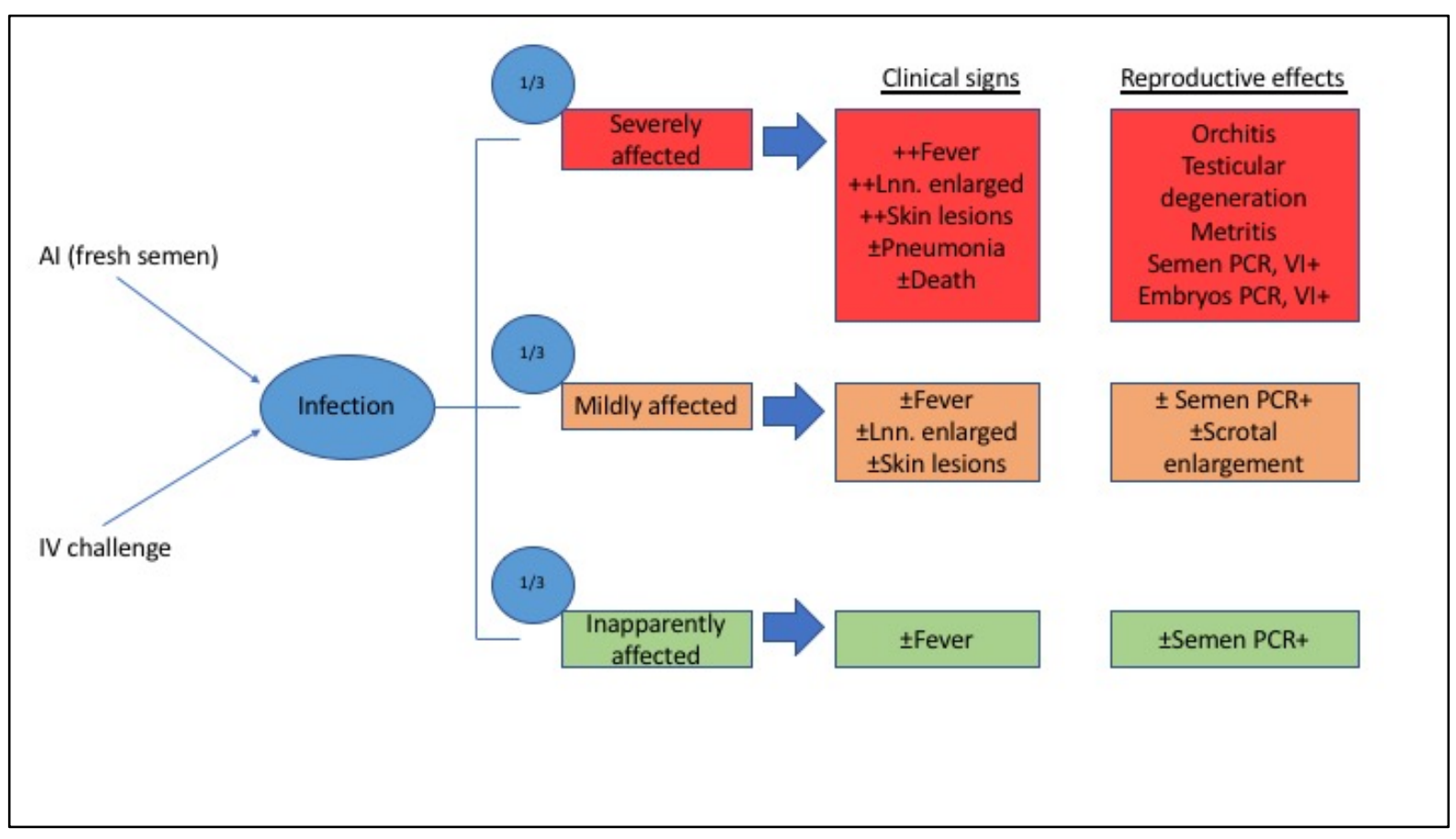

Figuur 8.1: Klinische syndromen geassocieerd met LSDV-infectie 
Onder experimentele omstandigheden, waarbij kunstmatige inseminatie met vers sperma of intraveneuze (IV) toediening met veldstam LSDV werd toegepast, werden de klinische syndromen gelijkmatig over de runderen verspreid. Al naargelang, konden de runderen ingedeeld worden onder een van de drie klinische syndromen:

8.3.1 Ernstig aangetaste LSD: deze dieren vertoonden een gebrek aan eetlust en ernstige koorts (soms boven $40,5^{\circ} \mathrm{C}$ ) die enkele weken duurde, gegeneraliseerde lymfadenopathie gekenmerkt door prescapulaire lymfeklieren die opzwellen tot een diameter groter dan $5 \mathrm{~cm}$, wijdverspreide huidknobbeltjes die gebieden vertonen van vervelling en necrose, en occasionele longontsteking en dood. Vanuit het reproductief oogpunt konden levensvatbare virussen en viraal DNA worden geïdentificeerd in zowel embryo's als sperma, met het laatstgenoemde over een lange periode. De geslachtsorganen van aangetaste dieren vertoonden duidelijke klinische symptomen, variërend van testiculaire degeneratie en begeleidende verminderde scrotumomtrek tot necrotische metritis, cervicitis en mastitis.

8.3.2 Licht getroffen LSD: dieren die in deze categorie vielen, vertoonden lichte koorts die enkele dagen aanhield en oppervlakkige lymfadenopathie. Lymfeklieren werden nooit groter dan $5 \mathrm{~cm}$ en er werden alleen enkele huidknobbels waargenomen, meestal over het scapulaire gebied en op de onderste zijden. Viraal DNA kon in sommige spermastalen worden geïdentificeerd en stieren vertoonden meestal scrotale vergroting, maar waren binnen ongeveer een week weer normaal. In tegenstelling tot spermawinning, die herhaaldelijk gedurende een lange experimentele periode kan worden uitgevoerd, werden embryo's gespoeld op dag 6 of dag 7 na KI, en daarom is het niet bekend of embryo's in een later stadium na infectie met LSDV kunnen besmet wordem in deze categorie van LSD-geïnfecteerde dieren.

8.3.3 Onzichtbare aangetaste LSD: deze categorie dieren vertoonde slechts één of twee dagen koorts en vertoonde geen andere klinische symptomen. Viraal DNA kon slechts in zeer weinig (één of twee) gelegenheden in spermastalen worden geïdentificeerd.

Uit de resultaten van hoofdstuk 4 en 5 blijkt dat de virusbelasting op het moment van infectie een rol kan spelen bij het bepalen in welke klinische syndroomcategorie LSDV-geïnfecteerde runderen kunnen vallen. Dit zou de eerdere bevindingen van Carn and Kitching ondersteunen [13]. 


\subsection{Beperkingen en toekomstige onderzoeksgebieden}

Dit proefschrift is samengesteld uit een reeks experimentele onderzoeken en hoewel ze inzicht gaven in reproductieve aspecten van LSD en de risico's van handel in germplasm in situaties waarin LSDV circuleert, moet de validiteit van onze bevindingen nog worden bevestigd onder veldomstandigheden. Toekomstige studies moeten erop gericht zijn om LSD-uitbraakmateriaal in het veld optimaal te kunnen gebruiken; specifieke aandachtsgebieden moeten de virusbelasting zijn die gepaard gaat met zaadafscheiding, het opvolgen van stieren die ernstige LSD vertonen om de vereiste periode en de mate van herstel vast te stellen en het succes van biosaneringsmethoden die zijn toegepast op sperma dat is gewonnen uit sperma natuurlijk geïnfecteerde stieren.

De gekozen uitdagingen die in onze studies werden gebruikt, waren intraveneuze inenting en kunstmatige inseminatie. Toekomstige studies moeten proberen vast te stellen of infectie via intradermale inoculatie, zoals het geval is voor overdracht via bijtende insecten, tot vergelijkbare bevindingen leidt. Gezien de langere blootstellingsperiode tijdens intradermale inoculatie en de verschillende migratieroute naar de bloedbaan en lymfeklieren, is het denkbaar dat verschillende immunologische paden betrokken kunnen zijn bij bescherming en reactie op verschillende infectieroutes. Dit verantwoordt verder onderzoek, omdat de mate waarin LSDV-zaadafgifte plaatsvindt kan beïnvloed zijn.

$\mathrm{Er}$ is een gebrek aan gegevens over het effect van het infecteren van vaarzen met LSDV in verschillende stadia van de zwangerschap. Anekdotische rapporten uit het veld in Zuid-Afrika en sommige geval rapporten suggereerden dat intra-uteriene infectie mogelijk is en dat geïnfecteerde, niet-levensvatbare nakomelingen het gevolg zijn [14]. Hoewel het voorkomen van abortussen tijdens LSDV-uitbraken is gedocumenteerd, weinig studies hebben melding gemaakt van necropsiebevindingen van virologisch onderzoek van afgebroken foetussen. Ondanks het vaststellen van de bron van langdurige zaadafscheiding van LSDV-DNA, werd geen informatie verzameld over de langetermijneffecten van de testiculaire en epididymale laesies of hun mogelijke resolutie. Het lot van stieren die zwaar getroffen zijn door LSD blijven daarom speculatief. In onze experimenten hebben we ons vooral gericht op ernstig getroffen dieren, en daarom is de epidemiologische betekenis van diegenen die matig of niet duidelijk door LSD zijn aangetast, nog steeds niet vastgesteld. 
De reeks onderzoeken die hier zijn gerapporteerd, waren gericht op de stier als een bron van LSDV en transmissieroutes met LSDV-besmet sperma. Toekomstig onderzoek moet ook gericht worden op de eicel en de folliculaire omgeving van koeien die geïnfecteerd zijn met LSDV om de volledige reproductieve gevolg van LSDV beter te illustreren. Ten slotte liet het experimentele ontwerp van het embryowerk in hoofdstuk 3 en 4 niet toe om voldoende aantallen embryo's te genereren om het IETS-wasprotocol voldoende te testen. Verdere studies moeten worden uitgevoerd om de effectiviteit van het IETS-wasprotocol voor het verwijderen van LSDV vast te stellen.

\subsection{Aanbevelingen}

Hoofdstuk 6 onderzoekt het vermogen van een Neethling-type vaccin om het afstoten van vaccinstam in sperma van gevaccineerde stieren te voorkomen en het verdere vermogen van de immuniteit om zaadafscheiding van LSDV na experimentele uitdaging te voorkomen. We hebben kunnen aantonen dat twee vaccinaties, met een tussenpoos van een maand, voldoende immuniteit boden om het vaccinvirus af te stoten, of om het virus uit te dagen in het sperma, en daarom adviseren dat in gebieden waar LSD voor het eerst voorkomt, of in naïeve populaties, dit vaccinatieprotocol gevolgd wordt [15]. Het is ook onze aanbeveling dat alle dieren die het risico lopen om LSD te ontwikken, te vaccineren vanaf de leeftijd van 6 maanden [16]. Jaarlijkse boostervaccinaties moeten worden gegeven vanwege de onbekende beschermingsduur die nu aangeboden wordt met de beschikbare commerciële vaccins [1].

Naast deze aanbevelingen moeten de huidige OIE-voorschriften voor vaccinatie en quarantaine van dieren waaruit kiemplasma is bestemd voor export, worden aangehouden [8]. Boeren moeten worden aangemoedigd om dieren met klinische symptomen te scheiden van de rest van de kudde in een poging om de verdere verspreiding van ziekten te beperken $[17,18]$. Dieren, maar vooral stieren, die ernstige klinische symptomen van LSD vertoonden, moeten ideaal worden geslacht om de mogelijkheid te verminderen dat ze LSDV-DNA kunnen blijven afwerpen en als virusbronnen dienen, waardoor de verspreiding van de ziekte in een populatie wordt voortgezet. Wanneer slachting niet als een economisch haalbare optie wordt beschouwd, moet het hierboven beschreven dubbele vaccinatieprotocol worden gevolgd. Er moet rekening mee worden gehouden dat de werkzaamheid van vaccinatie onder dergelijke omstandigheden (d.w.z. bij dieren waarin al een infectie is waargenomen) niet is vastgesteld. Het gebruik van effectieve insectenwerende middelen wordt aangemoedigd om het aantal vectoren en daarmee de kans op overdracht van het virus binnen een populatie te verminderen [19]. 
Omdat de ondergewaardeerde effecten en het financiële gevolg van LSDV op zelfvoorzieningssystemen en opkomende landbouwsystemen duidelijk zijn, is er duidelijk behoefte aan een specifieke plan om deze uitdaging aan te gaan. Dit is vooral belangrijk in de ZuidAfrikaanse samenhang, maar zou ook van toepassing zijn op andere landbouweconomieën van opkomende landen. We bevelen aan om trainingscursussen te ontwikkelen om het bewustzijn van LSD te maken en om zelfvoorzienende en opkomende boeren te sensibiliseren voor maatregelen die kunnen worden genomen om de siekte te voorkomen of gevolgen van de ziekte te verminderen. Fixeren op klinische symptomen geassocieerd met LSD moet in de training worden opgenomen en het is van noodzakelijk belang dat de cursussen gemakkelijk toegankelijk zijn vanuit een taal- en financieel perspectief [20]. Behoud van de training en penetratie van de informatie in de gemeenschap kan worden gewaarborgd door regelmatige trainingsmogelijkheden. De bestaande verplichte dienstverlening aan pas afgestudeerde dierenartsen kunnen de veterinaire diensten van de staat enorm helpen bij het geven van training aan deze landbouwgemeenschappen. 
9 


\section{Chapter 9}

Acknowledgements 


\section{There is a lovely road that runs from Ixopo into the hills.}

\section{The hills are grass-covered and rolling, and they are lovely beyond any singing of it.}

Alan Paton Cry, the beloved country

These words have always held a special place in my heart, even though I am not from Ixopo and there aren't many hills around where I live. They speak of what my parents have given me - lovely, grass-covered, rolling hills that lined the road ahead of me. As I started to walk into the hills to create my own Ixopo, I've realised that it has been their unwavering commitment and support to a curious, developing boy that gave me good education and sound judgement with which to remember the rolling hills and travel on that lovely road. I am deeply indebted to them for this, and eternally grateful for their love. However, I am not dedicating this thesis to them! Rather, with my wife Annett, I dedicate it - and my life - to provide for our sons as my parents provided for me.

In reflecting on the road travelled thus far, I wish to sincerely acknowledge a number of people, hopefully not omitting anyone. There is obviously no doubt that I will succeed in exactly that, and for that, I apologise unreservedly. I thank Tom Stout and Estelle Venter for their support and guidance while serving as my promotors. Thanks are also due to my co-workers who enabled me to produce the work and to make it so much better than I would have been able to do on my own. No person taught me more about the wonderous world of IVF than Mario Smuts, and his enthusiasm and loyal friendship carried me when motivation waned. My modest professional skills and knowledge would have been non-existent but for the training received from mentors such as Pete Irons, David Gerber, Johann Nöthling, Johan Terblanche and Martin Schulman. I thank Ellen Goosen and Ester Botha for making "Therios" a home for me. I would be remiss not to mention a few colleagues that have been instrumental in setting up the MOU between the veterinary faculties of Utrecht and Onderstepoort - Albert Cornelissen, Hellen van der Maazen, Nick Kriek, Gerry Swan, Koos Coetzer. Through this memorandum I have met many wonderful colleagues and have broadened my personal and professional horizons. It is my sincere wish that it will continue to be supported by those responsible for it, so that other colleagues can also benefit from it. 
The road travelled became especially lovely when I met Annett while working as a resident. Annett, through and with you I have travelled to Germany, Austria, Italy, the UK and Mozambique and reached the most wonderful destination of all - being your husband and a father to Finn and Ollie. The road with you is lovely beyond any singing of it.

In looking at the end of my road, when it finally comes, I acknowledge my deep dependency on a personal relationship with Jesus Christ, the Author and Perfecter of my faith. 

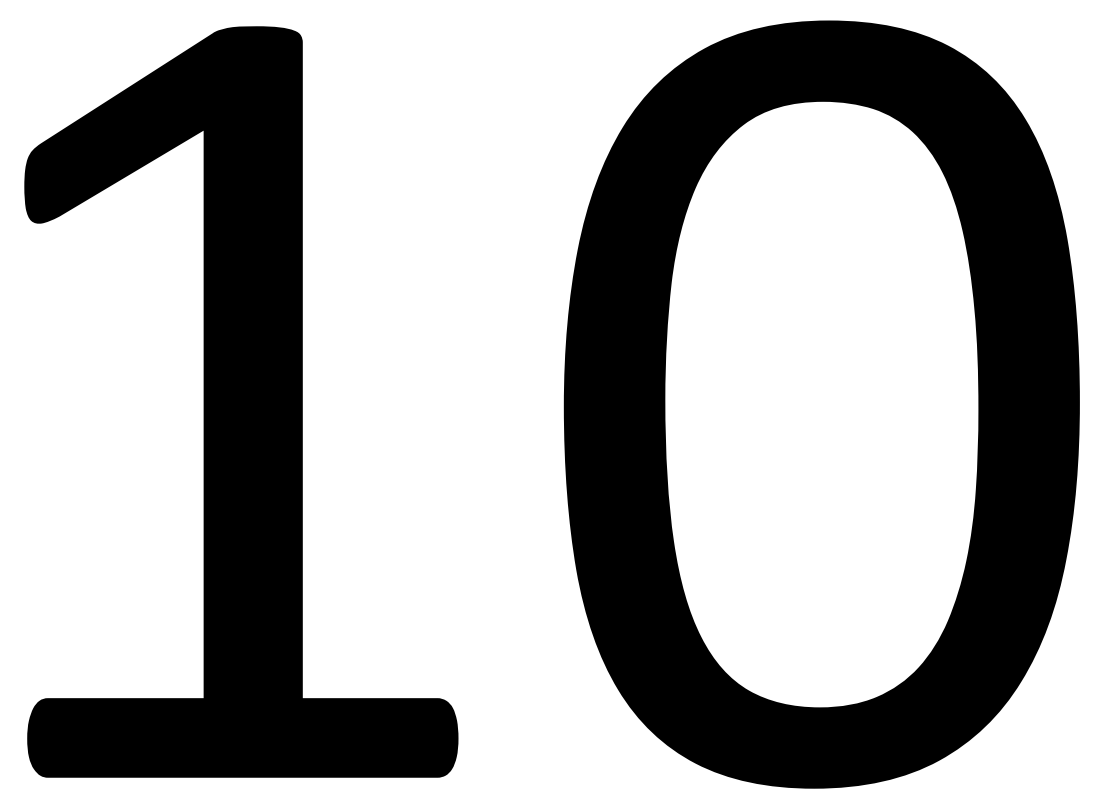


\section{Chapter 10}

Curriculum vitae 
Cornelius Henry Annandale is the eldest son of John and Rita Annandale and was born in Pretoria, South Africa on 23 November 1974. His early life was spent on farms and small holdings around cattle and dogs, and in vegetable fields and crops. He received his primary school education at Laerskool Kreft and his high school education at Hoërskool Kempton Park, both located in Kempton Park on the East Rand of the former Transvaal (now Gauteng). Special memories from these years include many school tours with friends and holidays with family that instilled in him a deep love and appreciation for the rejuvenating power of time spent in the natural beauty of South Africa.

After matriculation in 1992, Henry enrolled for a Bachelor of Commerce at the University of Pretoria and graduated with majors in Accounting, Economics, Private and Commerce Law in 1995. A career change then followed and he was admitted into a Bachelor of Veterinary Science at Onderstepoort in 1997. He followed up the BVSc in 2002 with a BVSc (Hons) in 2004, board certification by the American College of Theriogenologists in 2005, MMedVet (Gyn) in 2007 and an MBA in 2012. He has worked in mixed and small animal private practice, but the majority of his working career has been spent at the Faculty of Veterinary Science, Onderstepoort. This took the form first of Resident, then Lecturer and Senior Lecturer in Theriogenology and finally Associate Professor. The progression through academic ranks took a back seat for a period of more than eight years while he fulfilled the role of Director of Clinical Services of the Onderstepoort Veterinary Academic Hospital.

Highlights of his career includes collaboration with colleagues from the United States to the UK, Germany, the Netherlands, Australia and New Zealand. Animals treated have ranged from million dollar stallions to prize-winning bulls and rams, show dogs and cats, cheetahs, lion, sable, roan, rhinos, elephants and many other African wildlife. At times, even African Rock Pythons! He has had the opportunity to develop a software application to facilitate and manage clinical training and implemented electronic medical records as part of a hospital- and laboratory management software program.

His research career includes publications within the fields of theriogenology, infection control and veterinary education and he has supervised a number of Masters' students. He is regularly consulted by colleagues for his expertise in theriogenology, especially within the fields of ram and bull andrology and breeding soundness. He regularly presents at congresses and CPD events and has penned numerous lay press articles to assist the broader farming community with development and training. 
Henry is married to Annett and the couple have two sons, Finn (9) and Oliver (7). They also count Zulu and Thandi, two Jack Russel Terriers, as part of the family. In his free time, he enjoys amateur astronomy and fly-fishing. 